Synthesis, identification and structure-activity relationship analysis of GATA4 and NKX2-5 protein-protein interaction modulators

\author{
Jumppanen, Antti Mikael
}

2019-09-12

Jumppanen , A M , Kinnunen , S M , Välimäki , M J , Talman , V , Auno , S , Bruun , T , Boije af Gennäs , G , Xhaard , H G M , Aumuller , I B , Ruskoaho , H \& Yli-Kauhaluoma , J 2019 , ' Synthesis, identification and structure-activity relationship analysis of GATA4 and NKX2-5 protein-protein interaction modulators ', Journal of Medicinal Chemistry , vol. 62 , no. 17 , pp. 8284-8310 . https://doi.org/10.1021/acs.jmedchem.9b01086

http://hdl.handle.net/10138/305989

https://doi.org/10.1021/acs.jmedchem.9b01086

cc_by

publishedVersion

Downloaded from Helda, University of Helsinki institutional repository.

This is an electronic reprint of the original article.

This reprint may differ from the original in pagination and typographic detail.

Please cite the original version. 


\section{Synthesis, Identification, and Structure-Activity Relationship Analysis of GATA4 and NKX2-5 Protein-Protein Interaction Modulators}

Mikael Jumppanen, ${ }^{\dagger}$ Sini M. Kinnunen, ${ }^{\ddagger}$ Mika J. Välimäki, ${ }^{\ddagger 0}$ Virpi Talman, ${ }^{\ddagger}{ }^{\ddagger}$ Samuli Auno, ${ }^{\dagger \oplus}$ Tanja Bruun, ${ }^{\dagger,}$ Gustav Boije af Gennäs, ${ }^{\dagger}$ Henri Xhaard, ${ }^{\dagger}{ }^{\dagger}$ Ingo B. Aumüller, ${ }^{\dagger}$ Heikki Ruskoaho, ${ }^{\ddagger}$ and Jari Yli-Kauhaluoma* ${ }^{*} \dagger$ (i)

${ }^{\dagger}$ Drug Research Program, Division of Pharmaceutical Chemistry and Technology, Faculty of Pharmacy, and ${ }^{\ddagger}$ Drug Research Program, Division of Pharmacology and Pharmacotherapy, University of Helsinki, Viikinkaari 5 E (P.O. Box 56), Helsinki FI-00014, Finland

${ }^{\S}$ Imperial College London, Imperial Centre for Translational and Experimental Medicine, National Heart and Lung Institute, Du Cane Road, London W12 0NN, United Kingdom

Supporting Information

ABSTRACT: Transcription factors GATA4 and NKX2-5 directly interact and synergistically activate several cardiac genes and stretch-induced cardiomyocyte hypertrophy. Previously, we identified phenylisoxazole carboxamide $\mathbf{1}$ as a hit compound, which inhibited the GATA4-NKX2-5 transcriptional synergy. Here, the chemical space around the molecular structure of $\mathbf{1}$ was explored by synthesizing and characterizing 220 derivatives and structurally related compounds. In addition to the synergistic transcriptional activation, selected compounds were evaluated for their effects on transcriptional activities of GATA4 and NKX2-5 individually as well as potential cytotoxicity. The structureactivity relationship (SAR) analysis revealed that the aromatic isoxazole substituent in the southern part regulates the inhibition of GATA4-NKX2-5 transcriptional synergy. Moreover, inhibition of GATA4 transcriptional activity correlated with the reduced cell viability. In summary, comprehensive SAR analysis accompanied by data analysis successfully identified potent and selective inhibitors of GATA4-NKX2-5 transcriptional synergy and revealed structural features important for it.

\section{INTRODUCTION}

Protein-protein interactions (PPIs) are critical regulatory events in physiology and diseases, and they represent an attractive target for pharmacological interventions. ${ }^{1}$ However, targeting PPIs with small molecules is challenging due to the large surface area involved in protein-protein binding and the lack of clear binding pockets for small molecules at many protein-protein interfaces. Nevertheless, the number of successful examples of small molecule modulators of PPIs has been growing, ${ }^{1,2}$ and Lawson et al. recently concluded that small molecules provide significant opportunities for allosteric modulation of PPIs. ${ }^{3}$ Transcription factors are the fundamental regulators of gene expression, and their PPIs are of pivotal importance in the regulation of biological systems. ${ }^{4}$ The GATA family of transcription factors consists of six proteins (GATA1-6), which are involved in a variety of physiological and pathological processes. ${ }^{5-7}$ GATA1-3 are required for differentiation of mesoderm and ectoderm-derived tissues, whereas GATA4-6 are implicated in the development and differentiation of endoderm- and mesoderm-derived tissues such as induction of differentiation of embryonic stem cells and cardiovascular embryogenesis. ${ }^{6}$ In the developing heart, GATA4 is one of the earliest-expressed transcription factors ${ }^{8}$ and is essential for normal cardiac development. ${ }^{9-12}$ In the postnatal heart, GATA4 acts as a critical regulator of hormone response and mechanical stress ${ }^{13-16}$ as well as cardiac repair and regeneration. ${ }^{17-20}$

GATA4 actions involve combinatorial interactions with a number of other nuclear proteins, reinforcing their activity and tissue specificity. ${ }^{5-7}$ For example, functional cardiomyocytes can be directly induced from fibroblasts by a combination of three cardiac transcription factors, GATA4, MEF2C, and TBX5, in vitro and in vivo. ${ }^{21,22}$ Most of the PPIs occur through the C-terminal zinc finger, which also mediates DNA binding and is highly conserved throughout the GATA family. GATA4 regulates myocardial gene expression by interacting with different cardiac specific transcription factors, such as

Received: July 5, 2019

Published: August 20, 2019 
NKX2-5, NFAT, and MEF2. ${ }^{5-7}$ NKX2-5, a member of the evolutionary conserved NK family of homeobox proteins, is a critical GATA4 cofactor and essential for heart development. ${ }^{23-25}$ GATA4 and NKX2-5 directly interact and synergistically activate several genes including those encoding atrial natriuretic peptide (ANP) and B-type natriuretic peptide (BNP). ${ }^{7,26}$ Mutational studies have shown that the tandem GATA consensus sites of the proximal promoter in combination with an NKX2-5 binding element are important for the stretch-activated BNP transcription. ${ }^{27}$ As the precise balance of GATA4-NKX2-5 interaction is essential for mechanical stretch-induced cardiomyocyte hypertrophy, the functional modulation of their interaction could present a novel approach for cardiac repair under pathophysiological conditions.

We have previously shown that single point mutations can interfere with GATA4 and NKX2-5 interaction, ${ }^{28}$ implicating that this PPI is targetable by small molecules to achieve direct inhibition, activation, or allosteric modulation. Recently, we reported the identification of several compounds that affect the transcriptional synergy of GATA4 and NKX2-5. ${ }^{29,30}$ In addition, we have shown that a small molecule inhibitor of GATA4-NKX2-5 transcriptional synergy reduces cardiomyocyte hypertrophic response in vitro, ameliorates hypertrophic signaling in vivo, and improves cardiac function in vivo in experimental models of myocardial infarction and hypertension. $^{29,31,32}$ These studies led to the identification of compounds 1-3 (Figure 1), which either increase (2) or

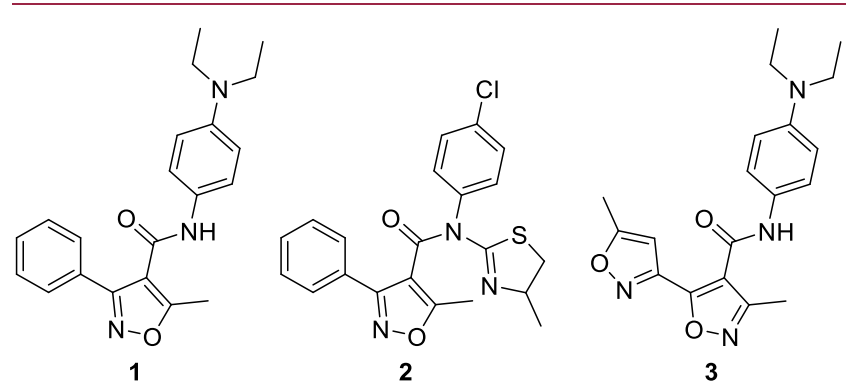

Figure 1. Representative examples of the previously reported modulators of GATA4-NKX2-5 transcriptional synergy. ${ }^{29}$ Compounds 1 and 3 inhibit and compound 2 enhances transcriptional synergy of GATA4 and NKX2-5.

inhibit (1 or 3 ) the transcriptional synergy of GATA4 and NKX2-5. ${ }^{29}$ Our aim in this study was to optimize the original isoxazole hit compound $\mathbf{1}$ by means of synthesis and biological investigation of 220 structurally related compounds with modified or alternative northern, central, and southern parts (Figure 2). Additionally, this structure-activity relationship (SAR) analysis was augmented by 29 commercial and 8 previously published compounds ${ }^{33}$ that were tested with a luciferase reporter assay to examine their effects on the transcriptional synergy of GATA4 and NKX2-5. The most potent compounds were also tested independently in luciferase reporter assays for NKX2-5 and GATA4 activity. Furthermore, toxicity of the selected compounds was studied with 3-(4,5dimethylthiazol-2-yl)-2,5-diphenyltetrazolium (MTT) and lactate dehydrogenase $(\mathrm{LDH})$ assays in the COS-1 cell line.

\section{RESULTS}

Chemistry. Synthesis of Compounds. To gain information on the chemical space of the hit compound $\mathbf{1}$ in regard to the ability of such molecules to inhibit GATA4-NKX2-5 transcriptional synergy, we synthesized 220 structurally related compounds. For a simplified view, we divided the chemical structure 1 into three sections, that is, northern, central, and southern parts (Figure 2). The original central amide linker in 1 was replaced with other linkers, such as alkyl, amino, inverse amide, imino, ether, and thioamide linkers. The alternative southern parts comprise structural changes of the isoxazole substituents ( $\mathrm{Ph}$ or $\mathrm{Me}$ ), scaffold hopping, as well as exploration of other heterocycles as surrogates of the original isoxazole ring. In the northern part, we mainly experimented with substituted phenyl moieties in the para position. A few compounds comprised of heterocycles in the northern part and some compounds devoid of a central or northern part were prepared.

Northern Part. The synthesis of selected derivatives with alternative northern parts is shown in Scheme 1. The amides $4 a-k$ were obtained from various amines $5 \mathbf{a}-\mathbf{k}$ and 5-methyl3-phenylisoxazole-4-carboxylic acid $\mathbf{6}$ in the presence of $N, N, N^{\prime}, N^{\prime}$-tetramethyl-O-(1H-benzotriazol-1-yl)uronium hexafluorophosphate (HBTU), or in some cases $O$-(7-azabenzotriazol-1-yl)-N,N,N,$N^{\prime}$-tetramethyluronium hexafluorophosphate (HATU) as a coupling agent and Hünig's base (DIPEA). The quaternary ammonium salt 7 was obtained by alkylating compound $\mathbf{4 i}$ with iodomethane in methanol under microwave irradiation. The nitro derivative 8 was obtained from compound $\mathbf{5 i}$ with $\mathrm{NOBF}_{4}$ in acetonitrile. The reductive treatment of compound $\mathbf{8}$ with zinc in an equimixture of acetic acid and methanol produced the corresponding amine 9. The esters $10 a-d$ were then prepared from the methyl benzoate $\mathbf{1 1}$ by a base-assisted ester hydrolysis followed by alkylation of the resulting benzoic acid derivative $\mathbf{1 2}$ with alkyl halides in the presence of $\mathrm{K}_{2} \mathrm{CO}_{3}$ in $\mathrm{N}, \mathrm{N}$-dimethylformamide (DMF).

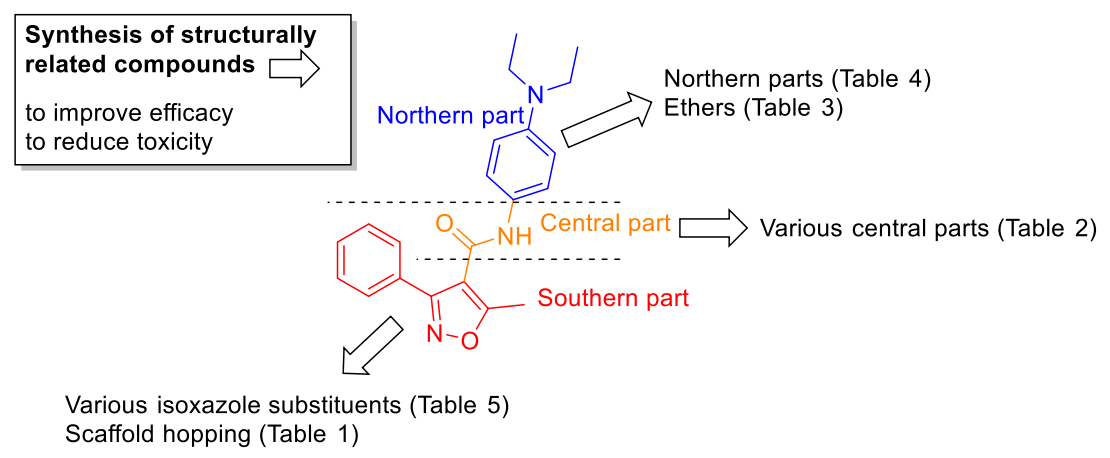

Figure 2. Synthesis strategy for structural modifications of compound $\mathbf{1}$. 
Scheme 1. Synthesis of the Compounds with Different Northern Parts ${ }^{a}$

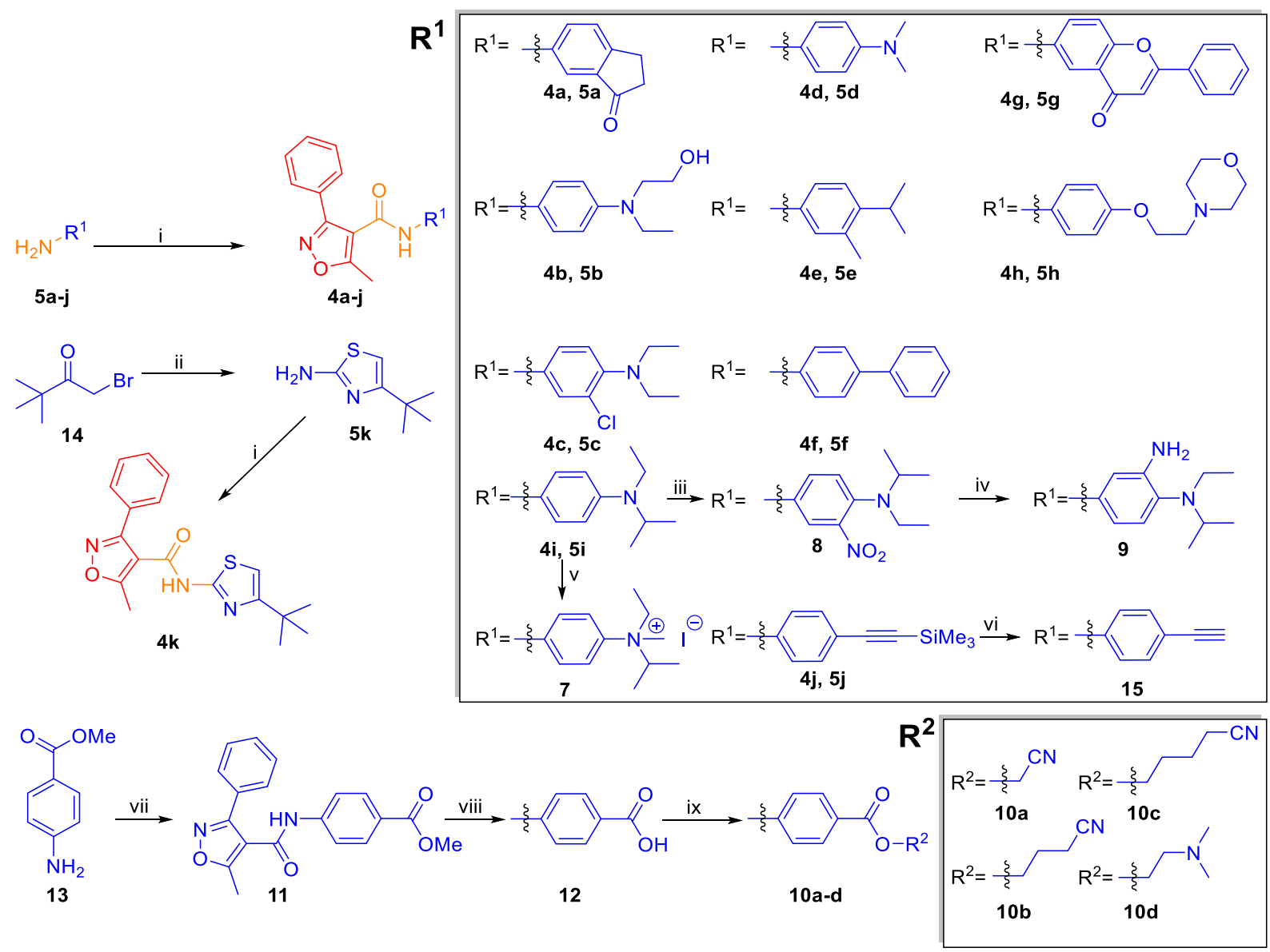

${ }^{a}$ Reagents and conditions: (i) 5-methyl-3-phenylisoxazole-4-carboxylic acid (6), HBTU, DIPEA, DMF, rt, $1-2 \mathrm{~d}$; (ii) EtOH, mw (100 ${ }^{\circ} \mathrm{C}, 30$ min); (iii) $\mathrm{NOBF}_{4}, \mathrm{MeCN}, 0{ }^{\circ} \mathrm{C}, 2 \mathrm{~h}$; (iv) $\mathrm{Zn}, \mathrm{AcOH} / \mathrm{MeOH}(1: 1)$, rt, overnight; (v) MeI, MeOH, mw (100 ${ }^{\circ} \mathrm{C}, 8 \mathrm{~h}$ ); (vi) $t$-BuBr, TBAF, THF; (vii) 6, $(\mathrm{COCl})_{2}, \mathrm{DMAP}$, py, rt, $3 \mathrm{~d}$; (viii) $\mathrm{LiOH} \cdot \mathrm{H}_{2} \mathrm{O}, \mathrm{THF} / \mathrm{MeOH} / \mathrm{H}_{2} \mathrm{O}(1+1+1)$, rt, $2 \mathrm{~d}$; (ix) $10 \mathrm{a}-\mathrm{c}, \mathrm{R}^{2} \mathrm{Br}, \mathrm{K}_{2} \mathrm{CO}_{3}, \mathrm{DMF}, \mathrm{rt}, 1-4 \mathrm{~d}$; 10d, $\mathrm{HO}\left(\mathrm{CH}_{2}\right)_{2} \mathrm{~N}\left(\mathrm{CH}_{3}\right)_{2}, \mathrm{HBTU}$, DIPEA, DMF, rt, $3 \mathrm{~d}$.

Compound 11 was prepared via acid chloride of $\mathbf{6}$, generated with oxalyl chloride in the presence of catalytic amount of DMF. 4-(tert-Butyl)thiazol-2-amine 5k was synthesized by letting thiourea and 1-bromopinacolone 14 react in ethanol under microwave irradiation at $120{ }^{\circ} \mathrm{C}^{34}$ Compound 15 was prepared from the corresponding ethynyl(trimethylsilyl) derivative $4 \mathbf{j}$ in the presence of tert-butyl bromide and $n$ tetrabutylammonium fluoride (TBAF) in THF.

Central Part. The investigation of the central part was important to evaluate the role of changes in hydrogen-bond accepting or donating properties of the central linker, the importance of its electrostatic effects, and aspects of flexibility in this molecular region. The central part of the hit compound 1 (an amide linker) has both hydrogen-bond donating and accepting properties. It can be considered as relatively polar and due to the delocalized lone pair of nitrogen electrons as quite rigid. Selected compounds are presented in Schemes 2 and 3. The acetamide derivative $\mathbf{1 6}$ was prepared from $\mathrm{N}, \mathrm{N}$ diethyl-p-phenylenediamine 17 and 5-methyl-3-phenylisoxazole-4-carbaldehyde 18 via the intermediate imine 19. The imine 19 was subsequently reduced to the corresponding amine 20 with sodium borohydride, followed by treatment with acetyl chloride in pyridine. The sulfonamide 21 was obtained from a reaction between 5-methyl-3-phenylisoxazole4-sulfonyl chloride 22 and diamine 17 in pyridine. Thioamide
23 was obtained by reacting 1 with Lawesson's reagent and could be derivatized by base treatment $\left(\mathrm{Li}_{2} \mathrm{CO}_{3}\right.$ and $\left.\mathrm{NaH}\right)$ and a reaction with alkyl halides to give $S$-alkylated derivatives 24a,b. The alkylated amides $25 \mathbf{a}-$ c were obtained from 1 by deprotonation with sodium hydride and subsequent alkylation, and the thioamide analogue $\mathbf{2 6}$, in turn, was obtained from the $\mathrm{N}$-methylated amide 25a and Lawesson's reagent.

The inverse amide 27 was prepared from 5-methyl-3phenylisoxazol-4-amine 28 and 4-(diethylamino)benzoic acid 29. Because of the poor reactivity of the electron-rich carboxyl group of 29 (electron-donating effects of its para substituent), a reaction sequence via the acid chloride (generated with oxalyl chloride and DMF, cat.) was given preference over the generally applied HBTU-mediated coupling. The N,Ndisubstituted amines $\mathbf{3 0 a}-\mathbf{d}$ were prepared through the initial imine intermediate 31 of the reaction between 4(diethylamino)benzaldehyde 32 and isoxazolylamine 28. The carbon-nitrogen double bond of the imine was reduced with $\mathrm{NaBH}_{4}$ to give the corresponding secondary amine 33, followed by a reaction with an appropriate reagent (alkyl halides, anhydride, or isocyanate) under basic conditions.

Central Part: Ethers. The synthesis of the compounds $34 a-$ e, 35a-e, and 36a,b with an ether linkage in the central part is presented in Scheme 3. First, the carboxylic acid $\mathbf{6}$ was reduced to the corresponding primary alcohol 37 with borane-THF 
Scheme 2. Selected Compounds with Different Central Parts ${ }^{a}$

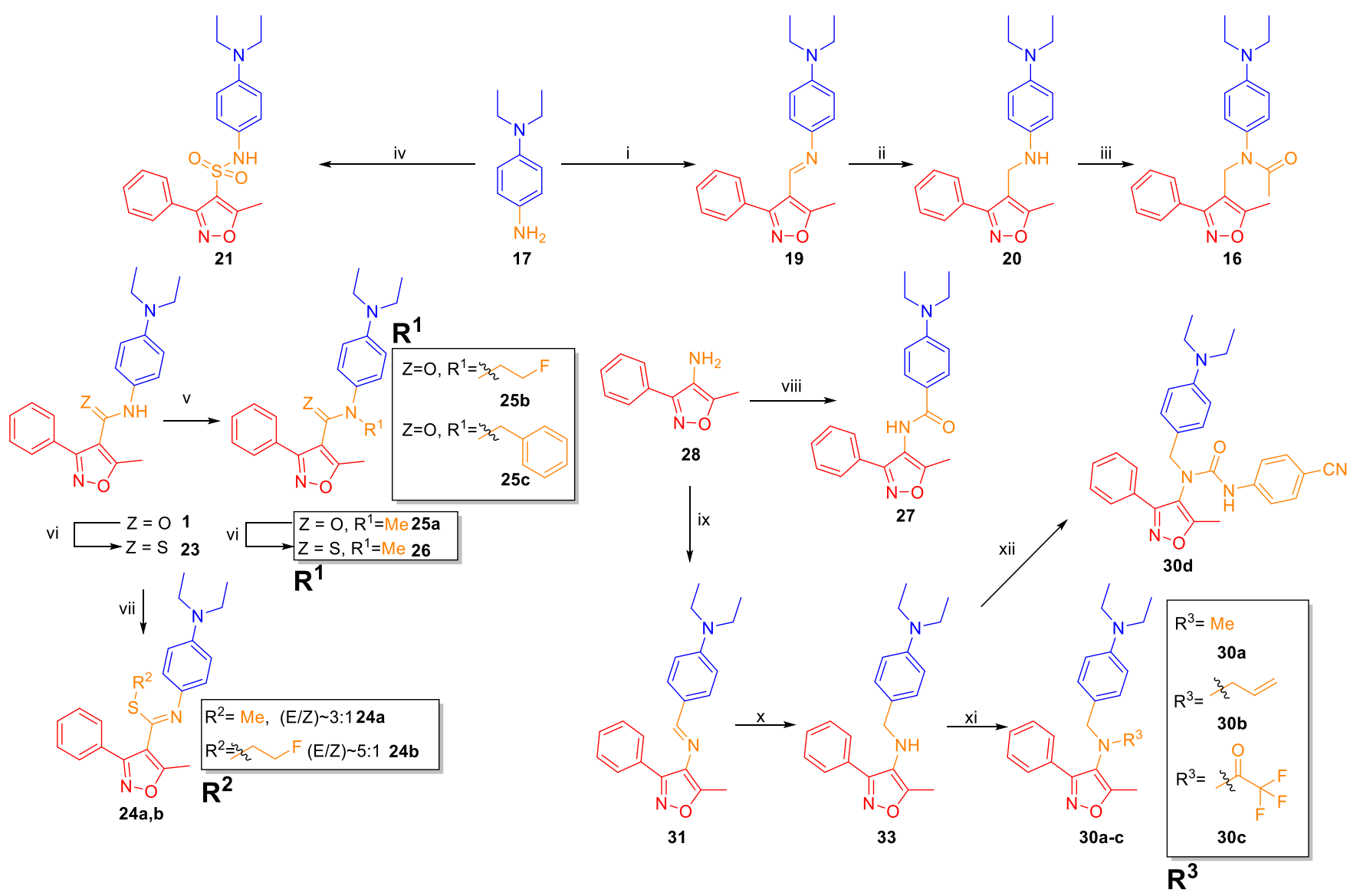

${ }^{a}$ Reagents and conditions: (i) 5-methyl-3-phenylisoxazole-4-carbaldehyde (18), $\mathrm{AcOH}, \mathrm{Na}_{2} \mathrm{SO}_{4}$ (anhydr.), THF, rt, $5 \mathrm{~h}$; (ii) $\mathrm{NaBH}$, THF, $\mathrm{MeOH}$, rt, overnight; (iii) $\mathrm{AcCl}$, py, rt, $4 \mathrm{~d}$; (iv) 5-methyl-3-phenylisoxazole-4-sulfonyl chloride (22), py, $0{ }^{\circ} \mathrm{C} \rightarrow \mathrm{rt}$, overnight; (v) (1) NaH, DMF, $0{ }^{\circ} \mathrm{C}$, 1-2 h, (2) $\mathrm{R}^{1} \mathrm{Br}$ or $\mathrm{R}^{1} \mathrm{I}, 0{ }^{\circ} \mathrm{C} \rightarrow \mathrm{rt}, 1-4 \mathrm{~d}$; (vi) Lawesson's reagent, PhMe, $110{ }^{\circ} \mathrm{C}, 6-8 \mathrm{~h}$; (vii) 24a, $\mathrm{MeI}, \mathrm{Li}_{2} \mathrm{CO}_{3}, \mathrm{MeCN} / \mathrm{DMSO}, 38{ }^{\circ} \mathrm{C}$, overnight; 24b, (1) NaH, DMF, $0{ }^{\circ} \mathrm{C}, 2 \mathrm{~h},(2) \mathrm{Br}\left(\mathrm{CH}_{2}\right)_{2} \mathrm{~F}, \mathrm{rt}, 3 \mathrm{~d}$; (viii) (1) 4-(diethylamino)benzoic acid (29), (COCl) $)_{2}, \mathrm{cat} . \mathrm{DMF}, \mathrm{DCM}, \mathrm{rt}, 2 \mathrm{~h}$, (2) 28, py, rt, overnight; (ix) 4-(diethylamino)benzaldehyde (32), $\mathrm{AcOH}, \mathrm{Na}_{2} \mathrm{SO}_{4}$ (anhydr.), $\mathrm{PhMe}$, rt, overnight; $(\mathrm{x}) \mathrm{NaBH}, \mathrm{MeOH} / \mathrm{THF}, \mathrm{rt}, 2$ d; (xi) 30a, MeI, $\mathrm{Cs}_{2} \mathrm{CO}_{3}, \mathrm{DMF}, \mathrm{rt}, 3 \mathrm{~d}$; 30b, allyl iodide, DMF, rt, 3 d; 30c, or TFAA, DMAP, py, rt, 2 d; (xii) 4-isocyanatobenzonitrile, THF, rt, 4 d.

complex. Using the Mitsunobu reaction with triphenylphosphine, diisopropyl azodicarboxylate (DIAD), and suitable phenols, compound 37 was converted to the derivatives 34a, $34 b$, and 34c. The ketone 34a was reduced with $\mathrm{NaBH}_{4}$ in the presence of diethylamine to the corresponding alcohol 34d, which in turn could be alkylated with iodomethane after deprotonation with $\mathrm{NaH}$ to give the ether compound 34e. Furthermore, the ester-substituted northern part 34c was hydrolyzed with $\mathrm{LiOH} \cdot \mathrm{H}_{2} \mathrm{O}$ to give the corresponding benzoic acid 38, which was coupled with five other alcohols and two amines to give the esters $35 \mathbf{a}-\mathbf{e}$ and amides $36 \mathbf{a}, \mathbf{b}$, respectively. Except for the synthesis of $35 \mathbf{b}$, all of these coupling reactions were performed with HBTU, employing amines and alcohols. In contrast, compound $\mathbf{3 5 b}$ was prepared by a nucleophilic substitution of 4-bromobutanenitrile under basic conditions $\left(\mathrm{K}_{2} \mathrm{CO}_{3}\right)$.

Southern Part. The synthetic routes to isoxazoles with substituted phenyl moieties, heteroaryl residues, or ethyl substituent in the 3 position (39a-o and 40) are described in Scheme 4. The amide couplings of the building blocks 41ao and the phenylenediamines 17 and 42, respectively, were performed with HBTU or HATU. The bromophenyl derivative $39 \mathbf{i}$ was further converted to the biphenyl $39 \mathbf{j}$ via tetrakis(triphenylphosphine)palladium(0)-catalyzed Suzuki reaction. In addition, Scheme 4 presents syntheses for the isoxazolecarboxylic acid building blocks that were not commercially available (41f and 411-p). The carboxylic acids $411-\mathbf{p}$ were synthesized via 1,3-dipolar cycloaddition reactions between nitrile oxides and ethyl 2-butynoate. The nitrile oxide intermediates were generated from the corresponding oximes $431-p$ that were, in turn, prepared from the respective aromatic aldehydes 441-p. The 1,3-dipolar additions were mediated by (diacetoxyiodo)benzene (DIB) ${ }^{35}$ or alternatively by Oxone. ${ }^{36}$ The resulting isoxazole esters 451-p were hydrolyzed with either $\mathrm{LiOH} \cdot \mathrm{H}_{2} \mathrm{O}$ or $\mathrm{NaOH}$ to produce the intermediate carboxylic acids 411-p. Carboxylic acid 41f was prepared from the 3-(2,6-dichlorophenyl)-5methylisoxazole-4-carboxylic acid 41e via nitration of the phenyl ring by $\mathrm{HNO}_{3}$ in the presence of $\mathrm{H}_{2} \mathrm{SO}_{4}$.

Further, we embarked on identifying the surrogates of isoxazole ring in the southern part. The carboxyl scaffolds $46 a-a c$ were either commercially available or synthesized. Synthesis of the triazole scaffolds is presented in the Supporting Information. Carboxylic acids $46 a-a c$ were linked to the northern part $\mathbf{1 7}$ via a HBTU or HATU-mediated amide 
Scheme 3. Synthesis of Ethers ${ }^{a}$

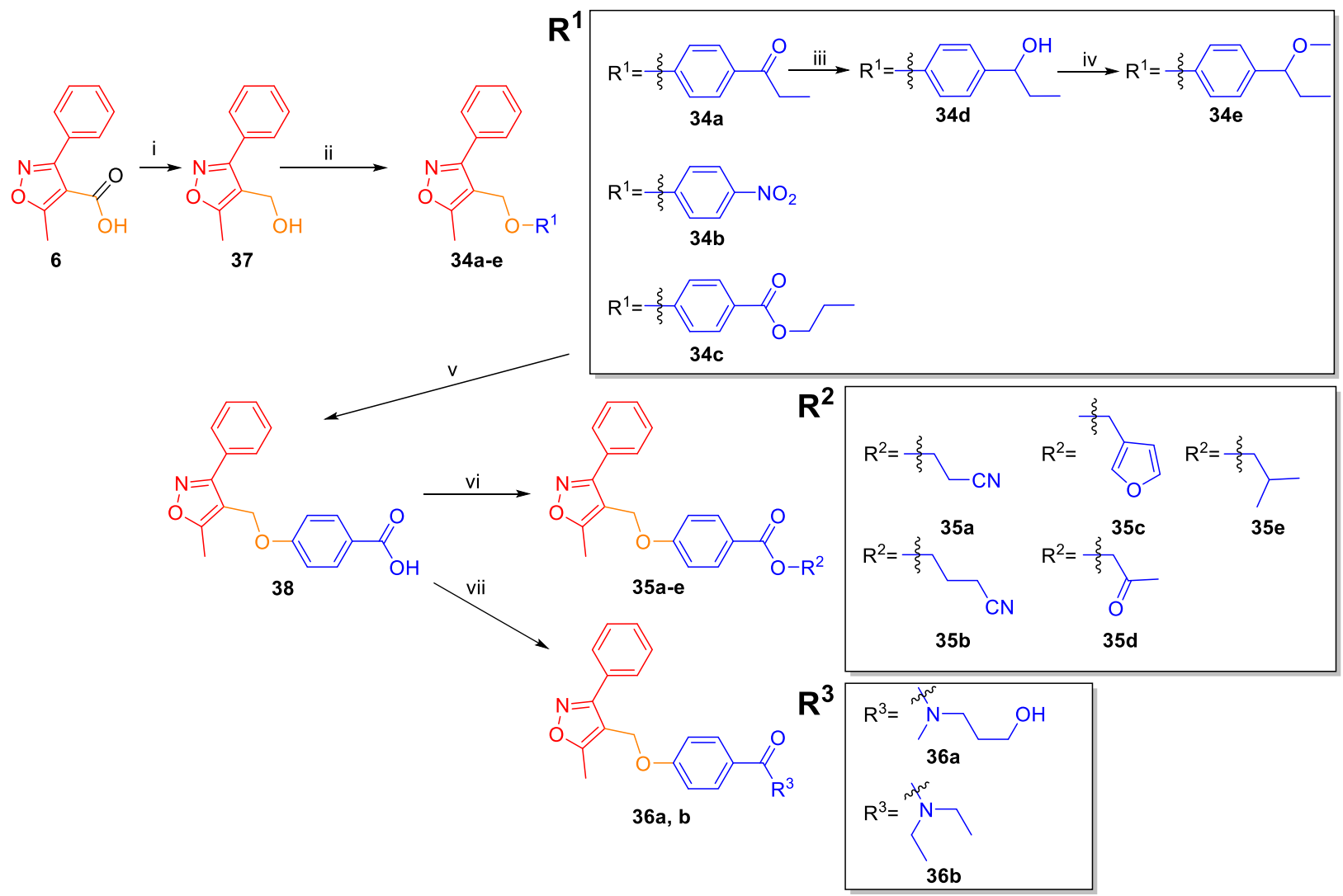

${ }^{a}$ Reagents and conditions: (i) $\mathrm{BH}_{3}-\mathrm{THF}$, THF, $0{ }^{\circ} \mathrm{C} \rightarrow \mathrm{rt}, 7 \mathrm{~d}$; (ii) $\mathrm{R}^{1} \mathrm{OH}, \mathrm{Ph}_{3} \mathrm{P}, \mathrm{DIAD}, \mathrm{THF}, 0{ }^{\circ} \mathrm{C} \rightarrow \mathrm{rt}$, overnight; (iii) $\mathrm{NaBH}_{4}, \mathrm{Et}_{2} \mathrm{NH}, \mathrm{EtOH}$, $35-40{ }^{\circ} \mathrm{C}, 3 \mathrm{~d}$; (iv) (1) $\mathrm{NaH}\left(60 \mathrm{w} / \mathrm{w} \%\right.$, mineral oil), DMF, $0{ }^{\circ} \mathrm{C}, 45 \mathrm{~min},(2) \mathrm{MeI}, 0{ }^{\circ} \mathrm{C} \rightarrow \mathrm{rt}$, overnight; $(\mathrm{v}) \mathrm{LiOH} \cdot \mathrm{H}_{2} \mathrm{O}, \mathrm{THF} / \mathrm{MeOH} / \mathrm{H}_{2} \mathrm{O}$ $(1+1+1)$, rt, overnight; (vi) 35a and 35c-e, $\mathrm{R}^{2} \mathrm{OH}, \mathrm{HBTU}$, DIPEA, DMF, rt, 2-4 d; 35b, 4-bromobutanenitrile, $\mathrm{K}_{2} \mathrm{CO}_{3}, \mathrm{DMF} \mathrm{rt}, 4 \mathrm{~d}$; (vii) $\mathrm{R}^{3} \mathrm{H}$ (sec. amine), HBTU, DIPEA, DMF, rt, overnight.

coupling in the presence of DIPEA (Table 1) to give the amides $47 \mathrm{a}-\mathrm{ac}$ for subsequent biological studies.

Surprisingly, our attempt to extend the isoxazole core from the 5-position via substitution with bromine followed by an amide coupling led to a spontaneous formation of a small amount of imine 48 in the absence of an oxidizing reagent (Scheme 5). 5-Methyl-3-phenylisoxazole-4-carboxylic acid 6 was brominated in the presence of $\mathrm{N}$-bromosuccinimide (NBS) and benzoylperoxide. The attempt to couple the formed crude product 49 with $N, N$-diethyl-p-phenylenediamine hydrochloride 50 via HBTU and DIPEA gave a small amount (3\% yield over two steps) of the imine 48 . We confirmed this finding by synthesizing the imine derivative $\mathbf{5 1}$ without coupling reagents under microwave irradiation (120 ${ }^{\circ} \mathrm{C}, 30 \mathrm{~min}$ ). Imine $\mathbf{5 1}$ was synthesized from methyl 5-methyl3-phenylisoxazole-4-carboxylate $\mathbf{5 2}$ via bromide intermediate 53. A possible explanation for the formation of an imine could be an autoxidation of the corresponding amine obtained by a nucleophilic substitution of bromide. Autoxidations of amines of highly conjugated compounds have been reported previously. $^{37}$

Biology. Luciferase Reporter Assays. To screen compounds for the GATA4-NKX2-5 interaction, we have developed a luciferase reporter assay based on their property to activate gene transcription synergistically through the NKX2-5 binding site on DNA. ${ }^{28}$ In this assay, we transfected mammalian COS-1 cells with protein expression vectors for GATA4 and NKX2-5 proteins together with artificial luciferase reporter vector containing three high affinity binding sites for NKX2-5 (NKE). As shown in Figure 3A, NKX2-5 activates the luciferase reporter vector, and together with GATA4 the activation is synergistic, while GATA4 alone has only a minor effect. All 257 compounds were tested in two concentrations, 3 and $10 \mu \mathrm{M}$. Compounds either inhibited, enhanced, or had no effect on the GATA4-NKX2-5 transcriptional synergy. To investigate the selectivity of the active compounds, we tested their effects on NKX2-5 transcriptional activity by using the same luciferase reporter vector as in transcriptional synergy assay with three NKE sites (Figure 3B). Furthermore, we used GATA luciferase reporter assay to examine if compounds have an effect on GATA4 transcriptional activity. In this assay, we cotransfected the cells with a GATA4 protein expression vector and a reporter vector with tandem GATA4 binding sites (Figure 3C). Previously we have reported that compound 1 inhibited the GATA4-NKX2-5 transcriptional synergy at micromolar concentrations $\left(\mathrm{IC}_{50}=3 \mu \mathrm{M}\right){ }^{29}$ However, at higher concentrations, 1 also influenced NKX2-5 (Figure 3B) and GATA4 (Figure 3C) transcriptional activity and showed toxicity in human induced pluripotent stem cells (iPSCs), mouse embryonic stem cells (mESCs), and mESC-derived progenitor cells. $^{33}$

SAR Analysis. Southern Part: Scaffold Hopping. To identify structural features affecting inhibition of GATA4 and NKX2-5 transcriptional synergy, we first present an exploration of the chemical space of the southern part of the original hit compound 1 . Table 1 presents the biological activity of 
Scheme 4. Synthesis of Compounds 39a-o and 40 with Substituted Aryl and Heteroaryl Moieties Attached to the Isoxazole Ring $^{a}$

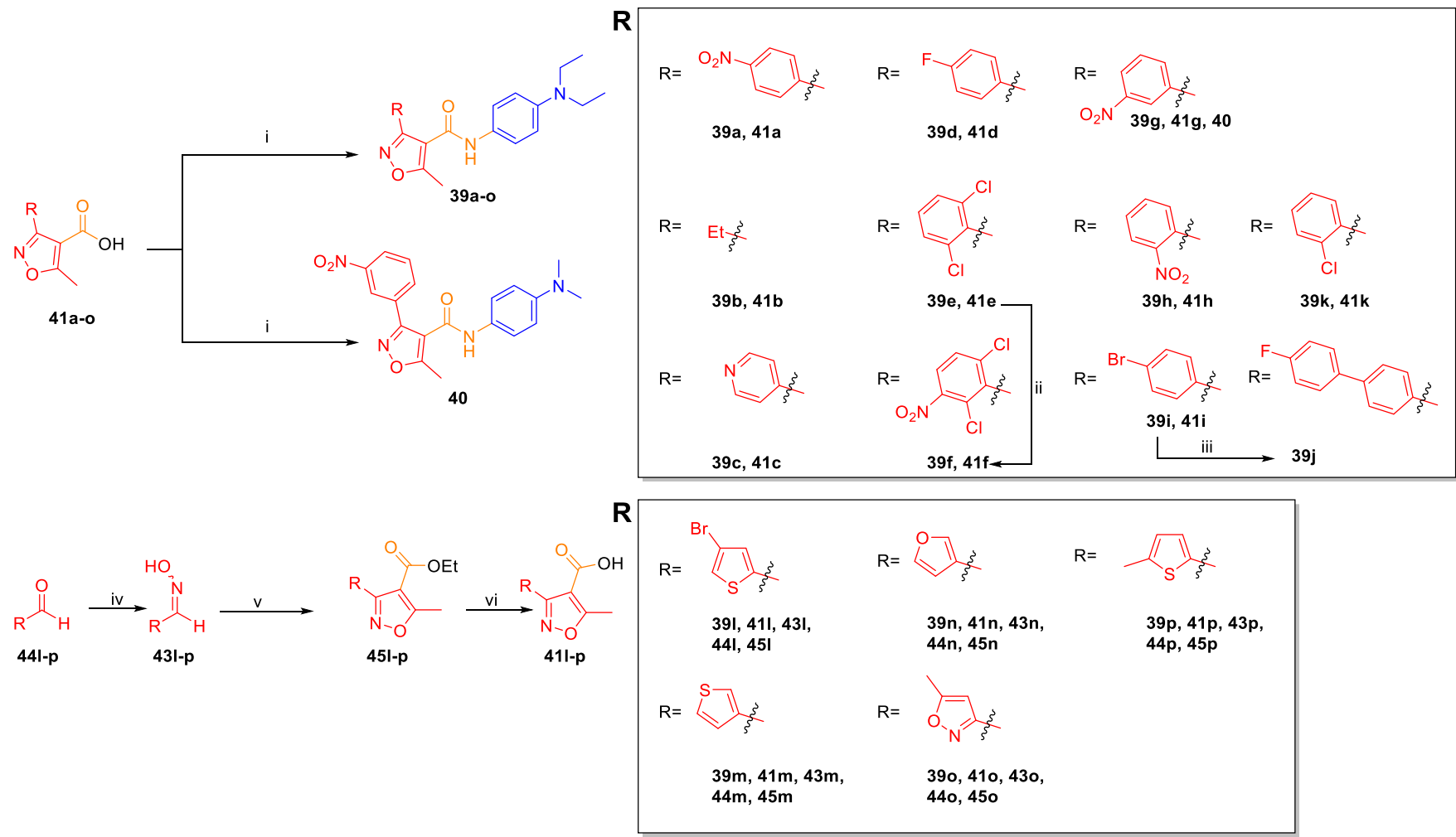

${ }^{a}$ Reagents and conditions: (i) N,N-diethyl-p-phenylenediamine (17) or $N, N$-dimethyl-p-phenylenediamine (42), HBTU or HATU, DIPEA, DMF, rt, 1-2 d; (ii) $\mathrm{HNO}_{3}$ (65\%), $\mathrm{H}_{2} \mathrm{SO}_{4}$ (conc.), $0{ }^{\circ} \mathrm{C}, 45 \mathrm{~min}, \mathrm{rt}, 2 \mathrm{~h}$; (iii) (4-fluorophenyl)boronic acid, $\mathrm{Pd}_{\left(\mathrm{Ph}_{3} \mathrm{P}\right)}, \mathrm{Na}_{2} \mathrm{CO}, \mathrm{PhMe} / \mathrm{EtOH}_{3} / \mathrm{H}_{2} \mathrm{O}$, EtOH, $80^{\circ} \mathrm{C}, 5 \mathrm{~h}, 70^{\circ} \mathrm{C}$, overnight; (iv) $\mathrm{H}_{2} \mathrm{NOH} \cdot \mathrm{HCl}$, py, EtOH ,rt, 1-4 h; (v) 45l-n, ethyl but-2-ynoate, DIB, TFA, $\mathrm{MeOH}$ or $\mathrm{MeOH} / \mathrm{H}_{2} \mathrm{O}, 0$ ${ }^{\circ} \mathrm{C} \rightarrow \mathrm{rt}, 2-3 \mathrm{~h}$; 45o, ethyl but-2-ynoate, PhI, Oxone, $\mathrm{H}_{2} \mathrm{O}$, rt, 18 h; 45p, ethyl but-2-ynoate, $\mathrm{KCl}, \mathrm{Oxone}, \mathrm{H}_{2} \mathrm{O}, \mathrm{rt}, 5 \mathrm{~h} ;(\mathrm{vi}) 45 \mathrm{l}, \mathrm{LiOH} \cdot \mathrm{H}_{2} \mathrm{O}, \mathrm{THF} /$ $\mathrm{MeOH} / \mathrm{H}_{2} \mathrm{O}$, rt, overnight; $41 \mathrm{~m}-\mathbf{o}, \mathrm{NaOH}, \mathrm{MeOH} / \mathrm{H}_{2} \mathrm{O}, 60{ }^{\circ} \mathrm{C}$ (or rt for 41o), 20-28 h.

selected derivatives comprising different heterocyclic scaffolds in the southern part, which in turn are differently substituted by aromatic and heteroaromatic residues as well as other structures. Herein, we focus on the heterocyclic core of the southern part, that is, isoxazole in $\mathbf{1}$. The compounds in Table 1 comprise other heterocycles in this region, or include an isoxazole with an aromatic residue in its 5 position. While the isoxazole in $\mathbf{1}$ is substituted by a phenyl group in the 3 position, many of the derivatives in Table 1 include heteroaryl residues instead of a phenyl substituent. The presumed effects of switching the phenyl unit to a heteroaryl moiety are discussed below together with other derivatives (Table 5).

The enhancers of the GATA4-NKX2-5 transcriptional synergy (Table 6) seem to contain a hydrogen-bond acceptor in the same position, indicating a role in the binding affinity of the compounds. In general, the hydrogen-bond acceptor capacity of the isoxazole structures is strongly localized on the nitrogen atom. In line with the reference compound $\mathbf{1}$, the methyl-substituted furan $\mathbf{5 4}$ and thiophene $\mathbf{5 6}$ also confirm this hypothesis. We found the hydrogen-bond acceptor with one or two atom distance to the position at which an aromatic moiety is attached to interfere with GATA4-NKX2-5 synergy in most structures.

A few derivatives are formally characterized by lacking the methyl group in the 5 position of the isoxazole ring in 1 . The activities of $47 \mathrm{~d}, 47 \mathrm{e}, 47 \mathrm{n}, 47 \mathrm{p}, 47 \mathrm{t}, 47 \mathrm{z}$, and 54 in luciferase assay indicate that this methyl group is not necessary for inhibiting GATA4-NKX2-5 transcriptional synergy. Partic- ularly noteworthy in this regard is the isothiazole $47 \mathrm{~s}$ and the thiophene $47 \mathbf{u}$ that are missing both substituents ( $\mathrm{Ph}, \mathrm{Me})$. These compounds had a clear inhibitory effect on transcriptional synergy. A change of the position of the aryl sustituent further away from the central part (compounds $47 \mathrm{~b}$ and $47 \mathrm{y}$ ) did not seem a promising approach. The aromatic substituent with a one-atom spacer (compound $47 \mathbf{q}$ ) could be further explored, but a two-atom spacer (compound 47i) did not seem to enhance the inhibitory effect on GATA4-NKX2-5 interaction. Also, replacing the isoxazole with a bicyclic unit, that is, $47 \mathbf{j}, 47 \mathbf{v}, 47 \mathbf{a a}$, and $47 \mathbf{a b}$, was not a promising approach, although the number of these derivatives is too small to allow drawing final conclusions. We also note that some derivatives with a bicyclic unit, such as $47 \mathbf{v}$ and $47 \mathrm{aa}$, indicate promising features for the development of enhancers of GATA4-NKX2-5 transcriptional synergy.

Central Part: Hydrogen-Bond Accepting Heteroatoms. In our previous study, ${ }^{29}$ we concluded that relatively rigid linkers, such as amides or imines, are beneficial moieties for inhibiting the transcriptional synergy between GATA4 and NKX2-5, and that a hydrogen-bond acceptor in the central part, such as the carbonyl oxygen, linked via a one-atom spacer to the southern part but not directly connected to the northern part may contribute to inhibition of the transcriptional synergy between GATA4 and NKX2-5. The luciferase assay results of the compounds with alternative central parts (Table 2) support our previous conclusions. Indeed, GATA4-NKX2-5 transcriptional synergy was diminished with the formal removal of the 
Table 1. Activities of Derivatives with Structurally Diverse Southern Parts (\% of Control) at $10 \mu \mathrm{M}_{\text {Concentration }}{ }^{a}$

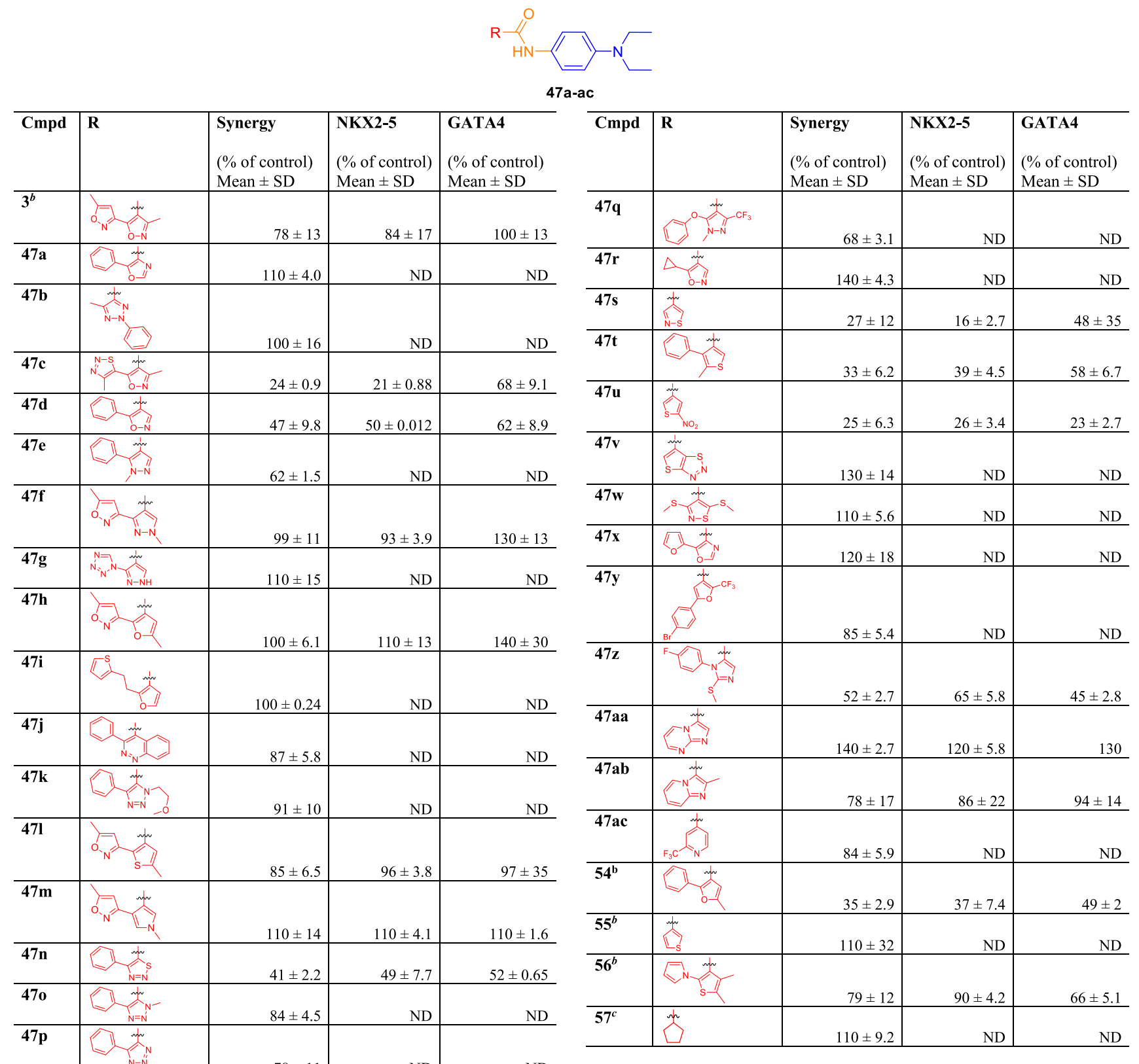

${ }^{a}$ Reagents and conditions: Compounds $47 \mathrm{a}-\mathrm{ac}$ were synthesized from the corresponding carboxylic acids $\mathrm{RCO}_{2} \mathrm{H} 46 \mathrm{a}-\mathrm{ac}(17$, HBTU/HATU, DIPEA, DMF, rt, 1-2 d). ${ }^{b}$ Synthesis previously described. ${ }^{33}{ }^{c}$ Commercial compound (see Table S1 for details). ND, not determined. Abbreviations: Cmpd, compound.

respective hydrogen-bond acceptor in $19,20,30 \mathrm{a}, 31$, and 33 , and in the case of the weaker hydrogen-bond acceptors, that is, thioamides 23 and 26, their S-alkylated derivatives 24a,b, and tertiary amine $30 \mathrm{~b}$. In addition, we found that a series of compounds that contained a carbonyl group with hydrogenbond accepting properties one atom further away from the southern part, that is, the $\mathrm{N}$-acylated amines $16,30 \mathrm{c}$, and 58 , showed remarkable inhibitory action on GATA4-NKX2-5 interaction. Therefore, it seems that a hydrogen-bond accepting heteroatom in the central part is indeed beneficial for inhibiting the transcriptional synergy between GATA4 and NKX2-5. However, regarding the distance and orientation to the southern part, an amide linker in the central part, as in $\mathbf{1}$, may not be an optimal moiety. Futher, we focused on the nitrogen atom of the amide linker in the central part. An acidic central part in compound $\mathbf{2 1}$ did not turn out to be a promising approach, and, for example, the derivative with a simple $N$-methyl substitution (25a) did not show inhibition of GATA4-NKX2-5 transcriptional synergy either. However, compounds $\mathbf{2 5 b , c}$, having larger fluoroethyl and benzyl substituents, respectively, still had moderate inhibitory action on GATA4-NKX2-5 interaction, indicating a potential space for substitution in this region of the central part.

Central Part: Ether Linkers. Besides the central linkers covered in Table 2, we investigated ether linkages (Table 3), characterized by a hydrogen-bond acceptor connected to the aromatic unit by a one-atom spacer. We found inhibitory activity in the GATA4-NKX2-5 transcriptional synergy assay 
Scheme 5. Autoxidation of Imines via a Secondary Amine Intermediate ${ }^{a}$

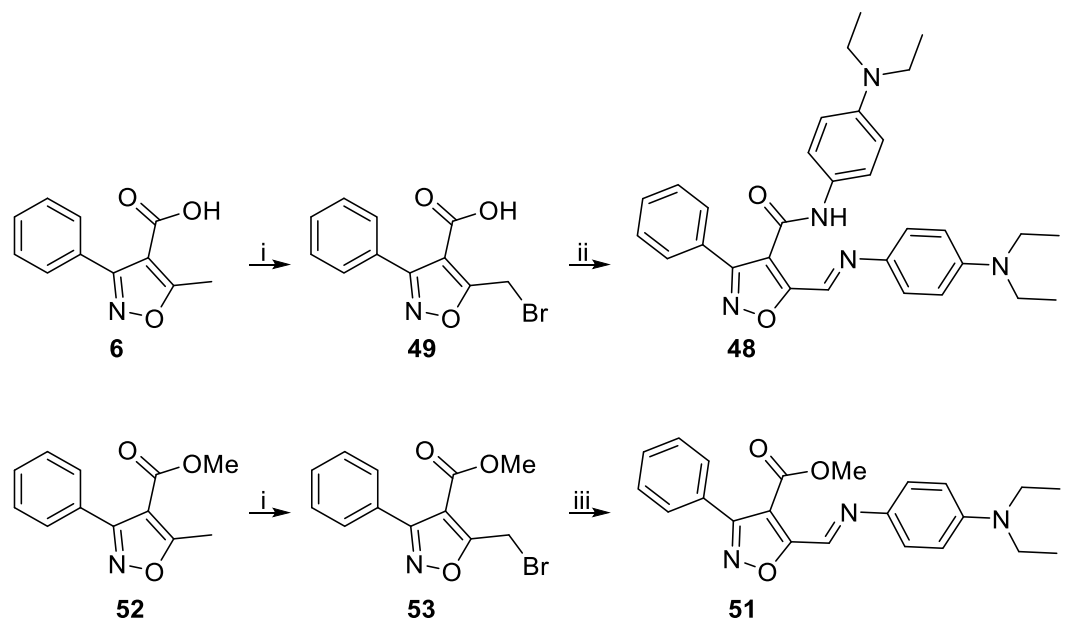

${ }^{a}$ Reagents and conditions: (i) (products not isolated and characterized) NBS, $\left(\mathrm{PhCO}_{2}\right)_{2}, \mathrm{CCl}_{4}$, reflux, $15 \mathrm{~h}$ (or for 53: reflux for $6 \mathrm{~h}$ and $\mathrm{rt}$ for $4 \mathrm{~d}$ ); (ii) N,N-diethyl-p-phenylenediamine hydrochloride (50), HBTU, DIPEA, DMF, rt, $2 \mathrm{~d}$; (iii) $N, N$-diethyl-p-phenylenediamine, MeOH, mw (120 ${ }^{\circ} \mathrm{C}, 30 \mathrm{~min}$ ).

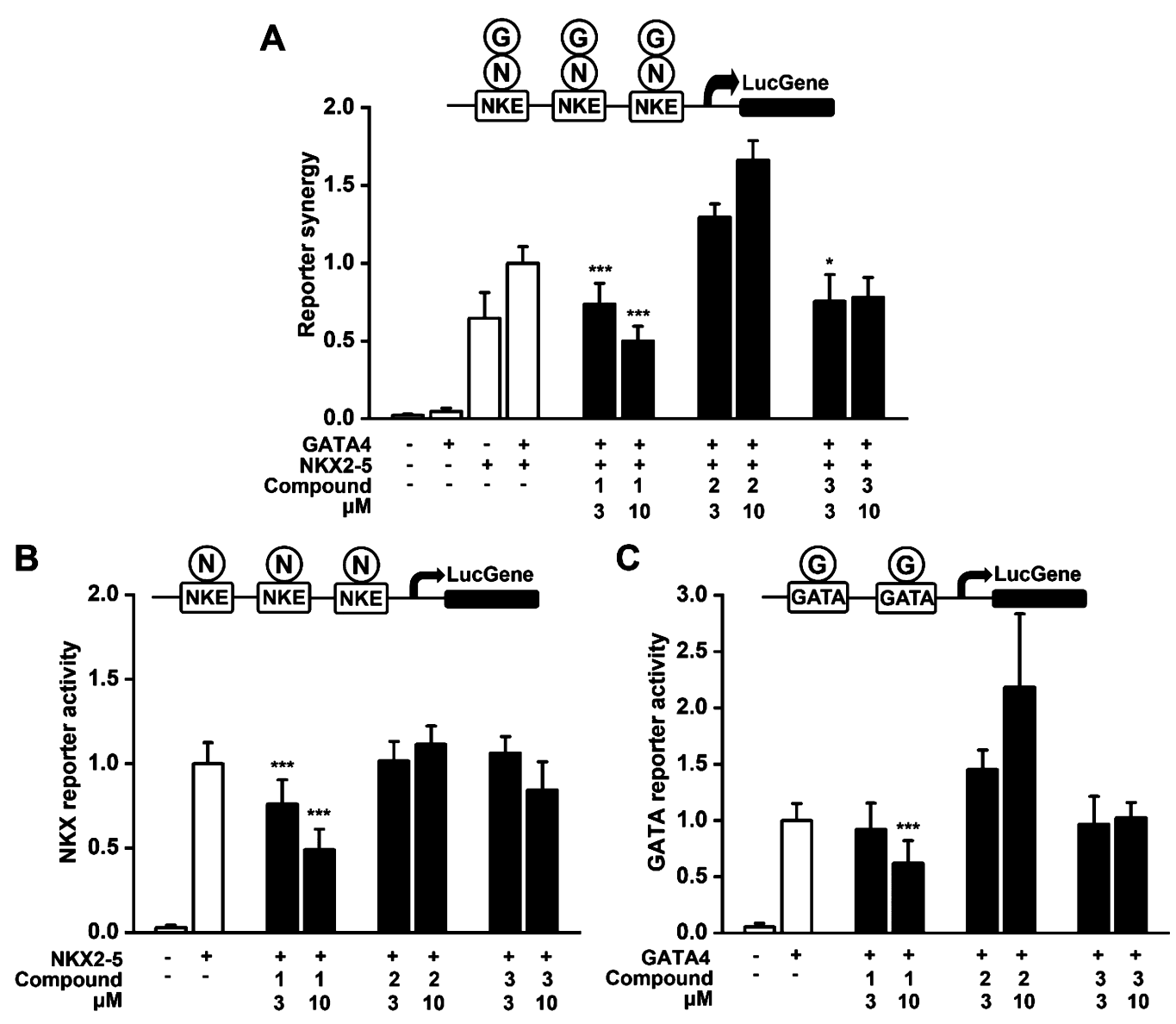

Figure 3. Luciferase screening assays. (A) The effects of compounds 1, 2, and 3 on GATA4 and NKX2-5 induced synergistic activation of the luciferase reporter gene containing three NKX-binding sites. The assay can detect both compounds that inhibit and compounds that increase synergistic activation. Results are the average $( \pm S D)$ of several independent experiments $(1, n=87 ; 3, n=4)$ except for compound 2 where one experiment with three technical replicates $( \pm S D)$ is presented. (B) The effects of compounds 1 , 2 , and 3 on NKX2-5-induced reporter gene activation. Results are average ( $\pm \mathrm{SD})$ of several independent experiments $(1, n=22 ; 2, n=2 ; 3, n=3)$. (C) The effects of 1, 2, and 3 on GATA4induced activation of a tandem GATA-site containing luciferase reporter construct. Results are the average $( \pm S D)$ of several independent experiments $(1, n=25 ; 2, n=3 ; 3, n=5)$. N denotes NKX2-5; G, GATA4; NKE, NKX-binding site; GATA, GATA-binding site. $* P<0.05$, $* * P<$ $0.01, * * * P<0.001$ (randomized block ANOVA followed by a Dunnett's post hoc test). 
Table 2. Central Part Modifications and Their Activities (\% of Control) at $10 \mu \mathrm{M}$ Concentration

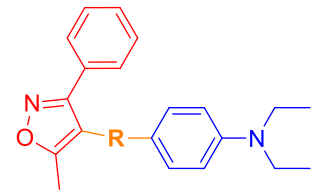

\begin{tabular}{|c|c|c|c|c|}
\hline Cmpd & $\mathbf{R}$ & $\begin{array}{l}\text { Synergy } \\
(\% \text { of control }) \\
\text { Mean } \pm \text { SD }\end{array}$ & $\begin{array}{l}\text { NKX2-5 } \\
(\% \text { of control }) \\
\text { Mean } \pm \text { SD }\end{array}$ & $\begin{array}{l}\text { GATA4 } \\
(\% \text { of control) } \\
\text { Mean } \pm \text { SD }\end{array}$ \\
\hline 16 & I & & & \\
\hline & $0=$ & $80 \pm 23$ & ND & ND \\
\hline 19 & & $100 \pm 2.6$ & ND & ND \\
\hline 20 & & $100 \pm 3.7$ & ND & ND \\
\hline 21 & 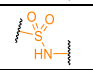 & $98 \pm 16$ & ND & ND \\
\hline 23 & $\mathrm{H}_{\mathrm{HN}-\mathrm{S}}^{\mathrm{S}}$ & $99 \pm 7.8$ & ND & ND \\
\hline $24 a$ & $\mathrm{~K}_{\mathrm{N}-\mathrm{S}}^{\mathrm{S}-}$ & $86 \pm 6.1$ & ND & ND \\
\hline $24 b$ & $H_{\mathrm{N}-1}^{\mathrm{S}-1}$ & $110 \pm 5.7$ & $\mathrm{ND}$ & ND \\
\hline $25 a$ & Ho & $97 \pm 9.9$ & $100 \pm 2.1$ & $99 \pm 13$ \\
\hline $25 b$ & & $79 \pm 0.092$ & ND & ND \\
\hline $25 c$ & & $66 \pm 13$ & ND & ND \\
\hline 26 & $H_{N}^{s}$ & $91 \pm 3.5$ & $\mathrm{ND}$ & ND \\
\hline 27 & $\begin{array}{c}7 \mathrm{NH} \\
\mathrm{O} \\
\end{array}$ & $94 \pm 14$ & $\mathrm{ND}$ & ND \\
\hline $30 a$ & $t_{N}$ & $82 \pm 8.0$ & $\mathrm{ND}$ & ND \\
\hline $30 \mathrm{~b}$ & & $53 \pm 4.1$ & $73 \pm 9.2$ & $80 \pm 0.12$ \\
\hline 30c & & $52 \pm 23$ & $71 \pm 7.3$ & $72 \pm 7.7$ \\
\hline 30d & & $85 \pm 2.6$ & ND & ND \\
\hline 31 & $F_{N}$ & $96 \pm 12$ & ND & ND \\
\hline 33 & $\mathrm{FNH}_{\mathrm{NH}}$ & $91 \pm 20$ & $89 \pm 2.5$ & $77 \pm 5.7$ \\
\hline $\mathbf{5 8}^{a}$ & & $22 \pm 4.9$ & $34 \pm 4.1$ & $43 \pm 1.0$ \\
\hline
\end{tabular}

${ }^{a}$ Synthesis previously described. ${ }^{33} \mathrm{ND}$, not determined. Abbreviations: Cmpd, compound.

for compounds, in which the northern and southern parts are connected by an ether bridge bearing the oxygen, a hydrogenbond acceptor, close to the northern part. While many of the compounds in this subset showed no significant activity, the retained inhibitory action on transcriptional synergy between GATA4 and NKX2-5 in case of $34 a$ and $34 e$ as well as $35 b$ and 35d demonstrated that ether bridges can be useful surrogates of the central part. We embarked upon exploring the chemical space in the region of the northern part's para position. The alcohol 34d did not show a significant effect, and the ketone $\mathbf{3 4 a}$ as well as the nitro derivative $34 \mathbf{b}$ only moderately inhibited the transcriptional synergy between GATA4 and NKX2-5. A better inhibition was observed with the benzyl ether 34e, vaguely indicating the tolerance of bulkier
Table 3. Northern Part Modifications of Ethers and Their Activities (\% of Control) at $10 \mu \mathrm{M}$ Concentration

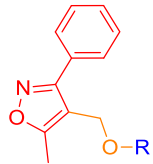

\begin{tabular}{|c|c|c|c|c|}
\hline Cmpd & $\mathbf{R}$ & $\begin{array}{l}\text { Synergy } \\
\text { (\% of control) } \\
\text { Mean } \pm \text { SD }\end{array}$ & $\begin{array}{l}\text { NKX2-5 } \\
\text { (\% of control) } \\
\text { Mean } \pm \text { SD }\end{array}$ & $\begin{array}{l}\text { GATA4 } \\
\text { (\% of control) } \\
\text { Mean } \pm \text { SD }\end{array}$ \\
\hline $34 a$ & & $76 \pm 18$ & $80 \pm 13$ & $78 \pm 19$ \\
\hline $34 b$ & & $85 \pm 3.9$ & $\mathrm{ND}^{a}$ & ND \\
\hline $34 c$ & & $110 \pm 9.7$ & ND & ND \\
\hline 34d & & $87 \pm 20$ & ND & ND \\
\hline $34 \mathrm{e}$ & & $43 \pm 3.5$ & $67 \pm 13$ & $78 \pm 7.4$ \\
\hline $35 a$ & & $26 \pm 0.42$ & $29 \pm 11$ & $41 \pm 1.7$ \\
\hline 35b & & $52 \pm 8.3$ & $52 \pm 22$ & $71 \pm 37$ \\
\hline $35 c$ & & $100 \pm 8.7$ & ND & ND \\
\hline 35d & & $37 \pm 3.0$ & $41 \pm 14$ & $44 \pm 7.5$ \\
\hline $35 e$ & & $99 \pm 22$ & ND & ND \\
\hline $36 a$ & & $100 \pm 9.7$ & ND & ND \\
\hline 36b & & $92 \pm 18$ & ND & ND \\
\hline 38 & & $120 \pm 5.3$ & ND & $\mathrm{ND}$ \\
\hline
\end{tabular}

${ }^{a} \mathrm{ND}$, not determined. Abbreviations: Cmpd, compound.

substituents. However, attempts to couple bigger residues via ester or amide linkages gave varied results. Many of the ester derivatives (34c, 35c, and 35e), the two amides 36a,b, and the benzoic acid 38 showed no significant inhibition of the transcriptional synergy between GATA4 and NKX2-5. Inhibition with bulky substituents was only obtained with the esters $35 \mathbf{a}, \mathbf{b}$ and $\mathbf{3 5 d}$, which are not only bigger, but contained also polar groups, such as carbonyl or nitrile, capable of acting as hydrogen-bond acceptors.

Northern Part. Next we explored the chemical space concerning the northern part and the substituent in the para position in particular (Table 4). This set of compounds consists of an amide linkage in the central part. The same linkage is found in the original hit compound $\mathbf{1}$, which was the second most potent inhibitor of the transcriptional synergy between GATA4 and NKX2-5, only exceeded by its homologue $4 \mathbf{i}$. The meta-aryl-substituted derivatives of $\mathbf{1}$ and $\mathbf{4 i}$, that is, compounds $\mathbf{4 c ,} \mathbf{8}$, and $\mathbf{9}$, were less active, indicating limited space in the binding conformation concerning the meta position. However, the slight synergy inhibitory potency of all three compounds, $4 c, 8$, and 9 , indicates that nucleophilicity or basicity of the aniline nitrogen atom is of minor importance for the required GATA4 and NKX2-5 protein interaction. In addition, the moderate inhibitor $\mathbf{4 a}$ and the chromen-4-one derivative $\mathbf{4 g}$ with potent inhibitory effect on the transcriptional synergy between GATA4 and NKX2-5 can formally be regarded as meta-substituted derivatives. The greater inhibitory activity of the latter derivative $\mathbf{4 g}$ as compared to $\mathbf{4 a}$ as well as the missing inhibitory activity of $\mathbf{4 d}$ as compared to $\mathbf{1}$ indicate once more a benefit of bulky substituents beyond the northern 
Table 4. Selected Northern Part Modifications and Their Activities (\% of Control) at $10 \mu \mathrm{M}$ Concentration

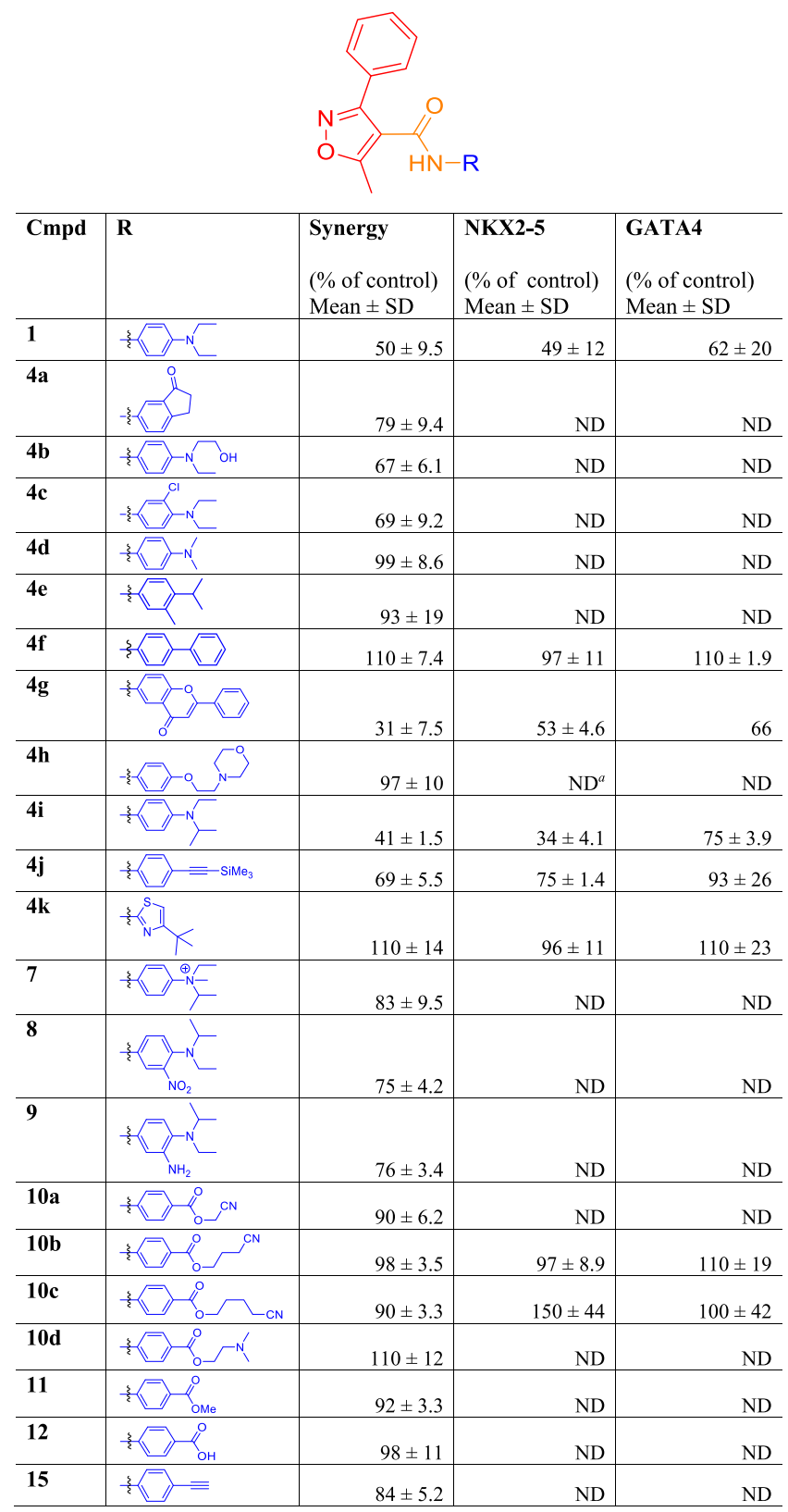

${ }^{a} \mathrm{ND}$, not determined. Abbreviations: Cmpd, compound.

part's para position. In this respect, it is interesting to note the missing transcriptional synergy inhibitory activity of the nitrile derivatives 10a, 10b, and 10c. The analogous ethers 35a and $35 \mathbf{b}$ were potent and moderate inhibitors, respectively (Table $3)$. However, the striking difference in the effects on GATA4NKX2-5 interaction of these ether linked compounds and the corresponding amide linked analogues may not originate from different interactions between the small molecules and the proteins. Although not investigated in detail, we note that molecular stability may be the cause of different effects on GATA4-NKX2-5 transcriptional synergy. While the ether bridged derivatives $\mathbf{3 5 a} \mathbf{a} \mathbf{b}$ can be considered as phenylogous carbonates, the amide linked $\mathbf{1 0 a}-\mathbf{c}$ are formally phenylogous $\mathrm{N}$-aroyl carbamates. Therefore, the latter compounds may be more prone to hydrolysis in biological media. On the assumption of stability, however, electronic effects on the isoxazole ring may explain the difference in synergy inhibitory activity. The $\mathrm{sp}^{2}$ carbon in $\mathbf{3 5 a} \mathbf{a} \mathbf{b}$ is not electron withdrawing. Likewise, the carbonyl carbon of the linking amide in compounds such as $\mathbf{1}$ or $\mathbf{4 i}$ is stabilized by the electron delocalization in the conjugated and aromatic phenylenediamine structure, so that the electron-withdrawing properties are low. Such a stabilization does not apply to the corresponding carbonyl carbons of $10 a-c$, because they are part of phenylogous $\mathrm{N}$-carbonyl carbamates. Therefore, the carbonyl group in the central parts of $10 a-c$ should have a considerable electron-withdrawing effect on the isoxazole ring.

Because of these possible explanations for the lack of synergy inhibitory activity of $\mathbf{1 0 a}-\mathbf{c}$, the hypothesis that a bulky substituent bearing a polar group in this molecular region beyond the para position in the northern part is beneficial for inhibition of GATA4-NKX2-5 interaction (Table 3) remains still noteworthy and is further supported by the inhibitory activity of the alcohol $\mathbf{4 b}$. We also note that the alkynes $\mathbf{1 5}$ and 4j, which can be considered nonclassical hydrogen-bond acceptors, have slight synergy inhibiting activity. We also found that even the cationic derivative 7 slightly retained the GATA4-NKX2-5 transcriptional synergy inhibition.

Southern Part: Isoxazole Substituent. We explored the chemical space in the region of the southern part further. In our previous study, ${ }^{33}$ we reported the importance of an aromatic substituent at the isoxazole scaffold of the southern part (typically in 3-position) for the GATA4-NKX2-5 transcriptional synergy activation/inhibition and concluded that the dihedral angle between the isoxazole and the aromatic substituent could serve as a predictor for stem cell toxicity. ${ }^{33}$ In this study, compounds with differently substituted phenyl residues and derivatives with heteroaryl residues in the southern part were synthesized to further explore the influence of conformational as well as steric and electronic effects concerning isoxazole aryl substituents on the GATA4-NKX25 -induced synergistic activation of the promoter containing three NKX2-5 binding sites. In the case of ortho-substituted aryl residues, electronic effects and steric effects that likely result in different conformational preferences with respect to greater dihedral angles between the two aromatic moieties cannot be clearly distinguished from each other. However, the luciferase assay results of this subset of compounds indicate that ortho substitution is not beneficial for the inhibition of GATA4-NKX2-5 transcriptional synergy. The dichloro derivatives $39 \mathrm{e}-\mathrm{f}$ as well as the chloro derivative $39 \mathrm{k}$ and the nitro derivative $39 \mathrm{~h}$ were less active than the reference compound 1. Heterocycles that contained a heteroatom in the corresponding position (the 2 position) were at most slightly active (391) or not active at all $(390,39 p, 59$, and 60). In the case of ortho substituents, steric repulsions are likely to result in unfavorable, large dihedral angles between the isoxazole and phenyl ring. In the case of heteroatoms in the 2 position, we assume unfavorable electrostatic interactions with the amide linker of the central part, leading to the less optimal dihedral angles between isoxazole and heterocycle, less optimal orientations of the amide linker, or both. Although limited in number, the results of these derivatives indicate that modification in ortho positions (the 2 position) is unlikely to improve the inhibitory potency of GATA4-NKX2-5 transcriptional synergy.

Also, meta-substituted aryl residues were less active as synergy inhibitors as compared to 1 , although $39 \mathrm{f}, 39 \mathrm{~g}$, and 
391 retained some of the GATA4-NKX2-5 transcriptional synergy inhibition. The improved activity of $39 \mathrm{~g}$ as compared to the inactive $\mathbf{4 0}$ complies with the enhanced activity of $\mathbf{1}$ as compared to the inactive $\mathbf{4 d}$ (Table 4). Concerning

Table 5. Selected Compounds with Varied Isoxazole Substituents and Their Activities (\% of Control) at $10 \mu \mathrm{M}$ Concentration

\begin{tabular}{|c|c|c|c|c|}
\hline Cmpd & $\mathbf{R}$ & $\begin{array}{l}\text { Synergy } \\
(\% \text { of control) } \\
\text { Mean } \pm \text { SD }\end{array}$ & $\begin{array}{l}\text { NKX2-5 } \\
\text { (\% of control) } \\
\text { Mean } \pm \text { SD }\end{array}$ & $\begin{array}{l}\text { GATA4 } \\
\text { (\% of control) } \\
\text { Mean } \pm \text { SD }\end{array}$ \\
\hline 39a & $\mathrm{O}_{2} \mathrm{~N}$ & $100 \pm 16$ & $\mathrm{ND}^{c}$ & $\mathrm{ND}$ \\
\hline $39 \mathrm{~b}$ & Ety? & $100 \pm 0.85$ & $160 \pm 97$ & $140 \pm 38$ \\
\hline $39 c$ & 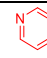 & $61 \pm 7.5$ & $61 \pm 0.94$ & $79 \pm 8.4$ \\
\hline 39d & & $44 \pm 1.1$ & $47 \pm 0.79$ & $79 \pm 0.015$ \\
\hline $39 \mathrm{e}$ & & $110 \pm 5.0$ & ND & ND \\
\hline 39f & & $66 \pm 2.6$ & ND & ND \\
\hline $39 \mathrm{~g}$ & & $65 \pm 3.7$ & ND & ND \\
\hline $39 \mathrm{~h}$ & NO & $84 \pm 1.3$ & ND & ND \\
\hline $39 \mathrm{i}$ & & $70 \pm 6.4$ & ND & ND \\
\hline $39 j$ & & $110 \pm 12$ & ND & ND \\
\hline 39k & & $88 \pm 14$ & $97 \pm 34$ & $110 \pm 36$ \\
\hline 39l & & $89 \pm 25$ & ND & $\mathrm{ND}$ \\
\hline $39 m$ & $\Delta$ & $66 \pm 4.2$ & $84 \pm 9.4$ & $71 \pm 13$ \\
\hline 39n & 0 & $110 \pm 5.8$ & $110 \pm 28$ & $99 \pm 4.5$ \\
\hline 390 & & $100 \pm 13$ & $87 \pm 2.6$ & $100 \pm 9.4$ \\
\hline 39p & & $100 \pm 2.0$ & $88 \pm 2.0$ & $92 \pm 2.1$ \\
\hline 40 & & $100 \pm 1.8$ & ND & ND \\
\hline $\mathbf{5 9}^{a}$ & & $100 \pm 0.41$ & ND & ND \\
\hline $\mathbf{6 0}^{b}$ & & $100 \pm 6.1$ & $86 \pm 8.8$ & $110 \pm 9.2$ \\
\hline
\end{tabular}

${ }^{a}$ Commercial compound (see Table S1 for details). ${ }^{b}$ Synthesis previously described. ${ }^{33} \mathrm{ND}$, not determined. Abbreviations: Cmpd, compound.

heteroatoms in the corresponding position (position 3 of the aromatic substituent), the furan derivative 39 n did not show inhibition of GATA4-NKX2-5 interaction, but the thiophene derivative $39 \mathrm{~m}$ was a moderate synergy inhibitor. As compound 39f was an active synergy inhibitor and 39e had no effect on GATA4-NKX2-5 transcriptional synergy, the limited data suggest that modifications of the meta position, that is, heteroatoms in the 3 position of a heterocycle, are tolerated, although they do not seem to be particularly promising for enhancing the synergy inhibitory activity.

The most promising results were obtained by alterations of the para position, that is, replacing the carbon ring atom in the corresponding position with a nitrogen atom. Although the para-substituted derivatives $39 \mathbf{a}$ and $39 \mathbf{j}$ were inactive as inhibitors of GATA4-NKX2-5 transcriptional synergy, the para-fluoro derivative $39 \mathrm{~d}$ was as potent as 1 , and also the bromo derivative $39 \mathbf{i}$ and the pyridine 39c were moderately active synergy inhibitors. The difference between the fluoro derivative $39 \mathrm{~d}$ and the corresponding bromo derivative $39 \mathrm{i}$ is commented as follows. First, as bromine has a considerably greater atomic size than fluorine, it could be hypothesized that in the conformation of protein interaction the space around the para position is limited. This assumption is supported by the inactivity of $39 \mathrm{a}$ and $39 \mathbf{j}$ as synergy inhibitors. Second, electronic effects may be relevant. The greater atomic size of bromine as compared to fluorine leads also to different electronic properties. Aromatic halogen substituents have inductively withdrawing $(-\mathrm{I})$ and resonance donating $(+\mathrm{M})$ effects. While the fluoro substituent has a stronger $-\mathrm{I}$ effect than bromine due to its higher electronegativity, it also has a stronger $+\mathrm{M}$ effect. The larger $\mathrm{sp}^{3}$ orbitals of the bromo substituent only have a poor orbital overlap with the $\mathrm{sp}^{2}$ orbitals of the much smaller carbon atoms of the phenyl ring. Therefore, the electronic effect of the 4-bromophenyl residue in $39 \mathbf{i}$ on the isoxazole ring is slightly electron withdrawing, while the effect of the fluorophenyl residue in $39 \mathrm{~d}$ may be neutral or weakly electron donating. However, as the resonance system in $\mathbf{3 9 j}$ also consists of a fluorine substituent, the first hypothesis, stating that bulky substitution in para position is unfavorable, still appears as a likely one.

Although limited in number and structural variety, we suggest a following conclusion based on this subset on GATA4-NKX2-5 transcriptional synergy. The space around the aryl residue attached to the isoxazole ring appears to be limited particularly in ortho and para positions. While some compounds with electron-withdrawing aromatic moieties retained slight to moderate inhibition, their synergy inhibitory activity was reduced as compared to $\mathbf{1}$, indicating that residues at the 3 position of the isoxazole ring with electronwithdrawing effects are unfavorable. The potent synergy inhibitory activity of $\mathbf{3 9 d}$ and the moderate inhibitory activity of $39 \mathrm{~m}$ leave room for the hypothesis that, in fact, small electron-donating aromatic residues may have beneficial effects for inhibiting GATA4-NKX2-5 transcriptional synergy.

Noteworthy is also the missing inhibition of GATA4NKX2-5 transcriptional synergy of compound $39 \mathrm{~b}$ that contains an alkyl residue instead of an aromatic moiety. Lack of its synergy inhibitory activity is in agreement with our previous conclusions, ${ }^{38}$ highlighting the importance of an aromatic substituent at the isoxazole 3 position. However, as the following comparisons demonstrate, analogues containing heterocycles other than isoxazole can have high inhibitory action on the GATA4-NKX2-5 transcriptional synergy also without aromatic substitution (e.g., 61).

Molecular Structures Modulating GATA4 and NKX2-5 Transcriptional Synergy. In Table 6 we present collections of the most active inhibitors and enhancers of GATA4-NKX2-5 transcriptional synergy, and in Tables 7 and 8 GATA4 and NKX2-5 transcriptional activity, respectively. The comparison aims at the identification of compounds that specifically target 
Table 6. Structure and Activity (\% of Control) of the 10 Most Potent Inhibitors and Enhancers in the GATA4-NKX2-5 Synergy Assay at $10 \mu \mathrm{M}$ Concentration

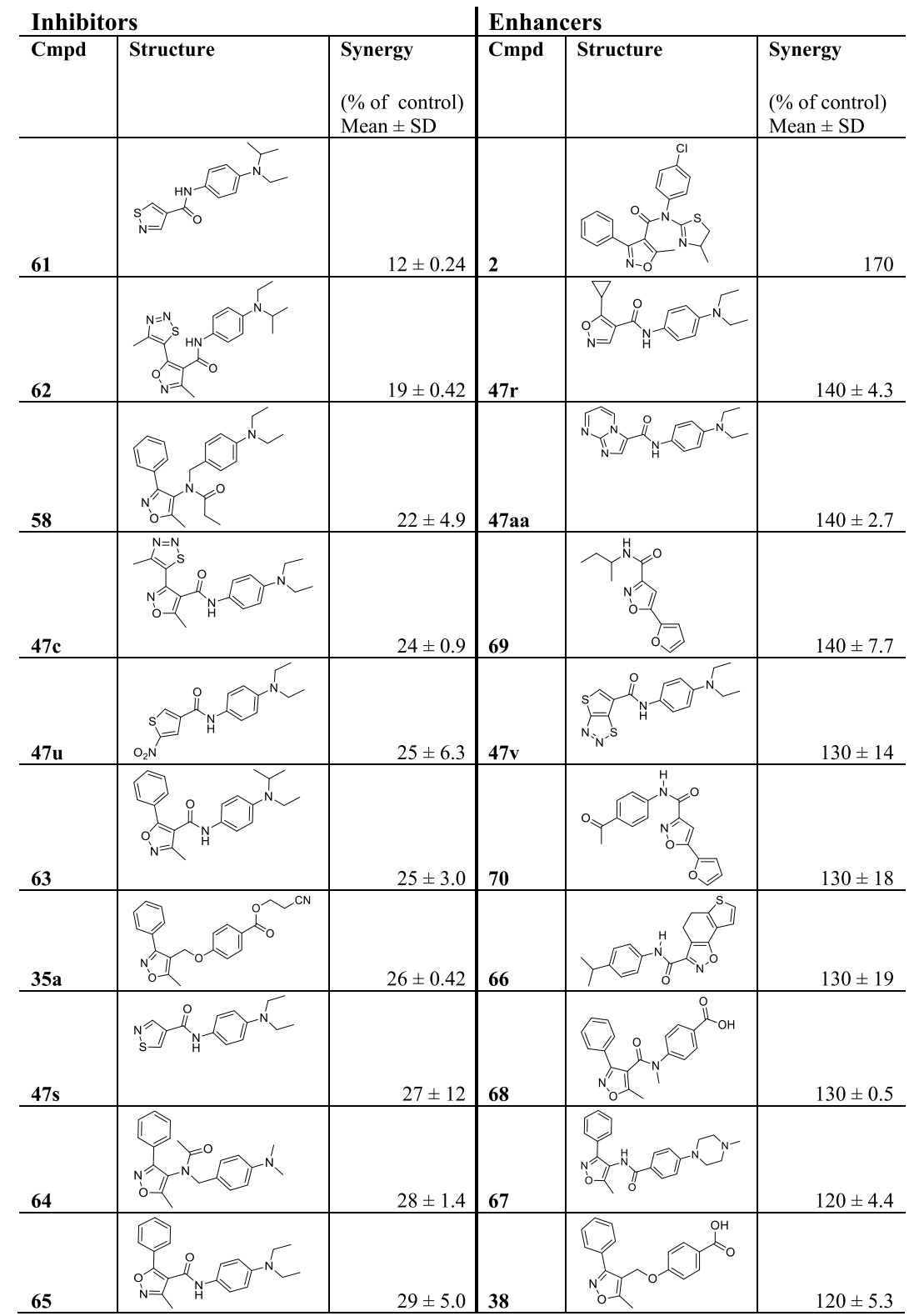

the synergy of GATA4 and NKX2-5 but not primarily influence on GATA4 and NKX2-5 gene transcription. In general, we found more potent inhibitors than convincing enhancers. Interestingly, in the GATA4-NKX2-5 luciferase reporter assay, the most potent inhibitor was isothiazole 61 . It contains the alkyl branching in the northern part from the inhibitory compound $\mathbf{4} \mathbf{i}$ and a small southern part with the unsubstituted isothiazole heterocycle. The synergy inhibitory compounds 62 and 63 had a similar alkyl branching in their northern parts, indicating that the additional alkyl branching is a valuable alternative to the diethylamino structure in $\mathbf{1}$. However, the latter residue is also present in 5 of the 10 most potent inhibitors (47c, $47 \mathrm{~s}$ and $47 \mathrm{u}, 58$, and 65 ) and thus remains a suitable and promising substituent in the northern part. While compound $\mathbf{6 1}$ is the most potent inhibitor in the GATA4-NKX2-5 transcriptional synergy assay, it is likewise the most potent inhibitor in both GATA4 and NKX2-5 transcriptional assays. As the second and fourth most potent inhibitors in the GATA4-NKX2-5 synergy assay (Table 6), compounds 62 and $47 \mathrm{c}$ are also structurally unique with 4methyl-1,2,3-thiadiazole substituents in the southern part. However, compound $47 \mathrm{c}$ showed high toxicity in MTT assay on cell viability (see below). Further, compounds 58 and 64, with an $\mathrm{N}$-acylated secondary amine central part, are potent inhibitors of GATA4-NKX2-5 transcriptional synergy. The dimethylamino residue in the northern part in $\mathbf{4 d}$ and $\mathbf{4 0}$ turned out to be inferior as compared to the diethylamino residue in 1 and $39 \mathrm{~g}$, respectively. Yet compound 64 showed moderate activity in inhibiting GATA4-NKX2-5 synergy despite the less favorable dimethylamino residue, suggesting the $\mathrm{N}$-acylated amine in the central part to be a promising alternative to the amide linker in $\mathbf{1}$.

Also, the ether-linked compound 35a, bearing the polar nitrile group in the northern part side-chain, was a potent inhibitor of GATA4-NKX2-5 synergy (Table 6), but showed comparable inhibition in the GATA4 and NKX2-5 transcrip- 
Table 7. Structure and Activity (\% of Control) of the 10 Most Potent Inhibitors and Enhancers in the GATA4 Luciferase Screening Assay at $10 \mu \mathrm{M}$ Concentration

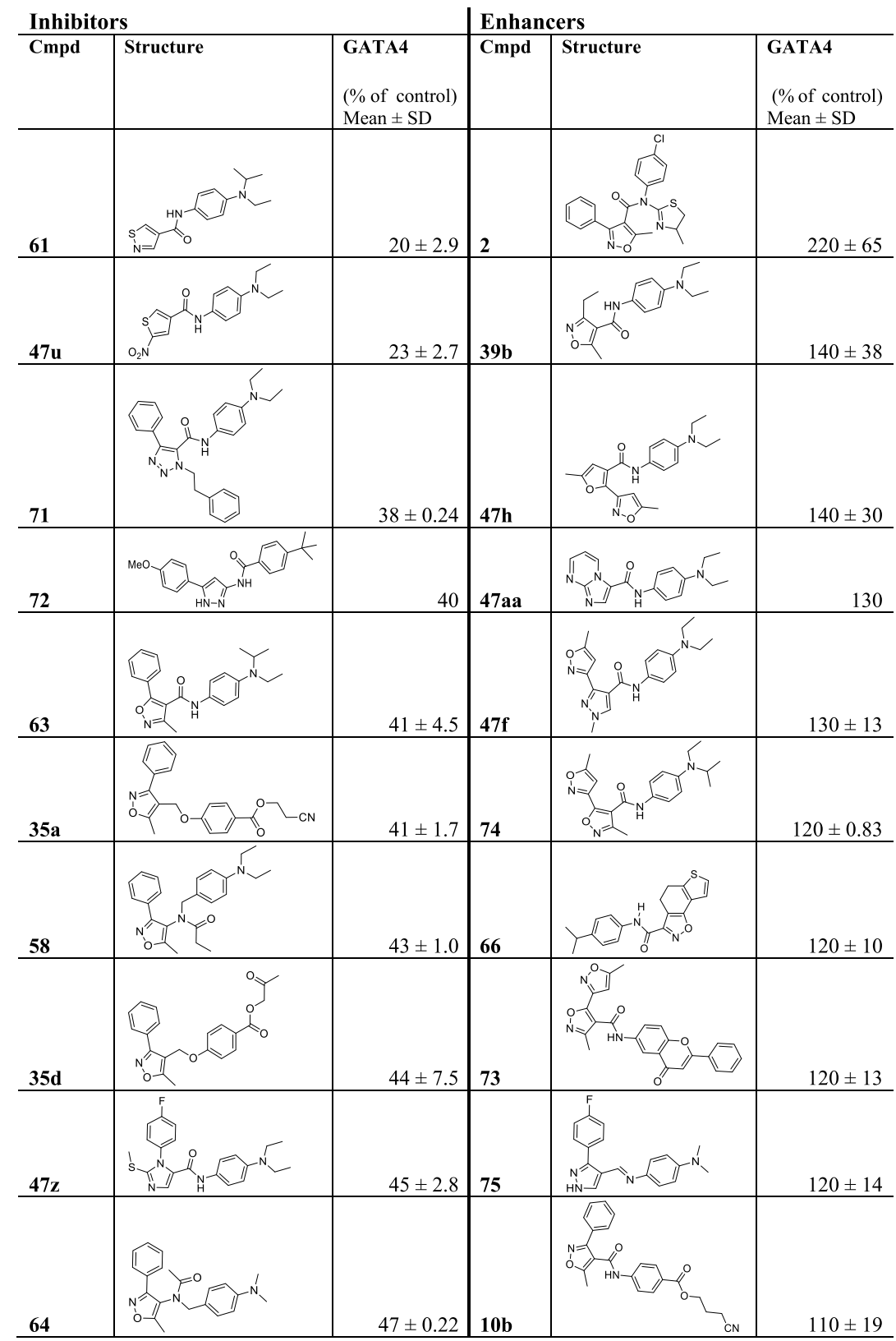

tional assays (Tables 7 and 8). Similar conclusions apply to compounds $47 \mathbf{u}$ and 63 . They showed no selectivity for GATA4-NKX2-5 synergy.

Finally, compound $\mathbf{6 5}$, the analogue of 1 with a reversed substituent pattern at the isoxazole ring, was among the 10 most potent inhibitors of GATA4-NKX2-5 transcriptional synergy. Our original hit compound $\mathbf{1}$ is not placed among the 10 most potent inhibitors in Tables $6-8$, demonstrating that the aim of this study, optimization of the hit compound $\mathbf{1}$, was possible and successful. Various compounds with better inhibiting potency were found, and some of them appear to target specifically the protein-protein interaction of GATA4 and NKX2-5.

The most potent enhancer of the GATA4-NKX2-5 transcriptional synergy, compound 2, was identified in our previous study. ${ }^{29}$ As compound 2 was also found to be a strong enhancer in the GATA4 transcriptional assay, but not in the NKX2-5 transcription assay, we note that the enhancing properties of 2 largely result from an interaction with GATA4. As the enhancing properties of most compounds are only moderate, systematic conclusions are difficult to draw.

Of note, throughout Tables 6-8, compounds devoid or partially missing the entire northern part (47f, 66, 69, and 70) are typically found among the enhancers of transcriptional activity. Concerning inhibitors, compound $\mathbf{7 2}$ showing inhibition potency both in transcriptional synergy and in the GATA4 transcriptional assay (Table 7) may be regarded as a compound lacking the northern part. Further compounds with bicyclic arrangements in the southern part, such as $47 \mathbf{a a}$ and $47 \mathrm{v}$, were found to have transcription enhancing properties.

Also, compounds with methyl substituents at the positions corresponding to the isoxazole nitrogen or oxygen atom in the 
Table 8. Structure and Activity (\% of Control) of the 10 Most Potent Inhibitors and Enhancers in the NKX2-5 Luciferase Screening Assay at $10 \mu \mathrm{M}$ Concentration

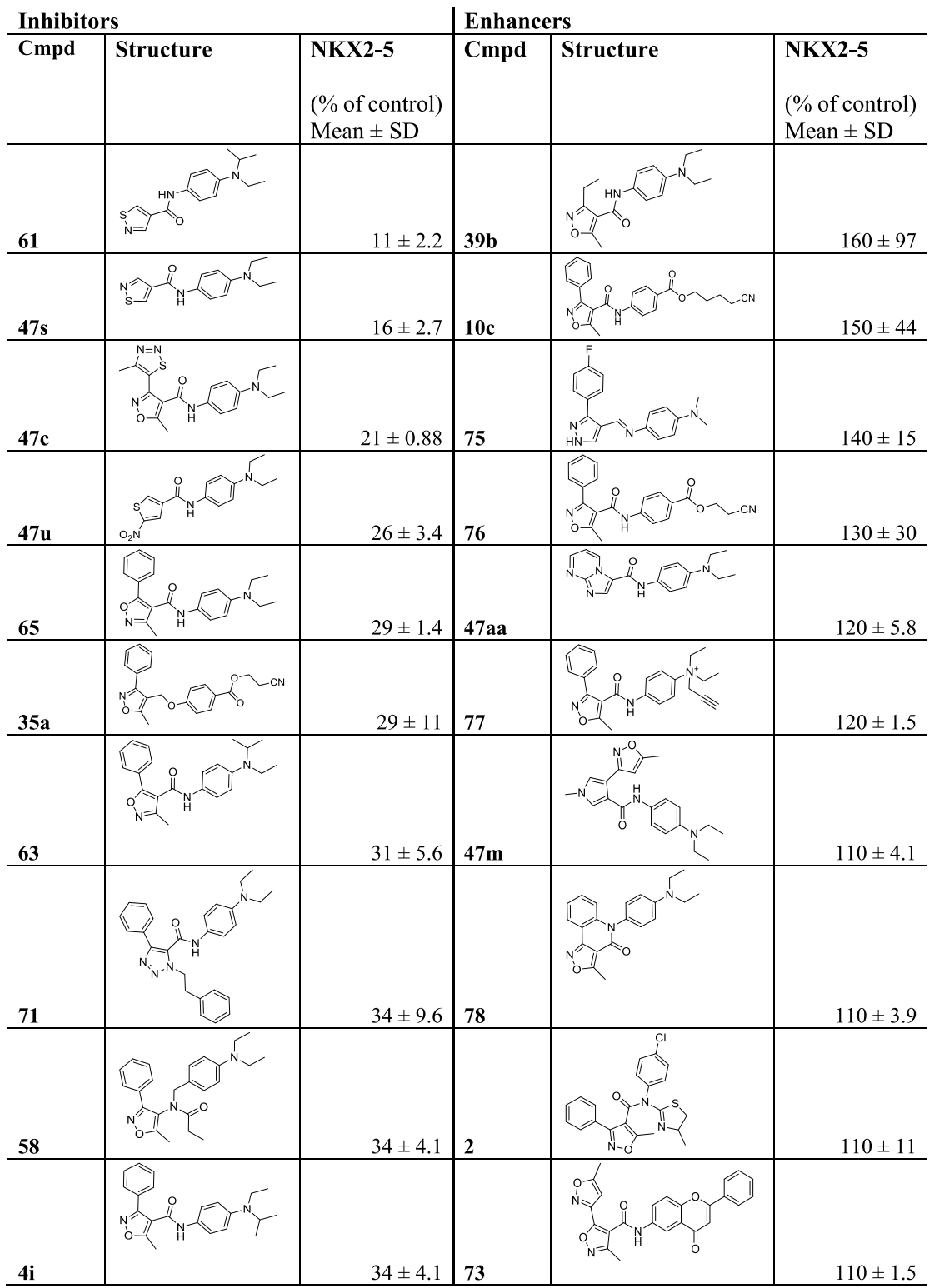

${ }^{a} \mathrm{ND}$, not determined.

southern part of 1 , such as $47 \mathrm{f}, 47 \mathrm{~h}$, and $47 \mathrm{~m}$, show transcription enhancing properties. In addition, compounds with alkyl but no aromatic substitution at the 3 and/or 5 position of the isoxazole ring, such as $39 \mathrm{~b}$ and $47 \mathrm{r}$, had transcription enhancing properties. In particular, the derivative $39 \mathrm{~b}$ is a very interesting compound. It is ranked the most potent enhancer in the NKX2-5 transcriptional assay (Table 8) and the second most active in the GATA4 assay (Table 7), but is not included in Table 6 and has therefore a negligible effect on GATA4-NKX2-5 synergy. The pyrazole 75 has a similar activity pattern, although its enhancing potency is weaker. Interestingly, compound $\mathbf{7 8}$, a cyclic derivative of $\mathbf{1}$, in which the orientation of the amide bond of the central part is fixed, had no effect on the GATA4-NKX2-5 transcriptional synergy and was rather a weak enhancer in the NKX2-5 transcriptional assay (Table 8). The finding may contribute to the understanding of the binding conformation of $\mathbf{1}$. Despite the weak inhibiting potency of 7 (Table 4) and missing or at most very weak enhancing properties of $\mathbf{1 0 d}$ and $\mathbf{4 h}$ (Table 4), respectively, the weak enhancing capabilities of the piperidine 67, likely protonated in biological media, and of the cation 77 tentatively hint that a positive charge in the northern part may contribute to transcriptional enhancing properties. Compounds such as $47 \mathbf{r}, 47 \mathbf{v}, 67,68,69$, and 70 seem to affect only the GATA4-NKX2-5 transcriptional synergy, but the enhanced potency as percent of control is rather weak, making it difficult to draw convincing conclusions of this subset of compounds.

GATA4 and NKX2-5 Transcriptional Assay. Next, we focus on the GATA4 luciferase reporter gene assay (Table 7) and the NKX2-5 transcriptional activity (Table 8). In particular, the 2-nitrothiophene derivative $47 \mathbf{u}$ was active in all of the assays, which indicates that its activity is not selective for the GATA4-NKX2-5 transcriptional synergy. Also, the potent 


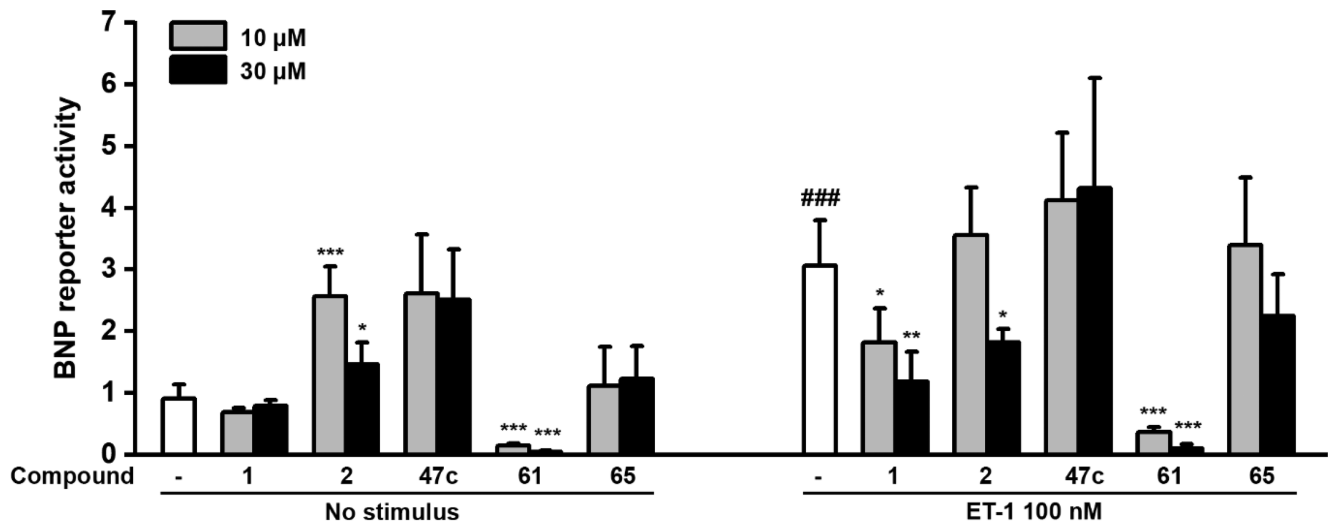

Figure 4. Effects of the compounds $1,2,47 \mathrm{c}, 61$, and 65 on BNP gene activation in cardiomyocytes. Neonatal cardiomyocytes were transfected with rat BNP luciferase reporter for $24 \mathrm{~h}$. The cells were exposed to compounds and $1 \mathrm{~h}$ later to endothelin-1 (ET-1) for $24 \mathrm{~h}$. The results are expressed as $+\mathrm{SD}(n=3$ or 9 for DMSO groups). $* * * P<0.001$ vs DMSO; $* * P<0.01$ vs DMSO; $* P<0.05$ vs DMSO (one-way ANOVA followed by Tukey's HSD or Welch ANOVA followed by Games-Howell); ${ }^{\# \#} P<0.001$ vs DMSO, no stimulus (independent samples Student's $t$ test).
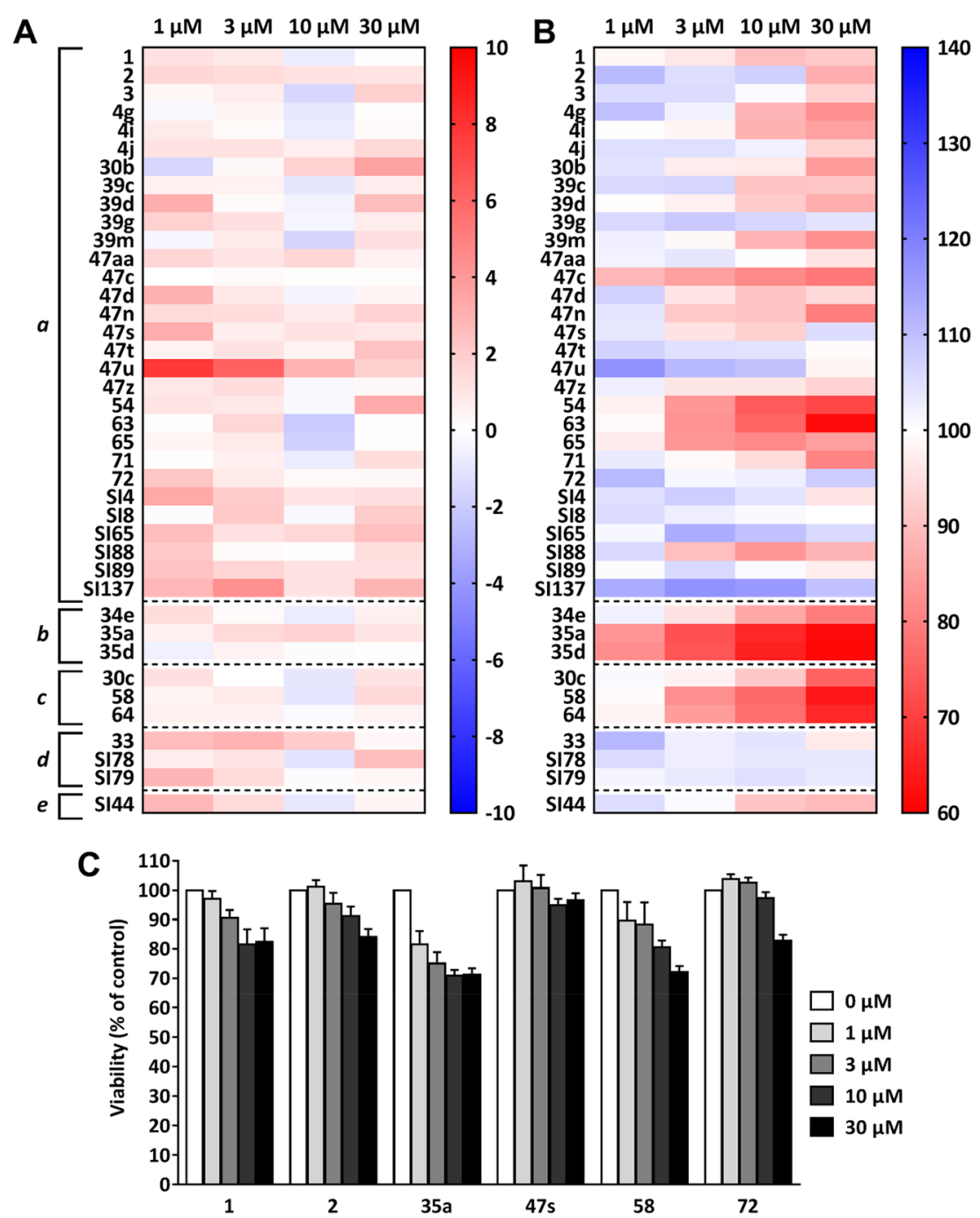

Figure 5. Effects of selected compounds on COS-1 cell viability. (A) Compound-induced necrosis was quantified with the LDH assay after a $24-\mathrm{h}$ compound exposure. The data are presented as cytotoxicity percentage (\% of maximal LDH release). (B) Cell viability was analyzed with the MTT assay after a 24-h compound exposure. (A,B) The data are means from 2-3 independent experiments with 3 replicate wells in each and are presented as $\%$ of control (vehicle-treated cells). The compounds have been grouped on the basis of the structure of the central part: $a$, amide; $b$, ether; $c, \mathrm{~N}$-acylated amine; $d$, amine; and $e$, imine. (C) The effects of selected compounds on cell viability as determined by ATP content after a 24$\mathrm{h}$ compound exposure. The data are mean + SEM from three independent experiments and are presented as \% of vehicle-treated cells. 


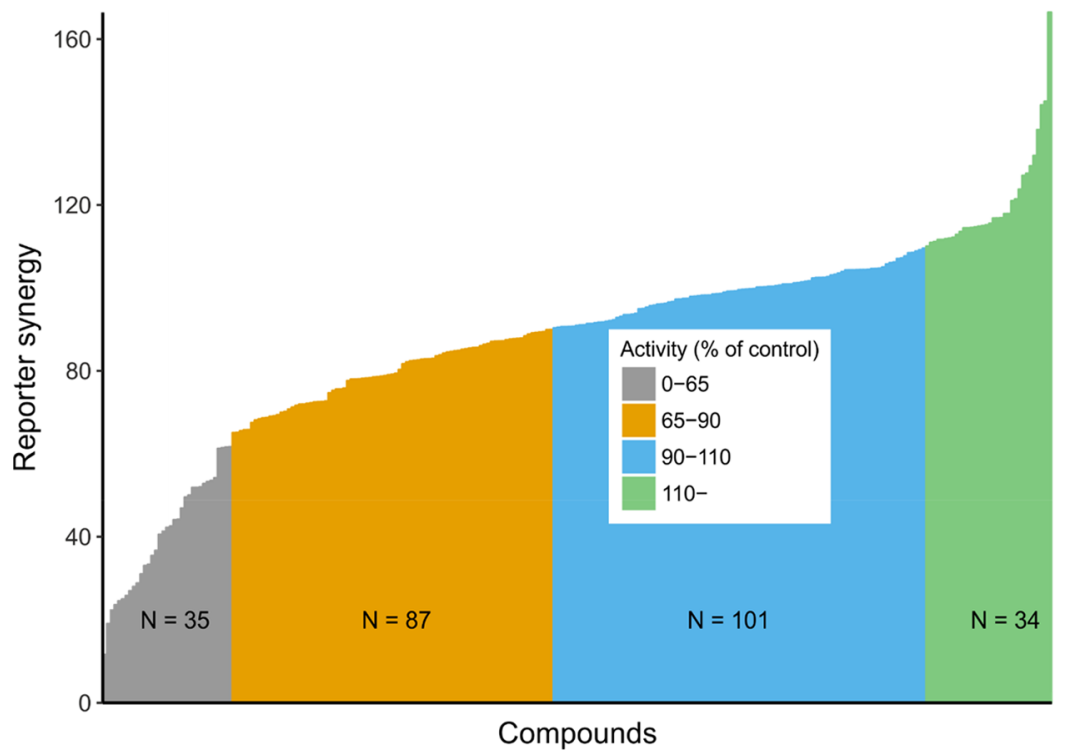

Figure 6. Activity of 257 compounds in the GATA4-NKX2-5 transcriptional synergy assay at the concentration of $10 \mu \mathrm{M}$. Color codes: gray (0$65 \%$ of control), orange ( $65-90 \%$ of control), blue (90-110\% of control), and green ( $110-250 \%$ of control).

GATA4 transcriptional inhibitory activity of the phenylethylsubstituted triazole $\mathbf{7 1}$, ranked in the third place in Table 7 , should be mentioned. This compound also inhibited the NKX2-5 gene transcription (Table 8), but is not ranked among the 10 most potent inhibitors of GATA4-NKX2-5 synergy (Table 6). This finding hints that the chemical space around the region of the 5-methyl group at the isoxazole core in $\mathbf{1}$ is limited, when the GATA4-NKX2-5 interaction is targeted, while it is less critical for interaction with either GATA4 or NKX2-5 alone. The transcriptional enhancing properties of the chromen-4-one bis-isoxazole derivative 73 are interesting. The chromen-4-one derivative $\mathbf{4 g}$ (Table 4 ), derived from the hit structure 1 by a formal exchange of the northern part, inhibits GATA4-NKX2-5 transcriptional synergy, and likewise the bisisoxazole 3 (Table 1), formally derived from $\mathbf{1}$ by an exchange of the southern part, retained inhibiting potency. The combination of both replacements in 73 highlights the difficulties in interpreting SAR. Changes in different regions of a hit compound are not necessarily additive. In this case, the combination of two structural modifications with inhibiting effects turned the biological activity into the opposite and yielded a weak enhancer in the GATA4 transcriptional assay. The same applies to compound 74. While the formal exchange of the northern and southern parts of $\mathbf{1}$ in $4 \mathbf{i}$ and 3 , respectively, yielded inhibitors, the combination of both replacements gave the derivative $\mathbf{7 4}$ with enhancing effects in the GATA4 assay.

Cardiomyocyte Study. Five compounds (GATA4-NKX2-5 synergy inhibitors 1, 61, and 65; the synergy activator 2; and the NKX2-5 activity inhibitor $47 \mathrm{c}$ ) were selected for studies in neonatal cardiomyocytes, which were treated with endothelin1 (ET-1), a well-established hypertrophic agonist that activates the gene expression of both ANP and BNP (Figure 4). The myocytes were transfected with construct containing $-534 /+4$ proximal region of rat BNP promoter with GATA4 and NKX25 binding sites in front of luciferase before exposure to compounds and ET-1, which was added $1 \mathrm{~h}$ after the compounds. The most potent enhancer of the GATA4 gene transcription and synergy activation, compound 2 (Table 6), increased BNP promoter activity, while the most potent inhibitor of the transcriptional synergy (61, Table 6) most strongly inhibited the BNP promoter activity in cardiomyocytes. ET-1 produced about a 3-fold increase in BNP gene activity in this assay, and compound $\mathbf{6 1}$ was the most potent inhibitor of the hypertrophic response at the $30 \mu \mathrm{M}$ concentration. The inhibitor of NKX2-5 activity (47c) increased BNP promoter activity in cardiomyocytes (Figure 4).

Cytotoxicity. To investigate the toxicity as a potential cause of decreased or increased activity in luciferase reporter gene assays, we tested a set of 40 active compounds in the COS-1 cell line used for the luciferase assays. Concentrationdependent toxic effects were investigated using the lactate dehydrogenase $(\mathrm{LDH})$ assay to detect necrosis and the 3-(4,5dimethylthiazol-2-yl)-2,5-diphenyltetrazolium bromide (MTT) assay as a measure of cell viability. None of the test compounds induced necrosis: $\mathrm{LDH}$ release was always less than $8 \%$ (Figure $5 \mathrm{~A})$. In addition, while most of the compounds were nontoxic in the MTT assay (Figure 5B), some of the compounds decreased COS-1 cell viability. For the data analysis, compounds were classified as toxic (Figures 5 and 7) if they induced a $>10 \%$ decrease in cell viability in the MTT assay at the concentration of $10 \mu \mathrm{M}$. The most toxic compounds (35a, 35d, 54, 58, and 63-65) in the MTT assay all contained a phenyl substituent in the southern part ring, while the orthonitrophenyl-derivative $39 \mathrm{~g}$ and the phenyl-substituted thiophene $47 \mathrm{t}$ were nontoxic. Higher flexibility in the central parts of the ethers $(35 a, 35 d)$ and $\mathrm{N}$-acylated amines $(58,64)$ might contribute to their toxicity, because less rigid compounds are more likely to have affinity to various biological targets. Such interactions can cause toxicity. To confirm and validate the results from MTT assays, we tested three nontoxic $(2,47 \mathrm{~s}$, and 72) and three toxic (1, 35a, and 58) compounds in a cell viability assay measuring intracellular ATP content. The ATP assay results are in agreement with the MTT data with compounds 1, 35a, and 58 reducing cell viability more than $10 \%$ at $10 \mu \mathrm{M}$ and compounds $2,47 \mathrm{~s}$, and 72 exhibiting no toxicity (Figure 5C).

Data Analysis. As shown by GATA4 and NKX2-5 luciferase reporter gene and MTT assays, modulation of GATA and NKX2-5 transcriptional activities or cytotoxicity 

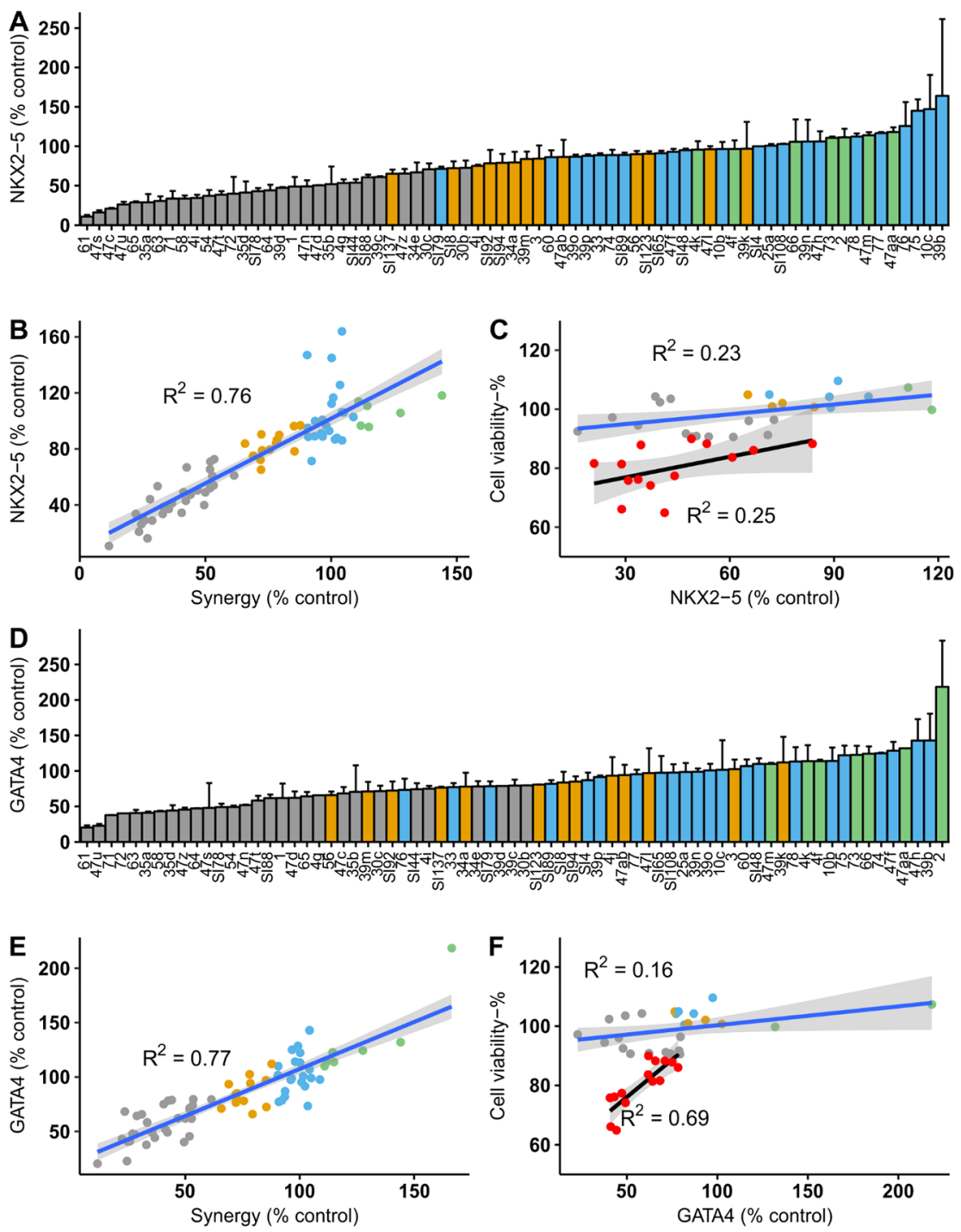

Figure 7. (A) NKX2-5 luciferase reporter gene activity. (B) Relationship between the NKX2-5 luciferase reporter gene activity and the activity on the GATA4-NKX2-5 transcriptional synergy. (C) Relationship between the cell viability in the MTT assay and the NKX2-5 luciferase reporter gene activity. (D) GATA4 luciferase reporter gene activity. (E) Relationship between the GATA4 luciferase reporter gene activity and the activity on the GATA4-NKX2-5 transcriptional synergy. (F) Relationship between the cell viability in the MTT assay and the NKX2-5 luciferase reporter gene activity. Gray area: 95\% confidence level interval for linear model predictions. Blue line (B and E): Linear model for whole data set. Blue line (C and F): Linear model for nontoxic compounds (cell viability >90\%). Red spots: Toxic compounds (cell viability <90\%). Black line: Linear model for toxic compounds (cell viability $<90 \%$ ). Compounds were tested in all assays at the concentration of $10 \mu \mathrm{M}$.

may influence the activity of the compounds on the GATA4NKX2-5 transcriptional synergy. To facilitate data visualization, compounds were divided into four groups on the basis of their activity in the GATA4-NKX2-5 transcriptional synergy assay (Figure 6): compounds (i) increasing synergy (>110\% of GATA4 and NKX2-5 control); (ii) having no effect on synergy (90-110\% of GATA4 and NKX2-5 control); (iii) decreasing synergy $(90-65 \%$ of GATA4 and NKX2-5 control); or (iv) decreasing synergy below the combined mean value of NKX2-5 control in all experiments $(65 \%$ of GATA4 and NKX2-5 control; see Figure 3). We hypothesized that compounds with the luciferase activity below NKX2-5 control in GATA4-NKX2-5 transcriptional synergy assay would inhibit either NKX2-5 or GATA4 transcriptional activity or might be cytotoxic. Indeed, as shown in Figure 7, there is a correlation between the NKX2-5 luciferase and GATA4NKX2-5 transcriptional synergy reporter gene assays, and 76\% $\left(r^{2}=0.76\right)$ of the variation in transcriptional synergy assay can be explained with NKX2-5 luciferase reporter assay readout. A similar correlation was observed between GATA4 luciferase and transcriptional synergy reporter gene assays $\left(r^{2}=0.77\right)$ (Figure 6D). When toxicities in the MTT assay (concentration $10 \mu \mathrm{M}, 39$ compounds) were compared to NKX2-5 and GATA4 luciferase reporter assay readouts (Figure $7 \mathrm{C}$ and F), toxicities of compounds with the cell viability $>90 \%$ explained $23 \%\left(r^{2}=0.23\right)$ of variability in both NKX2-5 and GATA4 reporter assays. For the most toxic compounds in the MTT assay (the cell viability <90\%), toxicity explained 69\% $\left(r^{2}=\right.$ 0.69) of the variation in the GATA4 luciferase reporter gene assays and $25 \%\left(r^{2}=0.25\right)$ in the NKX2-5 assay. The data were further analyzed with hierarchical clustering to identify compounds with similar activity patterns (see Figure S1 for more details). 


\section{DISCUSSION AND CONCLUSION}

We report the syntheses of 220 drug-like compounds together with a comprehensive SAR analysis using three distinct luciferase reporter assays and focusing on selected molecules in two cell toxicity assays. Additionally, 29 commercial compounds (see Table S1) and 8 previously published compounds were tested and used in the SAR and data analysis. We observed that reporter gene assays for both GATA4 and NKX2-5 transcriptional activity relatively strongly correlate with the GATA4-NKX2-5 transcriptional synergy assay. The ability of the compounds to interfere with NKX2-5 transcriptional activity was plausible, as the synergistic effect of GATA4 with NKX2-5 was studied by using a promoter containing three NKX2-5 high affinity response elements. However, the correlation between the GATA4 transcriptional and GATA4-NKX2-5 transcriptional synergy assays is not as obvious, because there is no GATA4 binding site in the GATA4-NKX2-5 luciferase reporter assay. One explanation could be allosteric modulation of GATA4, which may alter protein conformation, such as that binding to either DNA or NKX2-5 is attenuated. In our previous study, ${ }^{29}$ however, we reported that the compounds did not have a statistically significant influence on GATA4 or NKX2-5 DNA binding based on an electrophoretic mobility shift assay. Yet, other direct or indirect molecular mechanisms or the presence of GATA4 in COS- 1 cells may influence GATA4 transcriptional activity.

The SAR analysis showed that methyl substituent (located at position 1 in the reference structure $\mathbf{1}$ ) is not a required feature and that an aromatic or heteroaromatic isoxazole substituent (located at position 3 in the reference structure 1) is often beneficial, but not essential, because also compounds such as 61 with a plain isothiazole were active, for the inhibition of GATA4-NKX2-5 transcriptional synergy. This inhibition was not dominated by the electronic effect of the phenyl ring substituent. It has been shown that the properties of a heterocycle such as its dipole moment and orientation constraints have a major impact on binding affinity through $\pi-\pi$ interaction. $^{38}$ Interestingly, thiophene in $39 \mathrm{~m}$ was a potent ring replacement for the phenyl ring in $\mathbf{1}$, possibly mimicking low energy conformation, in the transcriptional synergy assay for GATA4 and NKX2-5. The thiophene substituent may form intra- or intermolecular noncovalent bonds to $\pi$-systems or electron donors with its electrondeficient sulfur's low-lying $\sigma^{*}$ orbitals of the $\mathrm{C}-\mathrm{S}$ bond. ${ }^{39}$ This view may explain why the corresponding furan derivative 39n does not have a similar activity. Furthermore, the SAR analysis emphasized the previously assumed ${ }^{29}$ importance of a hydrogen-bond acceptor in the northern part of the compounds. Interestingly, the two nitrile-substituted compounds $\mathbf{3 5} \mathbf{a}$ and $\mathbf{3 5 b}$ were effective in the GATA4 and NKX25 transcriptional synergy assay. Nitrile is a known carbonyl isostere $^{40}$ further underlining the significance of hydrogenbond acceptor(s), donors, or otherwise polar groups in the northern part of the compounds. Additionally, ether linkage and $\mathrm{N}$-acylated amides in the central part were tolerated, although free rotation of the central part might enhance the susceptibility of compounds for unspecific binding. The steric demand of $\mathrm{N}$-alkylated amides may increase noncoplanarity of the isoxazole and the aromatic unit in the northern part. An ether linkage is more flexible and allows noncoplanar orientations at lower conformational energy costs. The activity of the $\mathrm{N}$-alkylated amides in the central part and the etherlinked compounds thus hints that the optimal orientation of isoxazole and aromatic moiety in the northern part may not be fully coplanar. In addition, we noticed that heteroatom with a lone pair of electrons capable of acting as a hydrogen-bond acceptor in the positions that correspond to the isoxazole nitrogen or oxygen in $\mathbf{1}$ was seen both in inhibitors and in enhancers, which would indicate that it plays a role in a binding affinity of respective compounds.

It is also noteworthy to point out that a biophysical binding assay would further advance understanding of both the protein-ligand interaction and the molecular mechanism leading to alteration in protein function. Because of the importance of the physical binding data, we have applied a number of experimental approaches, including nuclear magnetic resonance (NMR) and microscale thermophoresis (MST), to study the protein-ligand binding in more detail. However, these experimental methods require large amounts of pure protein, and so far GATA4 protein instability has turned out to be a major challenge (unpublished observation). Moreover, the computational models for the evaluation of ligand binding may guide and advance the ligand optimization and the generation of research hypotheses and, at best, directly estimate the experimentally measured ligand affinities. Because of inaccuracies generally linked to protein models as such, and the lack of specific experimental ligand binding data in this particular study, we have not included docking and molecular dynamics studies into this work. Instead of relying on computational models alone, we are aiming to gather the required experimental support for more complete insight.

The use of luciferase reporter assays has been associated with several limitations. Compounds may aggregate, enzymatically inhibit the reporter, have redox behavior, form fluorescence interfering complexes, interfere with the luciferases, and reduce assay signal, leading to detection of false positives. ${ }^{41}$ However, because the compounds with very similar structures tested herein were either increasing or decreasing signal of GATA4 and NKX2-5 transcriptional activity, inhibition of the luciferase reporters resulting in false positives is unlikely in the current work. Because GATA4 has an essential role in cardiomyocyte cell survival, ${ }^{7}$ we investigated the toxicity of a selected set of 40 compounds targeting GATA4 and NKX2-5 transcriptional synergy in COS-1 cells used in all luciferase reporter assays. As none of the compounds induced significant necrosis, and many had no effect at all on COS-1 cell viability, a rigorous threshold for classifying compounds as toxic was set at $90 \%$ cell viability at the concentration of $10 \mu \mathrm{M}$ in the MTT assay. This gave us also a method to validate the luciferase reporter assay findings. Interestingly, we observed a $69 \%$ correlation between GATA4 transcriptional activity and MTT cell viability for compounds, which showed over $90 \%$ toxicity, suggesting that the inhibition of GATA4 transcriptional activity may play a role in COS-1 cell viability. The concentration-response toxicity data identified three particularly toxic groups of compounds, that is, ether-linked compounds, $\mathrm{N}$-acylated amines, and compounds with reversed substition pattern at the isoxazole ring. Shared structural motive for these compounds is a phenyl substituent at the isoxazole ring. This finding is in line with our previous study, in which the southern part of such molecules was reported to be most likely responsible of toxicity. ${ }^{33}$ In addition, electronic effects and rotational constraints of benzene ring might contribute to toxicity of the compounds. 
The respective compounds are, however, not unsuitable for further optimization a priori, because binding to other cellular targets can be diminished or prevented by additional structural modifications, which do not affect or strengthen affinity to GATA4, NKX2-5, or both.

We have previously reported ${ }^{31}$ that one inhibitor of the GATA4-NKX2-5 interaction (compound 1) had beneficial effects on cardiac function and gene expression in several experimental models of myocardial ischemia and pressure overload in mice and rats, implicating that modulators of the GATA4-NKX2-5 interaction may present a new class of pharmaceuticals for myocardial remodeling and repair. We have also tested the effects of some of these compounds in various hypertrophy assays. ${ }^{29,31}$ The compounds either augmented or inhibited the ET-1-induced increase in ANP and BNP mRNA levels in cardiomyocytes, consistent with the inhibition or activation of the GATA4-NKX2-5 interaction. ${ }^{29}$ Mechanical stretch also induces hypertrophic growth of the cardiac myocytes, as reflected by the increase of cardiomyocyte cell size and activation of the ANP and BNP genes, and we reported that compound $\mathbf{1}$ significantly reduced the increase in the area of the cardiomyocytes and ANP and BNP mRNA levels in response to mechanical stretch. ${ }^{29,31}$ Moreover, compound 1 significantly inhibited ANP and BNP gene expression induced by another hypertrophic agonist phenylephrine. ${ }^{31}$ In the present study, we selected several compounds for studies in cardiomyocytes, which were treated with ET-1, and analyzed the hypertrophic response as the activation of BNP gene transcription. In agreement with the results using artificial luciferase reporter vector with three high affinity binding sites for NKX2-5, the most potent enhancer of the GATA4-NKX2-5 synergy activation (compound 2) increased BNP promoter activity, while the most potent inhibitor (compound 61) of the GATA4-NKX2-5 transcriptional synergy strongly inhibited the BNP promoter activity in cardiomyocytes. ET-1 produced about a 3-fold increase in BNP gene activity, and compound 61 was again the most potent inhibitor of the hypertrophic response. Overall, our current and previous results show that the compounds acting on GATA4-NKX2-5 transcriptional synergy can modulate the hypertrophic response in cardiomyocytes in vitro and that the most potent compounds inhibiting transcriptional synergy of GATA4 and NKX2-5 possess the greatest therapeutic potential.

Transcription factors are the central regulators of gene expression, and their protein-protein interactions are of pivotal importance in the regulation of biological systems. Thus, the modulation of interactions of transcription factors has potential to become one of the next major classes of therapeutic targets. Cardiac transcription factors GATA4 and NKX2-5 directly interact and synergistically activate several genes and stretch-induced cardiomyocyte hypertrophy. Our comprehensive SAR analysis of more than 200 structurally related compounds accompanied by a data analysis successfully identified inhibitors of the activity of GATA4-NKX2-5 transcriptional synergy as well as the most potent molecular structures for the inhibition of GATA4-NKX2-5 synergy without cellular toxicity or effect on either NKX2-5 or GATA4 transcriptional activity. In further experiments, it would be interesting to investigate the effects of the compounds with distinct actions on GATA4-NKX2-5 transcriptional synergy in the in vitro and in vivo experimental models of cardiac remodeling and regeneration. A more detailed assessment of the molecular mechanism(s) of action of these modulators of GATA4-NKX2-5 interactions is also needed to determine whether synergy inhibitors directly bind to GATA4 or act by some other mechanisms. In any case, the identified bioactive compounds inhibiting synergistic GATA4 and NKX2-5 gene activation may have potential as leads for further drug development for the treatment of heart failure.

In conclusion, we have identified potent and selective inhibitors of GATA4-NKX2-5 transcriptional synergy and revealed structural features important for it. Therapeutical potential of the most potent synergy inhibitors is exemplified by their ability to inhibit hypertrophic gene expression response in primary rat cardiomyocytes.

\section{EXPERIMENTAL SECTION}

General Procedures (Chemistry). All reactions were carried out using commercially available starting materials and reagents. Structures and syntheses of compounds SI1-136 are shown in the Supporting Information. Compound $\mathbf{1}$ was purchased from Pharmatory Ltd. (Oulu, Finland). Compounds SI120-130 and 59 were purchased from Enamine (Kiev, Ukraine), compounds 57, 70, and SI113 were from ChemBridge (San Diego, CA), compounds 66, 69, and SI114-119 were from ChemDiv (San Diego, CA), and compounds SI133-136 were from Maybridge (Leicestershire, UK). All chemicals, solvents, and anhydrous solvents used in the syntheses were acquired from Sigma-Aldrich (Schnelldorf, Germany), Fluka (Buchs, Switzerland), and Alfa Aesar (Ward Hill, MA). All moisturesensitive reactions were performed in flame-dried glassware under an inert argon atmosphere. The progress of chemical reactions was monitored by thin-layer chromatography on $0.2 \mathrm{~mm}$ silica gel plates (silica gel 60, F254, Merck KGaA, Darmstadt, Germany) and visualized by UV light or ninhydrin stain ( $1.5 \%$ by weight in ethanol), when applicable. Column chromatography was performed with automated Biotage high performance flash chromatography Sp4system (Uppsala, Sweden) using a $0.1 \mathrm{~mm}$ path length flow cell UVdetector/recorder module (fixed wavelength $254 \mathrm{~nm}$ ) and the indicated mobile phase. The melting points were recorded with an SMP40 automatic melting point apparatus (Bibby Scientific Limited, Staffordshire, UK) and are uncorrected. Nuclear magnetic resonance spectra $\left({ }^{1} \mathrm{H}\right.$ NMR and ${ }^{13} \mathrm{C}$ NMR $)$ were recorded on a Varian Mercury Plus 300 (Agilent Technologies, Santa Clara, CA) or a Bruker Ascend 400-Avance III HD NMR spectrometer (Bruker Corp., Billerica, MA), ${ }^{1} \mathrm{H}$ NMR spectra at 300 or $400 \mathrm{MHz}$, and ${ }^{13} \mathrm{C}$ NMR spectra at 75 or $101 \mathrm{MHz}$. Chemical shifts $(\delta)$ are reported in parts per million (ppm) relative to the NMR solvent signals $\left(\mathrm{CDCl}_{3} 7.26\right.$ and $77.16 \mathrm{ppm}$, DMSO- $d_{6} 2.50$ and $39.50 \mathrm{ppm}$, for ${ }^{1} \mathrm{H}$ and ${ }^{13} \mathrm{C}$ NMR, respectively). When necessary, two-dimensional NMR experiments (COSY, NOESY, gHSQC, gHMBC) were conducted to support structure determination. Multiplicities are indicated by s (singlet), d (doublet), $\mathrm{dd}$ (doublet of dublets), $\mathrm{t}$ (triplet), q (quartet), and sept (septet). The additional letter "b" indicates a broad signal, such as bs (broad singlet). Multiplets $(\mathrm{m})$ are either reported as a range of $\mathrm{ppm}$ values $(\mathrm{m})$ or as a centered multiplet $\left(\mathrm{m}_{\mathrm{c}}\right)$. Coupling constants $J$ are quoted in hertz $(\mathrm{Hz})$. Exact mass and purity $(>95 \%)$ of all tested compounds were confirmed by LC-MS analyses with a Waters Acquity UPLC system (Waters, Milford, MA) equipped with an Acquity UPLC BEH C18 column $(1.7 \mu \mathrm{m}, 50 \mathrm{~mm} \times 2.1 \mathrm{~mm}$, Waters, Ireland $)$, an Acquity PDA detector, and a Waters Synapt G2 HDMS mass spectrometer (Waters, Milford, MA) via an ESI ion source in positive mode. Highresolution mass (HRMS-ESI) data were reported for the molecular ions $[\mathrm{M}+\mathrm{H}]^{+}$.

General Synthetic Procedures. See the Supporting Information for more details.

5-Methyl-N-(3-oxo-2,3-dihydro-1H-inden-5-yl)-3-phenylisoxazole-4-carboxamide (4a). Synthesis was done according to general procedure I. Deviating from general procedure I, two subsequent chromatographic purifications were conducted, because the first chromatography did not give complete separation. 5-Methyl-3- 
phenylisoxazole-4-carboxylic acid ( $50.3 \mathrm{mg}, 0.248 \mathrm{mmol}), 6$-aminoindanone (36.4 mg, $0.248 \mathrm{mmol}$ ), HBTU (122 mg, $0.322 \mathrm{mmol}, 1.3$ equiv), DIPEA ( $86.4 \mathrm{~mL}, 0.496 \mathrm{mmol}, 2$ equiv), and DMF ( $2 \mathrm{~mL})$. Solvent for extraction: ethyl acetate and water. Recrystallization $\left(\mathrm{MeOH} / \mathrm{H}_{2} \mathrm{O} 10+1\right)$ after chromatography on silica gel gave compound $4 \mathrm{a}(20.3 \mathrm{mg}, 0.0611 \mathrm{mmol}, 25 \%)$ as a beige solid. $\mathrm{Mp}$ 219.1-223.1 ${ }^{\circ} \mathrm{C} .{ }^{1} \mathrm{H}$ NMR $\left(300 \mathrm{MHz}, \mathrm{DMSO}-d_{6}\right): \delta 10.59(\mathrm{~s}, 1 \mathrm{H})$, $8.00(\mathrm{~d} \approx \mathrm{s}, 1 \mathrm{H}), 7.77\left(\mathrm{dd}, 1 \mathrm{H},{ }^{4} J=2.1 \mathrm{~Hz},{ }^{3} \mathrm{~J}=8.3 \mathrm{~Hz}\right), 7.72-7.65$ $(\mathrm{m}, 2 \mathrm{H}), 7.56(\mathrm{~d}, 1 \mathrm{H}), 7.52-7.44(\mathrm{~m}, 3 \mathrm{H}), 3.10-3.03(\mathrm{~m}, 2 \mathrm{H})$, $2.69-2.63(\mathrm{~m}, 2 \mathrm{H}), 2.60(\mathrm{~s}, 3 \mathrm{H}) \mathrm{ppm} .{ }^{13} \mathrm{C}$ NMR $(75 \mathrm{MHz}$, DMSO$\left.d_{6}\right): \delta 206.0,170.1,160.2,150.7,137.8,137.0,130.1,128.8,127.9$, $127.7,127.2,126.4,113.1,113.0,36.3,25.0,11.9$ ppm. HRMS calcd for $\mathrm{C}_{20} \mathrm{H}_{16} \mathrm{~N}_{2} \mathrm{O}_{3}[\mathrm{M}+\mathrm{H}]^{+}$, 333.1239; found, 333.1245.

$\mathrm{N}$-[4-(Dimethylamino)phenyl]-5-methyl-3-phenylisoxazole-4carboxamide (4d). Synthesis was done according to general procedure I. Deviating from general procedure I, the reaction mixture was diluted with ethyl acetate for the workup and extracted five times with $2 \mathrm{M}$ hydrochloric acid. The combined aqueous phases were made alkaline with a $2 \mathrm{M}$ solution of sodium hydroxide in water and extracted with ethyl acetate. The organic phase was washed twice with a mixture of water and brine (10:1). 5-Methyl-3-phenylisoxazole-4carboxylic acid $(0.100 \mathrm{~g}, 0.492 \mathrm{mmol}), \mathrm{N}, \mathrm{N}$-dimethyl-p-phenylenediamine $(67.0 \mathrm{mg}, 0.492 \mathrm{mmol})$, HBTU ( $558 \mathrm{mg}, 1.48 \mathrm{mmol}, 3$ equiv), DIPEA (0.257 mL, $1.48 \mathrm{mmol}, 3$ equiv), and DMF $(2.5 \mathrm{~mL})$. Recrystallization $\left(\mathrm{MeOH} / \mathrm{H}_{2} \mathrm{O} 10+1\right)$ [without chromatography on silica gel] gave compound $4 \mathrm{~d}(57.0 \mathrm{mg}, 0.177 \mathrm{mmol}, 36 \%)$ as gray plates. Mp 159.5-160.1 ${ }^{\circ} \mathrm{C} .{ }^{1} \mathrm{H}$ NMR $\left(300 \mathrm{MHz}, \mathrm{DMSO}-d_{6}\right): \delta$ $10.14(\mathrm{~s}, 1 \mathrm{H}), 7.75-7.68(\mathrm{~m}, 2 \mathrm{H}), 7.53-7.40(\mathrm{~m}, 3 \mathrm{H}),, 7.43\left(\mathrm{~m}_{\mathcal{c}}\right.$ $2 \mathrm{H}), 6.71\left(\mathrm{~m}_{\mathrm{c}}, 2 \mathrm{H}\right), 2.85(\mathrm{~s}, 6 \mathrm{H}), 2.56(\mathrm{~s}, 3 \mathrm{H}) \mathrm{ppm} .{ }^{13} \mathrm{C}$ NMR $(75$ MHz, DMSO- $\left.d_{6}\right): \delta 169.4,160.1,159.2,147.6,130.1,128.8,128.3$, 128.2, 127.7, 121.1, 113.6, 112.6, 11.9 ppm. HRMS calcd for $\mathrm{C}_{19} \mathrm{H}_{20} \mathrm{~N}_{3} \mathrm{O}_{2}[\mathrm{M}+\mathrm{H}]^{+}$, 322.1556; found, 322.1553.

$\mathrm{N}$-[4-[Ethyl(isopropyl)amino]phenyl]-5-methyl-3-phenylisoxazole-4-carboxamide (4i). Synthesis was done according to general procedure I. Deviating from general procedure I, the reaction mixture was stirred at room temperature for $3 \mathrm{~d}$. 5-Methyl-3-phenylisoxazole4-carboxylic acid 6 (2.03 g, $10.0 \mathrm{mmol})$ : $\mathrm{N}$-ethyl- $\mathrm{N}$-isopropylphenylenediamine hydrochloride $(2.15 \mathrm{~g}, 10.0 \mathrm{mmol}), \mathrm{HBTU}(4.17 \mathrm{~g}, 11.0$ mmol, 1.1 equiv), DIPEA ( $2.61 \mathrm{~mL}, 15.0 \mathrm{mmol}, 1.5$ equiv $)$, and DMF $(25 \mathrm{~mL})$. Solvent for extraction: ethyl acetate. Recrystallization $\left(\mathrm{MeOH} / \mathrm{H}_{2} \mathrm{O} 15+1\right)$ after chromatography on silica gel gave compound $4 \mathrm{i}(1.59 \mathrm{~g}, 4.37 \mathrm{mmol}, 44 \%)$ as colorless crystals. Mp $130.5-132.6{ }^{\circ} \mathrm{C} .{ }^{1} \mathrm{H}$ NMR $\left(300 \mathrm{MHz}, \mathrm{DMSO}-d_{6}\right): \delta 10.08(\mathrm{~s}, 1 \mathrm{H})$, 7.75-7.68 (m, 2H), 7.53-7.45 (m, 3H,), $7.41\left(\mathrm{~m}_{\mathrm{c}}, 2 \mathrm{H}\right), 6.70\left(\mathrm{~m}_{\mathrm{c}}\right.$ $2 \mathrm{H}), 3.97\left(\mathrm{sep}, 1 \mathrm{H},{ }^{3} \mathrm{~J}=6.6 \mathrm{~Hz}\right), 3.19\left(\mathrm{q}, 2 \mathrm{H},{ }^{3} \mathrm{~J}=7.0 \mathrm{~Hz}\right), 2.56(\mathrm{~s}$, $3 \mathrm{H}), 1.12(\mathrm{~d}, 6 \mathrm{H}), 1.07(\mathrm{t}, 3 \mathrm{H}) \mathrm{ppm} .{ }^{13} \mathrm{C}$ NMR $(75 \mathrm{MHz}, \mathrm{DMSO}-$ $\left.d_{6}\right): \delta 169.3,160.0,159.0,145.1,130.0,128.7,128.2,127.6,121.4$, 113.6, 113.0, 48.0, 37.4, 19.8, 14.8, 11.9 ppm. HRMS calcd for $\mathrm{C}_{22} \mathrm{H}_{26} \mathrm{~N}_{3} \mathrm{O}_{2}[\mathrm{M}+\mathrm{H}]^{+}$, 364.2025; found, 364.2025.

5-Methyl-3-phenyl-N-[4-[(trimethylsilyl)ethynyl]phenyl]isoxazole-4-carboxamide (4j). Synthesis was done according to general procedure I. Deviating from general procedure I, the reaction mixture was diluted with ethyl acetate for the workup and extracted in the following order: once with water containing $10 \%$ brine, once with a $2 \mathrm{M}$ solution of sodium hydroxide in water, twice with $2 \mathrm{M}$ hydrochloric acid, and several times with water until the water phase remained neutral. 5-Methyl-3-phenylisoxazole-4-carboxylic acid 6 (203 mg, $1.00 \mathrm{mmol}): 4$-[(trimethylsilyl)ethynyl]aniline $(189 \mathrm{mg}$, $1.00 \mathrm{mmol}$ ), HBTU (569 mg, $1.50 \mathrm{mmol}, 1.5$ equiv), DIPEA (0.523 $\mathrm{mL}, 3.00 \mathrm{mmol}, 3$ equiv), and DMF $(4 \mathrm{~mL})$. After automated chromatography on silica gel, which only gave partial separation, the crude product was recrystallized once by slow evaporation of methanol and once from $\mathrm{MeOH} / \mathrm{H}_{2} \mathrm{O}(10+1)$ to yield compound 4j (64 mg, $0.17 \mathrm{mmol}, 17 \%)$ as white needles. Mp 143.5-144.3 ${ }^{\circ} \mathrm{C}$. ${ }^{1} \mathrm{H}$ NMR (300 MHz, DMSO- $\left.d_{6}\right): \delta 10.62(\mathrm{~s}, 1 \mathrm{H}), 7.70-7.60(\mathrm{~m}$, $4 \mathrm{H}), 7.52-7.41(\mathrm{~m}, 5 \mathrm{H}), 2.58(\mathrm{~s}, 3 \mathrm{H}), 0.22(\mathrm{~s}, 9 \mathrm{H}) \mathrm{ppm} .{ }^{13} \mathrm{C} \mathrm{NMR}$ $\left(75 \mathrm{MHz}, \mathrm{DMSO}-d_{6}\right): \delta 170.2,160.3,160.1,139.2,132.4,130.1$, $128.9,127.9,127.8,119.5,117.4,113.1,105.2,93.4,12.0,0.03$ ppm. HRMS calcd for $\mathrm{C}_{22} \mathrm{H}_{23} \mathrm{~N}_{2} \mathrm{O}_{2} \mathrm{Si}[\mathrm{M}+\mathrm{H}]^{+}, 375.1529$; found, 375.1525 .
$\mathrm{N}$-[4-(tert-Butyl)thiazol-2-yl]-5-methyl-3-phenylisoxazole-4-carboxamide (4k). Synthesis was done according to general procedure I. 5-Methyl-3-phenylisoxazole-4-carboxylic acid $(60.0 \mathrm{mg}, 0.295 \mathrm{mmol})$, 4-(tert-butyl)thiazol-2-amine $5 \mathrm{k}$ ( $50.8 \mathrm{mg}, 0.325 \mathrm{mmol}, 1.1$ equiv), HBTU (146 mg, $0.384 \mathrm{mmol}, 1.3$ equiv), DIPEA (0.103 mL, 0.591 mmol, 2 equiv), and DMF $(2 \mathrm{~mL})$. Solvent for extraction: diethyl ether. Chromatography on silica gel gave compound $4 \mathbf{k}(68.9 \mathrm{mg}$, $0.0201 \mathrm{mmol}, 68 \%)$ as a white solid. Mp 198.3-203.0 ${ }^{\circ} \mathrm{C} .{ }^{1} \mathrm{H}$ NMR $\left(300 \mathrm{MHz}, \mathrm{DMSO}-d_{6}\right): \delta 12.60(\mathrm{~s}, 1 \mathrm{H}), 7.66-7.58(\mathrm{~m}, 2 \mathrm{H}), 7.54-$ $7.47(\mathrm{~m}, 3 \mathrm{H}), 6.83(\mathrm{~s}, 1 \mathrm{H}), 2.59(\mathrm{~s}, 3 \mathrm{H}), 1.26(\mathrm{~s}, 9 \mathrm{H}) .{ }^{13} \mathrm{C}$ NMR $(75$ $\left.\mathrm{MHz}, \mathrm{DMSO}-d_{6}\right): \delta 170.9,160.4,159.8,156.8,130.0,128.8,128.4$, 128.1, 128.0, 127.8, 111.3, 105.3, 34.1, 29.7, 12.1. HRMS calcd for $\mathrm{C}_{18} \mathrm{H}_{20} \mathrm{~N}_{3} \mathrm{O}_{2} \mathrm{~S}[\mathrm{M}+\mathrm{H}]^{+}$, 342.1276; found, 342.1278.

4-(tert-Butyl)thiazol-2-amine (5k). 1-Bromopinacolone 14 (0.134 $\mathrm{mL}, 1.00 \mathrm{mmol})$ and thiourea $(76.0 \mathrm{mg}, 1.00 \mathrm{mmol})$ were dissolved in ethanol $(2 \mathrm{~mL})$. The suspension was irradiated via microwave at 120 ${ }^{\circ} \mathrm{C}$ for $30 \mathrm{~min}$. The resulting greenish solution was poured into a $1 \mathrm{M}$ solution of sodium hydroxide in water $(25 \mathrm{~mL})$ and extracted with dichloromethane $(3 \times 20 \mathrm{~mL})$. The combined organic phases were washed with brine $(20 \mathrm{~mL})$ and dried over anhydrous $\mathrm{Na}_{2} \mathrm{SO}_{4}$. Solvents were removed in vacuo to yield compound $5 \mathrm{k}(132 \mathrm{mg}$, $0.845 \mathrm{mmol}, 85 \%) .{ }^{1} \mathrm{H}$ NMR $\left(300 \mathrm{MHz}, \mathrm{CDCl}_{3}\right): \delta 6.08(\mathrm{~s}, 1 \mathrm{H})$, $5.05(\mathrm{~s}, 2 \mathrm{H}), 1.26(\mathrm{~s}, 9 \mathrm{H})$.

$N$-Ethyl-N-isopropyl-N-methyl-4-(5-methyl-3-phenylisoxazole-4carboxamido)benzenaminium lodide (7). $\mathrm{N}$-[4-[Ethyl(isopropyl)amino]phenyl]-5-methyl-3-phenylisoxazole-4-carboxamide 4i (364 $\mathrm{mg}, 1.00 \mathrm{mmol}$ ) was dissolved in dry methanol $(3 \mathrm{~mL})$. Iodomethane $(74.7 \mu \mathrm{L}, 1.20 \mathrm{mmol})$ was added, and the reaction mixture was heated at $100{ }^{\circ} \mathrm{C}$ in a microwave reactor for $8 \mathrm{~h}$. The solvent was removed with a rotary evaporator. The residue was dissolved in an equimixture of ethyl acetate and diethyl ether, and extracted three times with a small amount of water. The combined aqueous phases were washed twice with an equimixture of ethyl acetate and diethyl ether. Water was removed with a rotary evaporator, and the crude product was recrystallized from ethanol to give compound $7(55.0 \mathrm{mg}, 0.109$ mmol, $11 \%$ ) as beige needles. Mp $132.4-134.2{ }^{\circ} \mathrm{C}$ (decomp.). ${ }^{1} \mathrm{H}$ NMR $\left(300 \mathrm{MHz}, \mathrm{DMSO}-d_{6}\right): \delta 10.81(\mathrm{~s}, 1 \mathrm{H}), 7.90-7.73(\mathrm{~m}, 4 \mathrm{H})$, $7.73-7.63(\mathrm{~m}, 2 \mathrm{H}), 7.56-7.45(\mathrm{~m}, 3 \mathrm{H}), 4.24\left(\mathrm{qq} \approx \mathrm{sept}, 1 \mathrm{H},{ }^{3} \mathrm{~J}=\right.$ $\left.6.3,{ }^{3} \mathrm{~J}=6.4 \mathrm{~Hz}\right), 4.11-3.98(\mathrm{~m}, 1 \mathrm{H}), 3.95-3.80(\mathrm{~m}, 1 \mathrm{H}), 3.44(\mathrm{bs}$, $3 \mathrm{H}), 2.61(\mathrm{~s}, 3 \mathrm{H}), 1.43(\mathrm{~d}, 3 \mathrm{H}), 1.00(\mathrm{~d}, 3 \mathrm{H}), 0.93(\mathrm{dd} \approx \mathrm{t}, 3 \mathrm{H})$ ppm. ${ }^{13} \mathrm{C}$ NMR $\left(75 \mathrm{MHz}\right.$, DMSO-d $\left.d_{6}\right): \delta 170.4,160.4,160.3,139.5$, 137.0, 130.2, 128.9, 127.9, 127.8, 123.3, 120.3, 112.9, 71.5, 59.2, 40.7, 16.8, 16.4, 12.1, 8.6, ppm. HRMS calcd for the cation $\mathrm{C}_{23} \mathrm{H}_{28} \mathrm{~N}_{3} \mathrm{O}_{2}{ }^{+}$ $[\mathrm{M}]^{+}, 378.2182$; found, 378.2187 .

$\mathrm{N}$-[4-[Ethyl(isopropyl)amino]-3-nitrophenyl]-5-methyl-3-phenylisoxazole-4-carboxamide (8). $N$-[4-[Ethyl(isopropyl)amino] phenyl]-5-methyl-3-phenylisoxazole-4-carboxamide $4 \mathrm{i}(302 \mathrm{mg}$, $0.831 \mathrm{mmol}$ ) was dissolved in absolute acetonitrile $(6 \mathrm{~mL})$ under argon and cooled to $0{ }^{\circ} \mathrm{C}$ in an ice bath. Under anhydrous conditions, nitrosonium tetrafluoroborate $(149 \mathrm{mg}, 1.12 \mathrm{mmol})$ was placed under argon and cooled to $0{ }^{\circ} \mathrm{C}$ in an ice bath. Slowly, the cold acetonitrile solution was added to the solid nitrosonium tetrafluoroborate under argon, and the reaction mixture was stirred for $2 \mathrm{~h}$ at $0{ }^{\circ} \mathrm{C}$. The solvent was removed with a rotary evaporator, and the crude product was subjected to automated preparative chromatography. The chromatography on silica gel with an increasing gradient of ethyl acetate in $n$-hexane, starting with $0 \%$ of ethyl acetate, gave compound $8(44.0 \mathrm{mg}, 0.112 \mathrm{mmol}, 13 \%)$ as an orange resin. ${ }^{1} \mathrm{H}$ NMR (300 MHz, DMSO- $\left.d_{6}\right): \delta 10.73(\mathrm{~s}, 1 \mathrm{H}), 8.11\left(\mathrm{~d}, 1 \mathrm{H},{ }^{4} J=2.5 \mathrm{~Hz}\right), 7.73-$ $7.62(\mathrm{~m}, 3 \mathrm{H}), 7.53-7.45(\mathrm{~m}, 4 \mathrm{H}), 3.22\left(\mathrm{sept}, 1 \mathrm{H},{ }^{3} \mathrm{~J}=6.6 \mathrm{~Hz}\right), 3.02$ $\left(\mathrm{q}, 2 \mathrm{H},{ }^{3} J=7.0 \mathrm{~Hz}\right), 2.60(\mathrm{~s}, 3 \mathrm{H}), 1.02(\mathrm{~d}, 6 \mathrm{H}), 0.84(\mathrm{t}, 3 \mathrm{H}) \mathrm{ppm}$. ${ }^{13} \mathrm{C}$ NMR $\left(75 \mathrm{MHz}\right.$, DMSO- $\left.d_{6}\right): \delta 170.3,160.3,160.1,147.1,138.7$, $133.9,130.2,128.9,127.9,127.8,126.1,123.5,114.8,112.9,54.8$, $39.4,19.5,13.4,12.0 \mathrm{ppm}$. HRMS calcd for $\mathrm{C}_{22} \mathrm{H}_{25} \mathrm{~N}_{4} \mathrm{O}_{4}[\mathrm{M}+\mathrm{H}]^{+}$, 409.1876; found, 409.1895 .

N-[3-Amino-4-[ethyl(isopropyl)amino]phenyl]-5-methyl-3-phenylisoxazole-4-carboxamide (9). $N$-[4-[Ethyl(isopropyl)amino]-3nitrophenyl]-5-methyl-3-phenylisoxazole-4-carboxamide $8(36.0 \mathrm{mg}$, $0.0881 \mathrm{mmol})$ was dissolved in an equimixture of acetic acid and methanol $(0.60 \mathrm{~mL})$. Zinc $(18.0 \mathrm{mg}, 0.275 \mathrm{mmol}, 3$ equiv $)$ was added, 
and the reaction mixture was stirred overnight at room temperature. The reaction mixture was diluted with ethyl acetate and three times with water. The solvent was removed with a rotary evaporator, and the product mixture was purified by automated preparative chromatography. The chromatography on silica gel with an increasing gradient of ethyl acetate in $n$-hexane, starting with $0 \%$ of ethyl acetate, gave compound $9(10.0 \mathrm{mg}, 0.0264 \mathrm{mmol}, 30 \%)$ as a white solid. Mp $111.5-113.2{ }^{\circ} \mathrm{C} .{ }^{1} \mathrm{H}$ NMR $\left(300 \mathrm{MHz}, \mathrm{DMSO}-d_{6}\right): \delta 10.08(\mathrm{~s}, 1 \mathrm{H})$, $7.75-7.67(\mathrm{~m}, 2 \mathrm{H}), 7.53-7.47(\mathrm{~m}, 3 \mathrm{H}), 7.08\left(\mathrm{~d}, 1 \mathrm{H},{ }^{4} \mathrm{~J}=2.4 \mathrm{~Hz}\right)$, $6.90\left(\mathrm{~d}, 1 \mathrm{H},{ }^{3} \mathrm{~J}=8.4 \mathrm{~Hz}\right), 6.74(\mathrm{dd}, 1 \mathrm{H}), 4.86(\mathrm{~s}, 2 \mathrm{H}), 3.08(\mathrm{sept}, 1 \mathrm{H}$, $\left.{ }^{3} J=6.5 \mathrm{~Hz}\right), 2.91\left(\mathrm{q}, 2 \mathrm{H},{ }^{3} J=7.0 \mathrm{~Hz}\right), 2.55(\mathrm{~s}, 3 \mathrm{H}), 1.01(\mathrm{~d}, 6 \mathrm{H})$, $0.81(\mathrm{t}, 3 \mathrm{H})$ ppm. ${ }^{13} \mathrm{C}$ NMR $\left(75 \mathrm{MHz}\right.$, DMSO- $\left.d_{6}\right): \delta 169.3,160.1$, $159.4,146.0,135.1,130.9,130.2,128.8,128.2$, 127.6, 123.8, 113.6, 107.8, 105.8, 51.6, 40.8, 19.6, 13.1, 11.8 ppm. HRMS calcd for $\mathrm{C}_{22} \mathrm{H}_{27} \mathrm{~N}_{4} \mathrm{O}_{2}[\mathrm{M}+\mathrm{H}]^{+}$, 379.2134; found, 379.2141 .

Cyanomethyl 4-(5-Methyl-3-phenylisoxazole-4-carboxamido)benzoate (10a). Synthesis was done according to general procedure X. 4-(5-Methyl-3-phenylisoxazole-4-carboxamido)benzoic acid $\mathbf{1 2}$ (43.1 $\mathrm{mg}, 0.134 \mathrm{mmol})$, bromoacetonitrile $(8.90 \mu \mathrm{L}, 0.134 \mathrm{mmol})$, $\mathrm{K}_{2} \mathrm{CO}_{3}(27.8 \mathrm{mg}, 0.201 \mathrm{mmol}, 1.5$ equiv), and DMF $(1 \mathrm{~mL})$. Reaction time: $2 \mathrm{~d}$. Solvent for extraction: a mixture of diethyl ether and ethyl acetate (1:1) and water. Chromatography on silica gel gave compound $10 \mathrm{a}(28.9 \mathrm{mg}, 0.0800 \mathrm{mmol}, 60 \%)$ as a white solid. $\mathrm{Mp}$ $189.0-190.7^{\circ} \mathrm{C} .{ }^{1} \mathrm{H}$ NMR $\left(300 \mathrm{MHz}\right.$, DMSO- $\left.d_{6}\right): \delta 10.80(\mathrm{~s}, 1 \mathrm{H})$, $7.99\left(\mathrm{~m}_{\mathcal{c}}, 2 \mathrm{H}\right), 7.80\left(\mathrm{~m}_{\mathcal{c}} 2 \mathrm{H}\right), 7.72-7.64(\mathrm{~m}, 2 \mathrm{H}), 7.53-7.45(\mathrm{~m}$, $3 \mathrm{H}), 5.20(\mathrm{~s}, 2 \mathrm{H}), 2.60(\mathrm{~s}, 3 \mathrm{H}) \mathrm{ppm} .{ }^{13} \mathrm{C}$ NMR $(75 \mathrm{MHz}, \mathrm{DMSO}-$ $\left.d_{6}\right): \delta 170.4,164.1,160.4,160.2,143.7,130.8,130.1,128.8,127.8$, $127.7,122.8,119.2,116.0,112.9,49.5,11.9$ ppm. HRMS calcd for $\mathrm{C}_{20} \mathrm{H}_{16} \mathrm{~N}_{3} \mathrm{O}_{4}[\mathrm{M}+\mathrm{H}]^{+}$, 362.1141; found, 362.1139.

Methyl 4-(5-Methyl-3-phenylisoxazole-4-carboxamido)benzoate (11). 5-Methyl-3-phenylisoxazole-4-carboxylic acid (1.50 g, 7.38 $\mathrm{mmol}$ ) was dissolved under argon in an equimixture of absolute dichloromethane and absolute DMF $(4 \mathrm{~mL})$. Oxalyl chloride $(0.687$ $\mathrm{mL}, 8.12 \mathrm{mmol}$, 1.1 equiv) was added under argon stream within 10 $\mathrm{min}$. The reaction mixture was stirred for $30 \mathrm{~min}$ at room temperature and cooled to $0{ }^{\circ} \mathrm{C}$. Absolute pyridine $(5 \mathrm{~mL})$ was added, and after 5 min methyl 4-aminobenzoate $13(1.23 \mathrm{mg}, 8.12 \mathrm{mmol}, 1.1$ equiv) and DMAP (1.35 mg, $11.1 \mathrm{mmol}, 1.5$ equiv) were added. The reaction mixture was stirred for $3 \mathrm{~d}$ at room temperature. Ethyl acetate was added, and the organic phase was washed three times with water. The solvent was removed with a rotary evaporator, and dichloromethane $(5 \mathrm{~mL})$ and acetone $(5 \mathrm{~mL})$ were added. The solvents were decanted, and the residue was dried with a rotary evaporator and recrystallized from hot methanol. Filtration gave compound 11 (742 mg, 2.21 $\mathrm{mmol}, 30 \%)$ as white crystals. The solvent of the mother liquor was removed with a rotary evaporator, and the residue was subjected to automated preparative chromatography. The chromatography on silica gel with an increasing gradient of ethyl acetate in $n$-hexane, starting with $0 \%$ of ethyl acetate, gave compound 11 (121 mg, 0.360 $\mathrm{mmol}$ ) as a white solid, increasing the yield to $843 \mathrm{mg}, 2.51 \mathrm{mmol}$, 34\%. Mp $177.1-179.4{ }^{\circ} \mathrm{C} .{ }^{1} \mathrm{H}$ NMR (300 MHz, DMSO- $d_{6}$ ): $\delta 10.74$ $(\mathrm{s}, 1 \mathrm{H}), 7.96,7.76\left(\right.$ each $\mathrm{m}_{\mathcal{c}}$ each $\left.2 \mathrm{H}\right), 7.72-7.65(\mathrm{~m}, 2 \mathrm{H}), 7.53-$ $7.46(\mathrm{~m}, 3 \mathrm{H}), 3.84(\mathrm{~s}, 3 \mathrm{H}), 2.60(\mathrm{~s}, 3 \mathrm{H}) \mathrm{ppm} .{ }^{13} \mathrm{C} \mathrm{NMR}(75 \mathrm{MHz}$, DMSO- $\left.d_{6}\right): \delta 170.3,165.7,160.4,160.2,142.9,130.2,130.1,128.8$, $127.9,127.7,124.7,119.1,113.0,51.9,11.9$ ppm. HRMS calcd for $\mathrm{C}_{19} \mathrm{H}_{17} \mathrm{~N}_{2} \mathrm{O}_{4}[\mathrm{M}+\mathrm{H}]^{+}$, 377.1188; found, 377.1189.

4-(5-Methyl-3-phenylisoxazole-4-carboxamido)benzoic Acid (12). Methyl 4-(5-methyl-3-phenylisoxazole-4-carboxamido)benzoate $11(0.500 \mathrm{~g}, 1.49 \mathrm{mmol})$ was dissolved in an equimixture of THF, methanol, and water $(9 \mathrm{~mL})$. Lithium hydroxide hydrate $(81.1 \mathrm{mg}$, $1.93 \mathrm{mmol}$ ) was added, and the reaction mixture was stirred for $2 \mathrm{~d}$ at room temperature. Diethyl ether was added, and the organic phase was extracted twice with water and once with brine. The combined aqueous phases were acidified with a $1 \mathrm{M}$ solution of in $\mathrm{H}_{2} \mathrm{O}$ and extracted with ethyl acetate. The organic phase was washed four times with water until the aqueous phase remained neutral. Evaporation of the organic phase with a rotary evaporator and drying in vacuo gave compound 12 (464 mg, $1.44 \mathrm{mmol}, 97 \%)$ as a white solid. Mp 217.0$219.0{ }^{\circ} \mathrm{C}$ (decomp.). ${ }^{1} \mathrm{H}$ NMR (300 MHz, DMSO- $\left.d_{6}\right): \delta 12.74$ (bs, $1 \mathrm{H}), 10.70(\mathrm{~s}, 1 \mathrm{H}), 7.93\left(\mathrm{~m}_{\mathrm{c}}, 2 \mathrm{H}\right), 7.77-7.65(\mathrm{~m}, 4 \mathrm{H}), 7.53-7.45$ $(\mathrm{m}, 3 \mathrm{H}), 2.60(\mathrm{~s}, 3 \mathrm{H}) \mathrm{ppm} .{ }^{13} \mathrm{C}$ NMR $\left(75 \mathrm{MHz}, \mathrm{DMSO}-d_{6}\right): \delta 170.7$, $167.3,160.8,160.7,143.0,130.8,130.6,129.3,128.4,128.2,126.5$, 119.5, 113.6, 12.4 ppm. HRMS calcd for $\mathrm{C}_{18} \mathrm{H}_{15} \mathrm{~N}_{2} \mathrm{O}_{4}[\mathrm{M}+\mathrm{H}]^{+}$, 323.1032; found, 323.1032 .

N-(4-Ethynylphenyl)-5-methyl-3-phenylisoxazole-4-carboxamide (15). 5-Methyl-3-phenyl- $N$-[4-[(trimethylsilyl)ethynyl] phenyl]isoxazole-4-carboxamide $4 \mathbf{j}(28.9 \mathrm{mg}, 0.0772 \mathrm{mmol})$ was dissolved under argon in THF $(1 \mathrm{~mL})$. tert-Butyl bromide $(44.5 \mu \mathrm{L}, 0.386$ mmol, 5 equiv) and a $1.0 \mathrm{M}$ solution of tetra- $n$-butylammonium fluoride in THF $(77.2 \mu \mathrm{L}, 0.0772 \mathrm{mmol})$ were added, and the reaction mixture was stirred overnight at room temperature. The solution was diluted with ethyl acetate and washed three times with water. The solvent was removed with a rotary evaporator, and the crude product was purified by automated chromatography on silica gel, using a gradient of increasing ethyl acetate starting with $100 \% n$ hexane to give 15 as a white solid (21.1 mg, $0.0698 \mathrm{mmol}, 90 \%)$. Mp 148.1-150.0 ${ }^{\circ} \mathrm{C} .{ }^{1} \mathrm{H}$ NMR (300 MHz, DMSO- $\left.d_{6}\right): \delta 10.58(\mathrm{~s}, 1 \mathrm{H})$, 7.72-7.60 (m, 4H), 7.53-7.41 (m, 5H), $4.01(\mathrm{~s}, 1 \mathrm{H}), 2.58(\mathrm{~s}, 3 \mathrm{H})$ ppm. ${ }^{13} \mathrm{C}$ NMR $\left(75 \mathrm{MHz}\right.$, DMSO-d $\left.d_{6}\right): \delta 170.1,160.2,160.1,139.0$, 132.4, 130.1, 128.8, 127.9, 127.7, 119.5, 117.0, 113.1, 83.3, 80.1, 11.9 ppm. HRMS calcd for $\mathrm{C}_{19} \mathrm{H}_{15} \mathrm{~N}_{2} \mathrm{O}_{2}[\mathrm{M}+\mathrm{H}]^{+}, 303.1134$; found, 303.1135 .

$\mathrm{N}$-[4-(Diethylamino)phenyl]- $\mathrm{N}$-[(5-methyl-3-phenylisoxazol-4yl)methyl]acetamide (16). $N^{1}, N^{1}$-Diethyl- $N^{4}$-[(5-methyl-3-phenylisoxazol-4-yl)methyl]benzene-1,4-diamine $20(26.9 \mathrm{mg}, \quad 0.0802$ $\mathrm{mmol}$ ) was dissolved under argon in absolute pyridine $(0.50 \mathrm{~mL})$. Acetyl chloride $(7.40 \mu \mathrm{L}, 0.104 \mathrm{mmol}, 1.3$ equiv) was added, and the reaction mixture was shaken in a sealed tube at room temperature for $4 \mathrm{~d}$. Diethyl ether was added, and the organic phase was washed three times with water. The solvent was removed with a rotary evaporator, and the crude product was subjected to automated preparative chromatography. The chromatography on silica gel with an increasing gradient of ethyl acetate in $n$-hexane, starting with $0 \%$ of the ethyl acetate, gave compound $16(27.3 \mathrm{mg}, 0.0723 \mathrm{mmol}, 90 \%)$ as a colorless oil. ${ }^{1} \mathrm{H}$ NMR $\left(300 \mathrm{MHz}, \mathrm{CDCl}_{3}\right): \delta 7.37-7.27(\mathrm{~m}, 5 \mathrm{H})$, $6.57\left(\mathrm{~m}_{\mathrm{c}}, 2 \mathrm{H}\right), 6.41\left(\mathrm{~m}_{\mathrm{c}}, 2 \mathrm{H}\right), 4.81(\mathrm{~s}, 2 \mathrm{H}), 3.30\left(\mathrm{q}, 4 \mathrm{H},{ }^{3} \mathrm{~J}=7.1 \mathrm{~Hz}\right)$, 2.27, 1.79 (each s, each $3 \mathrm{H}), 1.14\left(\mathrm{t}, 6 \mathrm{H},{ }^{3} \mathrm{~J}=7.1 \mathrm{~Hz}\right) \mathrm{ppm} .{ }^{13} \mathrm{C}$ NMR $\left(75 \mathrm{MHz}, \mathrm{CDCl}_{3}\right): \delta 171.3,169.5,162.9,147.4,129.3,129.3,129.2$, $128.8,128.5,128.3,111.9,110.0,44.5,39.9,22.7,12.6,11.3$ ppm. HRMS calcd for $\mathrm{C}_{23} \mathrm{H}_{28} \mathrm{~N}_{3} \mathrm{O}_{2}[\mathrm{M}+\mathrm{H}]^{+}, 378.2182$; found, 378.2187.

(E)-N $N^{1}, N^{1}$-Diethyl-N $N^{4}-[(5-$ methyl-3-phenylisoxazol-4-yl)methylene]benzene-1,4-diamine (19). Synthesis was done according to general procedure III. Deviating from general procedure III, THF was used as a solvent. 5-Methyl-3-phenylisoxazole-4-carbaldehyde $(0.500 \mathrm{~g}, 2.67 \mathrm{mmol}), \mathrm{N}, \mathrm{N}$-diethyl-p-phenylenediamine 17 (0.444 $\mathrm{mL}, 2.67 \mathrm{mmol}), \mathrm{Na}_{2} \mathrm{SO}_{4}(0.400 \mathrm{~g}, 2.82 \mathrm{mmol}), \mathrm{AcOH}(76.5 \mu \mathrm{L}, 1.34$ mmol, 0.5 equiv), and THF $(2.5 \mathrm{~mL})$. Reaction time: $5 \mathrm{~h}$ at room temperature. Chromatography on silica gel gave compound 5 (501 $\mathrm{mg}, 1.50 \mathrm{mmol}, 56 \%)$ as an orange oil. ${ }^{1} \mathrm{H}$ NMR $(300 \mathrm{MHz}$, DMSO$\left.d_{6}\right): \delta 8.39(\mathrm{~s}, 1 \mathrm{H}), 7.76-7.68(\mathrm{~m}, 2 \mathrm{H}), 7.58-7.51(\mathrm{~m}, 3 \mathrm{H}), 7.13$ $\left(\mathrm{m}_{\mathrm{c}}, 2 \mathrm{H}\right), 6.65\left(\mathrm{~m}_{\mathrm{c}}, 2 \mathrm{H}\right), 3.33\left(\mathrm{q}, 4 \mathrm{H},{ }^{3} \mathrm{~J}=7.0 \mathrm{~Hz}\right), 2.78(\mathrm{~s}, 3 \mathrm{H}), 1.08$ $\left(\mathrm{t}, 6 \mathrm{H},{ }^{3} \mathrm{~J}=7.0 \mathrm{~Hz}\right) \mathrm{ppm} .{ }^{13} \mathrm{C}$ NMR $(75 \mathrm{MHz}$, DMSO-d 6 ): $\delta 170.9$, $161.6,146.5,145.2,139.1,129.9,128.8,128.7,128.1,122.3,112.4$, $111.7,43.8,12.6,12.4$ ppm. HRMS calcd for $\mathrm{C}_{21} \mathrm{H}_{24} \mathrm{~N}_{3} \mathrm{O}[\mathrm{M}+\mathrm{H}]^{+}$, 334.1919; found, 334.1923 .

$N^{1}, N^{1}$-Diethyl-N $N^{4}-[(5-m e t h y l-3-p h e n y l i s o x a z o l-4-y l) m e t h y l]-$ benzene-1,4-diamine (20). (E)- $N^{1}, N^{1}$-Diethyl- $N^{4}$-[(5-methyl-3-phenylisoxazol-4-yl)methylene]benzene-1,4-diamine 19 (181 mg, 0.543 $\mathrm{mmol}$ ) was dissolved in absolute THF $(3.5 \mathrm{~mL})$. Sodium borohydride (51.4 $\mathrm{mg}, 1.36 \mathrm{mmol}, 2.5$ equiv) was added, and the reaction mixture was stirred for $2 \mathrm{~h}$. An additional batch of sodium borohydride (51.4 $\mathrm{mg}$, $1.36 \mathrm{mmol}, 2.5$ equiv) and absolute methanol $(2 \mathrm{~mL})$ were added, and the reaction mixture was stirred overnight at room temperature. The reaction mixture was quenched with a saturated solution of $\mathrm{NaHCO}_{3}$ in $\mathrm{H}_{2} \mathrm{O}(5 \mathrm{~mL})$ and after 20 min diluted with ethyl acetate. The organic phase was washed three times with water. The solvent was removed with a rotary evaporator, and the crude product was subjected to automated preparative chromatography. The chromatography on silica gel with an increasing gradient of ethyl acetate in $n$-hexane, starting with $0 \%$ of ethyl acetate, gave compound 
20 (153 mg, $0.456 \mathrm{mmol}, 84 \%)$ as a yellowish solid. Mp 75.8-77.0 ${ }^{\circ} \mathrm{C} .{ }^{1} \mathrm{H}$ NMR $\left(300 \mathrm{MHz}, \mathrm{DMSO}-d_{6}\right): \delta 7.79-7.71(\mathrm{~m}, 2 \mathrm{H}), 7.52-$ $7.45(\mathrm{~m}, 3 \mathrm{H}), 6.58\left(\mathrm{~m}_{\mathcal{O}} 4 \mathrm{H}\right), 5.13\left(\mathrm{t}, 1 \mathrm{H},{ }^{3} \mathrm{~J}=5.5 \mathrm{~Hz}\right), 3.95\left(\mathrm{~d}, 2 \mathrm{H},{ }^{3} \mathrm{~J}\right.$ $=5.5 \mathrm{~Hz}), 3.13\left(\mathrm{q}, 4 \mathrm{H},{ }^{3} \mathrm{~J}=7.0 \mathrm{~Hz}\right), 2.45(\mathrm{~s}, 3 \mathrm{H}), 0.99\left(\mathrm{t}, 6 \mathrm{H},{ }^{3} \mathrm{~J}=7.0\right.$ $\mathrm{Hz})$ ppm. ${ }^{13} \mathrm{C}$ NMR $\left(75 \mathrm{MHz}\right.$, DMSO- $\left.d_{6}\right): \delta 168.3,161.9,140.5$, 140.2, 129.6, 129.1, 128.8, 127.8, 116.2, 114.0, 111.2, 44.8, 37.0, 12.3, 10.9 ppm. HRMS calcd for $\mathrm{C}_{21} \mathrm{H}_{26} \mathrm{~N}_{3} \mathrm{O}[\mathrm{M}+\mathrm{H}]^{+}$, 336.2076; found, 336.2076.

$\mathrm{N}$-[4-(Diethylamino)phenyl]-5-methyl-3-phenylisoxazole-4-sulfonamide (21). 5-Methyl-3-phenylisoxazole-4-sulfonyl chloride (25.0 $\mathrm{mg}, 0.0970 \mathrm{mmol})$ was dissolved in anhydrous pyridine $(1 \mathrm{~mL})$ and cooled to $0{ }^{\circ} \mathrm{C}$ under argon. $N, N$-Diethyl- $p$-phenylenediamine 17 $(22.6 \mu \mathrm{L}, 0.136 \mathrm{mmol})$ was added. After $30 \mathrm{~min}$, the ice bath was removed, and the reaction mixture was stirred overnight at room temperature. Pyridine was removed by codistillation with toluene ( 3 $\times 10 \mathrm{~mL}$ ) in a rotary evaporator. Automated chromatography on silica gel, using an increasing gradient of ethyl acetate, starting with $100 \% n$-hexane gave compound $21(30.2 \mathrm{mg}, 0.0783 \mathrm{mmol}, 81 \%)$ as a white solid. Mp 101.6-103.1 ${ }^{\circ} \mathrm{C}$ (decomp.). ${ }^{1} \mathrm{H}$ NMR (300 MHz, DMSO- $\left.d_{6}\right): \delta 9.59(\mathrm{~s}, 1 \mathrm{H}), 7.53-7.44(\mathrm{~m}, 1 \mathrm{H}), 7.44-7.37(\mathrm{~m}, 3 \mathrm{H})$, $6.75\left(\mathrm{~m}_{\mathrm{c}}, 2 \mathrm{H}\right), 6.54\left(\mathrm{~m}_{\mathrm{c}}, 2 \mathrm{H}\right), 3.28\left(\mathrm{q}, 4 \mathrm{H},{ }^{3} \mathrm{~J}=7.0 \mathrm{~Hz}\right), 2.45(\mathrm{~s}, 3 \mathrm{H})$, $1.05\left(\mathrm{t}, 6 \mathrm{H},{ }^{3} \mathrm{~J}=7.0 \mathrm{~Hz}\right) \mathrm{ppm} .{ }^{13} \mathrm{C}$ NMR $\left(75 \mathrm{MHz}, \mathrm{DMSO}-d_{6}\right): \delta$ $174.7,160.7,146.6,130.4,129.7,128.5,127.5,126.8,123.5,116.2$, 112.2, 44.2, 13.0, 12.7 ppm. HRMS calcd for $\mathrm{C}_{20} \mathrm{H}_{24} \mathrm{~N}_{3} \mathrm{O}_{3} \mathrm{~S}[\mathrm{M}+\mathrm{H}]^{+}$, 386.1538; found, 386.1540 .

$\mathrm{N}$-[4-(Diethylamino)phenyl]-5-methyl-3-phenylisoxazole-4-carbothioamide (23). Synthesis was done according to general procedure V. $\mathrm{N}$-[4-(Diethylamino)phenyl]-5-methyl-3-phenylisoxazole-4-carboxamide 1 (0.600 g, $1.72 \mathrm{mmol})$, Lawesson's reagent $(417 \mathrm{mg}, 1.03 \mathrm{mmol}, 0.6$ equiv), and toluene $(12 \mathrm{~mL})$. Reaction time: $6 \mathrm{~h}$. Recrystallization from ethyl acetate after chromatography on silica gel gave compound $23(0.220 \mathrm{~g}, 0.602 \mathrm{mmol}, 35 \%)$ as fine yellow needles. Mp 229.5-234.2 ${ }^{\circ} \mathrm{C}$ (decomp.). ${ }^{1} \mathrm{H}$ NMR $(300 \mathrm{MHz}$, DMSO- $\left.d_{6}\right): \delta 11.71(\mathrm{~s}, 1 \mathrm{H}), 7.72-7.65(\mathrm{~m}, 2 \mathrm{H}), 7.60\left(\mathrm{~m}_{\mathrm{c}}, 2 \mathrm{H}\right)$ $7.53-7.43(\mathrm{~m}, 3 \mathrm{H}), 6.65\left(\mathrm{~m}_{\mathrm{c}}, 2 \mathrm{H}\right), 3.34\left(\mathrm{q}, 4 \mathrm{H},{ }^{3} \mathrm{~J}=7.0 \mathrm{~Hz}\right), 2.51(\mathrm{~s}$, $3 \mathrm{H}), 1.08\left(\mathrm{t}, 6 \mathrm{H},{ }^{3} \mathrm{~J}=7.0 \mathrm{~Hz}\right) \mathrm{ppm} .{ }^{13} \mathrm{C}$ NMR $\left(75 \mathrm{MHz}\right.$, DMSO- $\left.d_{6}\right)$ : $\delta 183.9,167.3,158.7,145.8,129.9,128.8,128.2,127.5,127.4,124.1$, 110.7, 109.6, 43.7, 12.4, 11.4 ppm. HRMS calcd for $\mathrm{C}_{21} \mathrm{H}_{24} \mathrm{~N}_{3} \mathrm{OS}[\mathrm{M}$ $+\mathrm{H}]^{+}, 366.1640$; found, 366.1642 .

$N$-[4-(Diethylamino)benzyl]-N,5-dimethyl-3-phenylisoxazol-4amine (30a). A mixture of $N$-[4-(diethylamino)benzyl]-5-methyl-3phenylisoxazol-4-amine $33(29.9 \mathrm{mg}, 0.0891 \mathrm{mmol})$, iodomethane (7.80 $\mu \mathrm{L}, 0.125 \mathrm{mmol}, 1.4$ equiv), and cesium carbonate $(40.7 \mathrm{mg}$, $0.125 \mathrm{mmol}, 1.4$ equiv) in absolute DMF $(0.30 \mathrm{~mL})$ was stirred for 3 $\mathrm{d}$ at room temperature under argon. The reaction mixture was diluted with ethyl acetate and washed three times with water. The solvent was removed with a rotary evaporator, and the crude product was subjected to automated preparative chromatography. The chromatography on silica gel with an increasing gradient of ethyl acetate in $n$ hexane, starting with $0 \%$ of ethyl acetate, gave compound 30a (11.5 $\mathrm{mg}, 0.0329 \mathrm{mmol}, 37 \%)$ as a brownish oil. ${ }^{1} \mathrm{H}$ NMR $(300 \mathrm{MHz}$, $\left.\mathrm{CDCl}_{3}\right): \delta 7.99-7.91(\mathrm{~m}, 2 \mathrm{H}), 7.49-7.40(\mathrm{~m}, 3 \mathrm{H}), 7.00\left(\mathrm{~m}_{\mathrm{c}}, 2 \mathrm{H}\right)$, $6.59\left(\mathrm{~m}_{\mathrm{c}}, 2 \mathrm{H}\right), 3.86(\mathrm{~s}, 2 \mathrm{H}), 3.33\left(\mathrm{q}, 4 \mathrm{H},{ }^{3} \mathrm{~J}=7.0 \mathrm{~Hz}\right), 2.6(\mathrm{~s}, 3 \mathrm{H})$, $2.31(\mathrm{~s}, 3 \mathrm{H}), 1.15\left(\mathrm{t}, 6 \mathrm{H},{ }^{3} \mathrm{~J}=7.1 \mathrm{~Hz}\right) \mathrm{ppm} .{ }^{13} \mathrm{C} \mathrm{NMR}(75 \mathrm{MHz}$, $\left.\mathrm{CDCl}_{3}\right): \delta 162.7,159.8,147.4,130.2,130.0,129.4,128.5,128.2$, $127.5,124.5,111.8,60.2,44.5,40.9,12.7,12.4$ ppm. HRMS calcd for $\mathrm{C}_{22} \mathrm{H}_{28} \mathrm{~N}_{3} \mathrm{O}[\mathrm{M}+\mathrm{H}]^{+}$, 350.2232; found, 350.2236.

(E)-N-[4-(Diethylamino)benzylidene]-5-methyl-3-phenylisoxazol-4-amine (31). Synthesis was done according to general procedure III. 4-(Diethylamino)benzaldehyde $(366 \mathrm{mg}, 2.07 \mathrm{mmol})$, 5-methyl3-phenylisoxazol-4-amine 28 (360 mg, $2.07 \mathrm{mmol}), \mathrm{Na}_{2} \mathrm{SO}_{4}(587 \mathrm{mg}$, $4.13 \mathrm{mmol}, 2$ equiv), acetic acid $(29.6 \mu \mathrm{L}, 0.517 \mathrm{mmol}, 0.25$ equiv), and toluene $(4 \mathrm{~mL})$. Chromatography on silica gel gave compound 31 (514 mg, $1.54 \mathrm{mmol}, 74 \%$ ) as yellowish crystals. Mp $119.7-120.6{ }^{\circ} \mathrm{C}$. ${ }^{1} \mathrm{H}$ NMR $\left(300 \mathrm{MHz}\right.$, DMSO- $\left.d_{6}\right): \delta 8.36(\mathrm{~s}, 1 \mathrm{H}), 7.95-7.87(\mathrm{~m}, 2 \mathrm{H})$, $7.96\left(\mathrm{~m}_{\mathrm{c}}, 2 \mathrm{H}\right), 7.53-7.43(\mathrm{~m}, 3 \mathrm{H}), 6.75\left(\mathrm{~m}_{\mathrm{c}}, 2 \mathrm{H}\right), 3.42\left(\mathrm{q}, 4 \mathrm{H},{ }^{3} \mathrm{~J}=\right.$ $7.0 \mathrm{~Hz}), 2.47(\mathrm{~s}, 3 \mathrm{H}), 1.13(\mathrm{t}, 6 \mathrm{H}) \mathrm{ppm} .{ }^{13} \mathrm{C}$ NMR $(75 \mathrm{MHz}$, DMSO$\left.d_{6}\right): \delta 159.2,157.4,146.5,129.4,129.3,129.0,128.6,127.0,126.1$, 123.2, 111.4, 51.5, 43.6, 12.3, 10.1 ppm. HRMS calcd for $\mathrm{C}_{21} \mathrm{H}_{24} \mathrm{~N}_{3} \mathrm{O}$ $[\mathrm{M}+\mathrm{H}]^{+}$, 334.1919; found, 334.1918.
$\mathrm{N}$-[4-(Diethylamino)benzyl]-5-methyl-3-phenylisoxazol-4-amine (33). To a solution of (E)- $\mathrm{N}$-[4-(diethylamino)benzylidene]-5methyl-3-phenylisoxazol-4-amine $28(0.450 \mathrm{~g}, 1.35 \mathrm{mmol})$ in an equimixture of absolute methanol and absolute THF $(8 \mathrm{~mL})$ was added sodium borohydride $(76.6 \mathrm{mg}, 2.03 \mathrm{mmol})$. The reaction mixture was stirred overnight at room temperature. The second portion of sodium borohydride $(76.6 \mathrm{mg}, 2.03 \mathrm{mmol}$ ) was added, and the reaction mixture was stirred overnight at room temperature. The reaction mixture was diluted with ethyl acetate, and the organic phase was washed three times with an equimixture of water and brine. The solvent was removed with a rotary evaporator, and the crude product was subjected to automated preparative chromatography. The chromatography on silica gel with an increasing gradient of ethyl acetate in $n$-hexane, starting with $0 \%$ of ethyl acetate, gave compound 33 (166 mg, $0.495 \mathrm{mmol}, 37 \%)$ as a yellowish oil. ${ }^{1} \mathrm{H}$ NMR (300 MHz, DMSO- $\left.d_{6}\right): \delta 7.93-7.84(\mathrm{~m}, 2 \mathrm{H}), 7.55-7.44(\mathrm{~m}, 3 \mathrm{H}), 6.94$ $\left(\mathrm{m}_{\mathrm{c}}, 2 \mathrm{H}\right), 6.55\left(\mathrm{~m}_{\mathrm{c}}, 2 \mathrm{H}\right), 4.25\left(\mathrm{t}, 1 \mathrm{H},{ }^{3} \mathrm{~J}=6.8 \mathrm{~Hz}\right), 3.70(\mathrm{~d}, 2 \mathrm{H}), 3.28$ $\left(\mathrm{q}, 4 \mathrm{H},{ }^{3} \mathrm{~J}=7.0 \mathrm{~Hz}\right), 2.18(\mathrm{~s}, 3 \mathrm{H}), 1.04(\mathrm{t}, 6 \mathrm{H}) \mathrm{ppm} .{ }^{13} \mathrm{C}$ NMR $(75$ MHz, DMSO- $\left.d_{6}\right): \delta 159.2,157.4,146.5,129.4,129.3,129.0,128.6$, $127.0,126.1,123.2,111.4,51.5,43.6,12.3,10.1 \mathrm{ppm}$. HRMS calcd for $\mathrm{C}_{21} \mathrm{H}_{26} \mathrm{~N}_{3} \mathrm{O}[\mathrm{M}+\mathrm{H}]^{+}$, 336.2076; found, 336.2076.

1-[4-[(5-Methyl-3-phenylisoxazol-4-yl)methoxy]phenyl]propan1-one (34a). (5-Methyl-3-phenylisoxazol-4-yl)methanol 37 (189 mg, $1.00 \mathrm{mmol}), 4^{\prime}$-hydroxypropiophenone $(0.180 \mathrm{~g}, 1.20 \mathrm{mmol}, 1.2$ equiv), and triphenylphosphine ( $315 \mathrm{mg}, 1.20 \mathrm{mmol}, 1.2$ equiv) were dissolved in anhydrous THF $(4 \mathrm{~mL})$ under argon and cooled to $0{ }^{\circ} \mathrm{C}$ in an ice bath. Diisopropyl azodicarboxylate $(0.236 \mathrm{~mL}, 1.20 \mathrm{mmol}$, 1.2 equiv) was added, and the reaction mixture was stirred overnight, while the temperature was allowed to warm to rt. Diethyl ether was added, the organic phase was washed twice with water, and the organic solvents were removed with a rotary evaporator. The crude product was purified by automated chromatography on silica gel, using a gradient of increasing ethyl acetate starting with $100 \%$ nhexane, followed by recrystallization $\left(\mathrm{MeOH} / \mathrm{H}_{2} \mathrm{O} 10+1\right)$ to give compound 34a (254 mg, $0.790 \mathrm{mmol}, 79 \%)$ as white crystals. Mp 117.7-122.4 ${ }^{\circ} \mathrm{C} .{ }^{1} \mathrm{H}$ NMR (300 MHz, DMSO- $\left.d_{6}\right): \delta 7.95\left(\mathrm{~m}_{\mathrm{c}}, 2 \mathrm{H}\right)$, 7.71-7.64 (m, 2H), 7.52-7.44 (m, 3H, $), 7.11\left(\mathrm{~m}_{\mathrm{c}}, 2 \mathrm{H}\right), 5.08(\mathrm{~s}, 2 \mathrm{H})$, $2.99\left(\mathrm{q}, 2 \mathrm{H},{ }^{3} \mathrm{~J}=7.2 \mathrm{~Hz}\right), 2.54(\mathrm{~s}, 3 \mathrm{H}), 1.07(\mathrm{t}, 3 \mathrm{H}) \mathrm{ppm} .{ }^{13} \mathrm{C}$ NMR $\left(75 \mathrm{MHz}, \mathrm{DMSO}-d_{6}\right): \delta 198.9,170.1,162.1,161.5,130.1,130.1$, $130.0,129.0,128.6,127.8,114.7,109.1,59.3,30.9,10.9,8.3$ ppm. HRMS calcd for $\mathrm{C}_{20} \mathrm{H}_{20} \mathrm{NO}_{3}[\mathrm{M}+\mathrm{H}]^{+}, 322.1443$; found, 322.1443 .

Propyl 4-[(5-Methyl-3-phenylisoxazol-4-yl)methoxy]benzoate (34c). To a mixture of (5-methyl-3-phenylisoxazol-4-yl)methanol 37 $(189 \mathrm{mg}, 1.00 \mathrm{mmol})$, propyl 4-hydroxybenzoate $(216 \mathrm{mg}, 1.20$ mmol, 1.2 equiv), and triphenylphosphine $(315 \mathrm{mg}, 1.20 \mathrm{mmol}, 1.2$ equiv) in anhydrous THF (4 mL) that was cooled to $0{ }^{\circ} \mathrm{C}$ in an ice bath was added diisopropyl azodicarboxylate $(0.236 \mathrm{~mL}, 1.20 \mathrm{mmol}$, 1.2 equiv). The reaction mixture was stirred overnight under argon while the temperature was allowed to warm to rt. Ethyl acetate was added, the organic phase was washed three times with water, and the organic solvent was removed with a rotary evaporator. The crude product was purified by automated chromatography on silica gel, using a gradient of increasing ethyl acetate starting with $100 \%$ nhexane to give compound $34 \mathrm{c}(295 \mathrm{mg}, 0.839 \mathrm{mmol}, 84 \%)$ as a colorless oil. $\mathrm{Mp} 89.1-91.4^{\circ} \mathrm{C} .{ }^{1} \mathrm{H}$ NMR $\left(300 \mathrm{MHz}, \mathrm{CDCl}_{3}\right): \delta 8.03$ $\left(\mathrm{m}_{\mathcal{c}}, 2 \mathrm{H}\right), 7.72-7.64(\mathrm{~m}, 2 \mathrm{H}), 7.48-7.38(\mathrm{~m}, 3 \mathrm{H}), 6.97\left(\mathrm{~m}_{\mathcal{c}}, 2 \mathrm{H}\right)$, $4.91(\mathrm{~s}, 2 \mathrm{H}), 4.27\left(\mathrm{t}, 2 \mathrm{H},{ }^{3} \mathrm{~J}=6.7 \mathrm{~Hz}\right), 2.52(\mathrm{~s}, 3 \mathrm{H}), 1.79\left(\mathrm{~m}_{\mathrm{c}}, 2 \mathrm{H}\right)$, $1.03\left(\mathrm{t}, 3 \mathrm{H},{ }^{3} \mathrm{~J}=7.4 \mathrm{~Hz}\right) \mathrm{ppm} .{ }^{13} \mathrm{C} \mathrm{NMR}\left(75 \mathrm{MHz}, \mathrm{CDCl}_{3}\right): \delta 169.9$, $166.4,162.9,161.9,131.8,130.0,129.1,129.0,128.4,124.0,114.6$, $109.3,66.5,59.8,22.3,11.6,10.7 \mathrm{ppm}$. HRMS calcd for $\mathrm{C}_{21} \mathrm{H}_{22} \mathrm{NO}_{4}$ $[\mathrm{M}+\mathrm{H}]^{+}, 352.1549$; found, 352.1548 .

(rac)-1-[4-[(5-Methyl-3-phenylisoxazol-4-yl)methoxy]phenyl]propan-1-ol (34d). 1-[4-[(5-Methyl-3-phenylisoxazol-4-yl)methoxy]phenyl]propan-1-one 34a $(50.0 \mathrm{mg}, 0.156 \mathrm{mmol})$ was dissolved in ethanol $(0.50 \mathrm{~mL})$. Diethylamine $(0.163 \mathrm{~mL}, 1.56 \mathrm{mmol})$ and sodium borohydride $(7.10 \mathrm{mg}, 0.187 \mathrm{mmol})$ were added, and the reaction mixture was stirred at $35^{\circ} \mathrm{C}$ overnight. The second portion of sodium borohydride $(3.5 \mathrm{mg}, 0.094 \mathrm{mmol})$ was added, and the reaction mixture was stirred at $40{ }^{\circ} \mathrm{C}$ for $2 \mathrm{~d}$. The third portion of sodium borohydride $(7.10 \mathrm{mg}, 0.187 \mathrm{mmol})$ was added, and the reaction 
mixture was stirred at $40{ }^{\circ} \mathrm{C}$ overnight. The reaction mixture was diluted with ethyl acetate and washed three times with water. The solvent was removed with a rotary evaporator, and the crude product was purified by automated preparative chromatography. The chromatography on silica gel with an increasing gradient of ethyl acetate in $n$-hexane, starting with $0 \%$ of ethyl acetate, gave compound 34d (39.4 mg, $0.121 \mathrm{mmol}, 78 \%$ ) as an amorphous white solid. ${ }^{1} \mathrm{H}$ NMR $\left(300 \mathrm{MHz}\right.$, DMSO- $\left.d_{6}\right): \delta 7.74-7.67(\mathrm{~m}, 2 \mathrm{H}), 7.52-7.45(\mathrm{~m}$, $3 \mathrm{H}), 7.23\left(\mathrm{~m}_{\mathrm{c}}, 2 \mathrm{H}\right), 6.94\left(\mathrm{~m}_{\mathrm{c}}, 2 \mathrm{H}\right), 4.97\left(\mathrm{~d}, 1 \mathrm{H},{ }^{3} \mathrm{~J}=4.4 \mathrm{~Hz}\right), 4.94(\mathrm{~s}$, $2 \mathrm{H}), 4.38(\mathrm{~m}, 1 \mathrm{H}), 2.50(\mathrm{~s}, 3 \mathrm{H}), 1.68-1.49(\mathrm{~m}, 2 \mathrm{H}), 0.80\left(\mathrm{t}, 3 \mathrm{H},{ }^{3} J=\right.$ $7.4 \mathrm{~Hz})$ ppm. ${ }^{13} \mathrm{C}$ NMR $\left(75 \mathrm{MHz}\right.$, DMSO- $\left.d_{6}\right): \delta 169.7,162.0,156.5$, 139.9, 129.8, 128.9, 128.6, 127.7, 126.9, 114.5, 109.5, 73.1, 59.0, 31.9, 10.8, 10.0 ppm. HRMS calcd for $\mathrm{C}_{20} \mathrm{H}_{22} \mathrm{NO}_{3}[\mathrm{M}+\mathrm{H}]^{+}, 324.1600$; found, 324.1598.

(rac)-4-[[4-(1-Methoxypropyl)phenoxy]methyl]-5-methyl-3-phenylisoxazole (34e). 1-[4-[(5-Methyl-3-phenylisoxazol-4-yl)methoxy]phenyl]propan-1-ol 34d $(25.2 \mathrm{mg}, 0.0780 \mathrm{mmol})$ was dissolved in anhydrous DMF $(0.40 \mathrm{~mL})$ under argon and cooled to $0{ }^{\circ} \mathrm{C}$ in an ice bath. A $60 \%$ dispersion of sodium hydride in mineral oil $(4.7 \mathrm{mg}, 0.12$ mmol, 1.5 equiv) was added. After $45 \mathrm{~min}$, iodomethane $(7.3 \mu \mathrm{L}, 0.12$ mmol, 1.5 equiv) was added. The ice bath was removed, and the reaction mixture was stirred overnight at room temperature. Water and diethyl ether were added, the phases were separated, and the organic phase was washed twice with water. The solvent was removed with a rotary evaporator, and the crude product was purified by automated chromatography on silica gel using a gradient of increasing ethyl acetate, starting with $100 \% n$-hexane to yield compound $34 \mathrm{e}$ (16.9 mg, $0.050 \mathrm{mmol}, 64 \%)$ as a colorless oil. ${ }^{1} \mathrm{H}$ NMR $(300 \mathrm{MHz}$, $\left.\mathrm{CDCl}_{3}\right): \delta 7.82-7.74(\mathrm{~m}, 2 \mathrm{H}), 7.49-7.38(\mathrm{~m}, 3 \mathrm{H}), 7.22\left(\mathrm{~m}_{\mathcal{c}}, 2 \mathrm{H}\right)$, $6.90\left(\mathrm{~m}_{\mathrm{c}}, 2 \mathrm{H}\right), 4.24\left(\mathrm{~d}, 1 \mathrm{H},{ }^{2} \mathrm{~J}=11.6 \mathrm{~Hz}\right),\left(\mathrm{dd}, 1 \mathrm{H},{ }^{3} \mathrm{~J}=6.1 \mathrm{~Hz},{ }^{3} \mathrm{~J}=\right.$ $7.4 \mathrm{~Hz}), 4.09$ (d, $1 \mathrm{H}), 3.83(\mathrm{~s}, 3 \mathrm{H}), 2.33(\mathrm{~s}, 3 \mathrm{H}), 1.94-1.78(\mathrm{~m}, 1 \mathrm{H})$, $1.74-1.59(\mathrm{~m}, 1 \mathrm{H}), 0.88\left(\mathrm{t}, 3 \mathrm{H},{ }^{3} \mathrm{~J}=7.4 \mathrm{~Hz}\right) \mathrm{ppm} .{ }^{13} \mathrm{C}$ NMR $(75$ $\left.\mathrm{MHz}, \mathrm{CDCl}_{3}\right): \delta 169.2,162.9,159.4,134.1,129.6,129.5,128.8$, $128.5,128.2,114.0,110.9,83.1,59.1,55.4,31.2,11.3,10.7 \mathrm{ppm}$. HRMS calcd for $\mathrm{C}_{21} \mathrm{H}_{24} \mathrm{NO}_{3}[\mathrm{M}+\mathrm{H}]^{+}, 338.1756$; found, 338.1756.

2-Cyanoethyl 4-[(5-Methyl-3-phenylisoxazol-4-yl)methoxy]benzoate (35a). Synthesis was done according to general procedure VII. 4-[(5-Methyl-3-phenylisoxazol-4-yl)methoxy] benzoic acid 38 (40.0 mg, $0.129 \mathrm{mmol}$ ), 4-hydroxypropionitrile (26.5 $\mu \mathrm{L}, 0.388$ mmol, 3 equiv), HBTU (73.4 mg, $0.194 \mathrm{mmol}, 1.5$ equiv), DIPEA $(44.9 \mu \mathrm{L}, 0.258 \mathrm{mmol}, 2$ equiv), and DMF $(1.5 \mathrm{~mL})$. Reaction time: 3 d. Solvent for extraction: diethyl ether and a mixture of water and $20 \%$ brine. Chromatography on silica gel gave compound $35 \mathrm{a}(31.2 \mathrm{mg}$, $0.0861 \mathrm{mmol}, 67 \%)$ as a white solid. Mp 109.4-111.1 ${ }^{\circ} \mathrm{C} .{ }^{1} \mathrm{H}$ NMR $\left(300 \mathrm{MHz}, \mathrm{CDCl}_{3}\right): \delta 8.04\left(\mathrm{~m}_{\mathrm{c}}, 2 \mathrm{H}\right), 7.70-7.63(\mathrm{~m}, 2 \mathrm{H}), 7.48-7.39$ $(\mathrm{m}, 3 \mathrm{H}), 6.98\left(\mathrm{~m}_{\mathrm{c}}, 2 \mathrm{H}\right), 4.91(\mathrm{~s}, 2 \mathrm{H}), 4.52\left(\mathrm{t}, 2 \mathrm{H},{ }^{3} \mathrm{~J}=6.3 \mathrm{~Hz}\right), 2.83$ (t, $\left.2 \mathrm{H},{ }^{3} \mathrm{~J}=6.3 \mathrm{~Hz}\right), 2.53(\mathrm{~s}, 3 \mathrm{H}) \mathrm{ppm} .{ }^{13} \mathrm{C} \mathrm{NMR}\left(75 \mathrm{MHz}, \mathrm{CDCl}_{3}\right)$ : $\delta 169.9,165.6,162.9,162.5,132.2,130.0,129.1,129.0,128.4,122.5$, $116.9,114.8,109.2,59.9,59.1,18.4,11.6 \mathrm{ppm}$. HRMS calcd for $\mathrm{C}_{21} \mathrm{H}_{19} \mathrm{~N}_{2} \mathrm{O}_{4}[\mathrm{M}+\mathrm{H}]^{+}, 363.1345$; found, 363.1348.

3-Cyanopropyl 4-[(5-Methyl-3-phenylisoxazol-4-yl)methoxy]benzoate $(35 b)$. Synthesis was done according to general procedure X. 4-[(5-Methyl-3-phenylisoxazol-4-yl)methoxy] benzoic acid $\mathbf{3 8}$ (20.9 mg, $0.0676 \mathrm{mmol}$ ), 4-bromobutanenitrile (20.1 $\mu \mathrm{L}, 0.203$ mmol, 3 equiv), $\mathrm{K}_{2} \mathrm{CO}_{3}$ ( $18.7 \mathrm{mg}, 0.135 \mathrm{mmol}, 2$ equiv), and $\mathrm{DMF}$ ( 1 $\mathrm{mL})$. Reaction time: 4 d. Chromatography on silica gel gave compound 35b (26.7 mg, $0.0699 \mathrm{mmol}$, quant.) as a colorless oil. ${ }^{1} \mathrm{H}$ NMR (300 MHz, DMSO- $\left.d_{6}\right): \delta 7.97\left(\mathrm{~m}_{\mathcal{c}} 2 \mathrm{H}\right), 7.71-7.64(\mathrm{~m}$, $2 \mathrm{H}), 7.53-7.44(\mathrm{~m}, 3 \mathrm{H}), 7.12\left(\mathrm{~m}_{c}, 2 \mathrm{H}\right), 5.09(\mathrm{~s}, 2 \mathrm{H}), 4.30\left(\mathrm{t}, 2 \mathrm{H},{ }^{3} \mathrm{~J}\right.$ $=6.3 \mathrm{~Hz}), 2.67\left(\mathrm{t}, 2 \mathrm{H},{ }^{3} \mathrm{~J}=7.0 \mathrm{~Hz}\right), 2.54(\mathrm{~s}, 3 \mathrm{H}), 2.07-1.97(\mathrm{~m}, 2 \mathrm{H})$ ppm. ${ }^{13} \mathrm{C}$ NMR (75 MHz, DMSO- $\left.d_{6}\right): \delta 170.1,165.2,162.0,161.8$, $131.4,129.9,129.0,128.5,127.8,122.3,120.3,114.8,109.1,63.0$, 59.3, 24.3, 13.6, 10.8 ppm. HRMS calcd for $\mathrm{C}_{22} \mathrm{H}_{21} \mathrm{~N}_{2} \mathrm{O}_{4}[\mathrm{M}+\mathrm{H}]^{+}$, 377.1501; found, 377.1505 .

(5-Methyl-3-phenylisoxazol-4-yl)methanol (37). 5-Methyl-3-phenylisoxazole-4-carboxylic acid $6(2.03 \mathrm{~g}, 10.0 \mathrm{mmol})$ was dissolved in anhydrous THF $(50 \mathrm{~mL})$ and cooled to $0{ }^{\circ} \mathrm{C}$. A $1 \mathrm{M}$ solution of borane tetrahydrofuran complex in THF $(15 \mathrm{~mL}, 15.0 \mathrm{mmol}, 1.5$ equiv) was added slowly via a syringe. The reaction mixture was stirred at room temperature overnight, and the second portion of a 1
M solution of borane tetrahydrofuran complex in THF $(15 \mathrm{~mL})$ was added. The reaction mixture was stirred at room temperature for $2 \mathrm{~d}$, and the third $15 \mathrm{~mL}$ portion of a $1 \mathrm{M}$ borane tetrahydrofuran complex solution in THF was added in two $7.5 \mathrm{~mL}$ portions at an interval of 7 h. The reaction mixture was stirred for $4 \mathrm{~d}$ and quenched with water $(10 \mathrm{~mL})$. Ethyl acetate was added, and the organic phase was washed twice with an equimixture of water and brine, once with a $2 \mathrm{M}$ solution of sodium hydroxide in $\mathrm{H}_{2} \mathrm{O}$, and three times with water until the water phase remained neutral. The organic solvent was removed with a rotary evaporator, and the crude product was purified by automated chromatography on silica gel, using a gradient of increasing diethyl ether starting with $100 \% n$-hexane to give compound 37 (1.00 g, $5.30 \mathrm{mmol}, 53 \%)$ as a white solid. ${ }^{1} \mathrm{H}$ NMR (300 MHz, DMSO$\left.d_{6}\right): \delta 7.89-7.76(\mathrm{~m}, 2 \mathrm{H}), 7.63-7.24(\mathrm{~m}, 3 \mathrm{H}), 5.21\left(\mathrm{t},{ }^{3} J=5.2 \mathrm{~Hz}\right.$, $1 \mathrm{H}), 4.35\left(\mathrm{~d},{ }^{3} \mathrm{~J}=5.2 \mathrm{~Hz}, 2 \mathrm{H}\right), 2.46(\mathrm{~s}, 3 \mathrm{H}) \mathrm{ppm} .{ }^{13} \mathrm{C}$ NMR $(75$ MHz, DMSO- $\left.d_{6}\right): \delta 168.27,161.88,129.71,129.15,128.90,127.99$, $113.63,51.80,10.83 \mathrm{ppm}$.

4-[(5-Methyl-3-phenylisoxazol-4-yl)methoxy]benzoic Acid (38). A mixture of propyl 4-[(5-methyl-3-phenylisoxazol-4-yl)methoxy]benzoate $34 \mathrm{c}(251 \mathrm{mg}, 0.714 \mathrm{mmol})$ and lithium hydroxide monohydrate ( $45.0 \mathrm{mg}, 1.07 \mathrm{mmol}, 1.5$ equiv) in an equimixture of THF, methanol, and water $(3 \mathrm{~mL})$. The reaction mixture was stirred overnight at room temperature. The reaction mixture was diluted with diethyl ether and transferred to a separatory funnel. Water was added, and the mixture was acidified with $1 \mathrm{M}$ hydrochloric acid. The phases were separated, the organic phase was washed neutral with portions of water, and the solvent was removed with a rotary evaporator. The crude product was recrystallized from $n$-hexane/ethyl acetate $(2: 1)$ to give compound 38 (209 mg, $0.676 \mathrm{mmol}, 94 \%)$ as white crystals. Mp $158.3-159.2{ }^{\circ} \mathrm{C} .{ }^{1} \mathrm{H}$ NMR (300 MHz, DMSO- $\left.d_{6}\right): \delta 12.62(\mathrm{bs}, 1 \mathrm{H})$, $7.90\left(\mathrm{~m}_{\mathrm{c}}, 2 \mathrm{H}\right), 7.71-7.64(\mathrm{~m}, 2 \mathrm{H}), 7.53-7.44(\mathrm{~m}, 3 \mathrm{H}), 7.09\left(\mathrm{~m}_{\mathrm{c}}\right.$ $2 \mathrm{H}), 5.07(\mathrm{~s}, 2 \mathrm{H}), 2.54(\mathrm{~s}, 3 \mathrm{H}) \mathrm{ppm} .{ }^{13} \mathrm{C}$ NMR $(75 \mathrm{MHz}$, DMSO$\left.d_{6}\right): \delta 170.0,166.8,162.0,161.4,131.2,129.8,128.9,128.5,127.7$, 123.6, 114.7, 109.1, 59.2, 10.8 ppm. HRMS calcd for $\mathrm{C}_{18} \mathrm{H}_{16} \mathrm{NO}_{4}[\mathrm{M}$ $+\mathrm{H}]^{+}, 310.1079$; found, 310.1084 .

$\mathrm{N}$-[4-(Diethylamino)phenyl]-3-(4-fluorophenyl)-5-methylisoxazole-4-carboxamide (39d). Synthesis was done according to general procedure I. 5-(4-Fluorophenyl)-3-methylisoxazole-4-carboxylic acid 41d $(52.3 \mathrm{mg}, 0.236 \mathrm{mmol}), \mathrm{N}, \mathrm{N}$-diethyl-p-phenylenediamine 17 (43.2 $\mu \mathrm{L}, 0.0427 \mathrm{mmol}, 1.1$ equiv), HBTU (116 mg, $0.307 \mathrm{mmol}, 1.3$ equiv), DIPEA ( $82.3 \mu \mathrm{L}, 0.061 \mathrm{mmol}, 3$ equiv), and DMF $(2 \mathrm{~mL})$. Solvent for extraction: diethyl ether. Eluent for purification: $n$ heptane/ethyl acetate 9:1. Chromatography on silica gel gave compound 39d $(67.3 \mathrm{mg}, 0.183 \mathrm{mmol}, 77 \%)$ as a white solid. ${ }^{1} \mathrm{H}$ NMR (400 MHz, $\left.\mathrm{CDCl}_{3}\right): \delta 7.75-7.64(\mathrm{~m}, 2 \mathrm{H}), 7.23(\mathrm{t}, J=8.6 \mathrm{~Hz}$, $2 \mathrm{H}), 7.12\left(\mathrm{~m}_{\mathrm{c}} 2 \mathrm{H}\right), 6.88(\mathrm{~s}, 1 \mathrm{H}), 6.59\left(\mathrm{~m}_{\mathrm{c}}, 2 \mathrm{H}\right), 3.31\left(\mathrm{q},{ }^{3} \mathrm{~J}=7.1 \mathrm{~Hz}\right.$, $4 \mathrm{H}), 2.75(\mathrm{~s}, 3 \mathrm{H}), 1.13\left(\mathrm{t},{ }^{3} \mathrm{~J}=7.1 \mathrm{~Hz}, 6 \mathrm{H}\right) \mathrm{ppm} .{ }^{13} \mathrm{C}$ NMR $(101$ $\left.\mathrm{MHz}, \mathrm{CDCl}_{3}\right): \delta 174.4,164.2(\mathrm{~d}, J=251.6 \mathrm{~Hz}), 159.2,145.7,131.3$ $(\mathrm{d}, J=8.7 \mathrm{~Hz}), 125.6,124.3(\mathrm{~d}, J=3.6 \mathrm{~Hz}), 122.2,116.6(\mathrm{~d}, J=21.8$ $\mathrm{Hz}), 112.2,111.8,44.7,13.1,12.6$ ppm. HRMS calcd for $\mathrm{C}_{21} \mathrm{H}_{23} \mathrm{FN}_{3} \mathrm{O}_{2}[\mathrm{M}+\mathrm{H}]^{+}$, 368.1774; found, 368.1776.

3-(2,6-Dichlorophenyl)-N-[4-(diethylamino)phenyl]-5-methylisoxazole-4-carboxamide (39e). Synthesis was done according to general procedure I. 3-(2,6-Dichlorophenyl)-5-methylisoxazole-4carboxylic acid $41 \mathrm{e}(272 \mathrm{mg}, 1.00 \mathrm{mmol}), \mathrm{N}, N$-diethyl-p-phenylenediamine $17(0.166 \mathrm{~mL}, 1.00 \mathrm{mmol})$, HBTU (493 mg, $1.30 \mathrm{mmol}$, 1.3 equiv), DIPEA ( $0.348 \mathrm{~mL}, 2.00 \mathrm{mmol}, 2$ equiv), and DMF (4 $\mathrm{mL})$. Solvent for extraction: diethyl ether. Recrystallization $(\mathrm{MeOH} /$ $\left.\mathrm{H}_{2} \mathrm{O} 20+1\right)$ without chromatography on silica gel gave compound 39e (347 mg, $0.830 \mathrm{mmol}, 83 \%)$ as small white needles. Mp 145.4$146.7^{\circ} \mathrm{C} .{ }^{1} \mathrm{H}$ NMR $\left(300 \mathrm{MHz}, \mathrm{DMSO}-d_{6}\right): \delta 9.71(\mathrm{~s}, 1 \mathrm{H}), 7.62-7.50$ $(\mathrm{m}, 3 \mathrm{H}), 7.30\left(\mathrm{~m}_{\mathrm{c}}, 2 \mathrm{H}\right), 6.59\left(\mathrm{~m}_{\mathrm{c}}, 2 \mathrm{H}\right), 3.28\left(\mathrm{q}, 4 \mathrm{H},{ }^{3} \mathrm{~J}=7.0 \mathrm{~Hz}\right)$, $2.71(\mathrm{~s}, 3 \mathrm{H}), 1.05\left(\mathrm{t}, 6 \mathrm{H},{ }^{3} \mathrm{~J}=7.0 \mathrm{~Hz}\right) \mathrm{ppm} .{ }^{13} \mathrm{C} \mathrm{NMR}(75 \mathrm{MHz}$, DMSO-d $\left.{ }_{6}\right): \delta 169.0,158.1,157.8,144.3,134.4,132.0,128.2,127.2$, $127.1,121.8,114.6,111.7,43.7,12.5,12.3$ ppm. HRMS calcd for $\mathrm{C}_{21} \mathrm{H}_{22} \mathrm{Cl}_{2} \mathrm{~N}_{3} \mathrm{O}_{2}[\mathrm{M}+\mathrm{H}]^{+}$, 418.1089; found, 418.1089.

3-(2,6-Dichloro-3-nitrophenyl)-N-[4-(diethylamino)phenyl]-5methylisoxazole-4-carboxamide (39f). Synthesis was done according to general procedure I. 3-(2,6-Dichloro-3-nitrophenyl)-5-methylisoxazole-4-carboxylic acid $41 \mathrm{f}(75.0 \mathrm{mg}, 0.237 \mathrm{mmol}), N, N$-diethyl-p- 
phenylenediamine $17(39.3 \mu \mathrm{L}, 0.237 \mathrm{mmol}), \mathrm{HBTU}(117 \mathrm{mg}, 0.308$ mmol, 1.3 equiv), DIPEA ( $82.6 \mu \mathrm{L}, 0.474 \mathrm{mmol}, 2$ equiv), and DMF $(1.5 \mathrm{~mL})$. Solvent for extraction: diethyl ether. Recrystallization $\left(\mathrm{MeOH} / \mathrm{H}_{2} \mathrm{O} 20+1\right)$ after chromatography on silica gel gave compound 39f $(75.0 \mathrm{mg}, 0.162 \mathrm{mmol}, 68 \%)$ as orange needles. $\mathrm{Mp}$ 89.7-95.5 ${ }^{\circ} \mathrm{C}$ (decomp.). ${ }^{1} \mathrm{H}$ NMR (300 MHz, DMSO- $\left.d_{6}\right): \delta 9.87(\mathrm{~s}$, $1 \mathrm{H}), 8.27\left(\mathrm{~d}, 1 \mathrm{H},{ }^{3} \mathrm{~J}=8.8 \mathrm{~Hz}\right), 7.92(\mathrm{~d}, 1 \mathrm{H}), 7.30\left(\mathrm{~m}_{\mathrm{c}} 2 \mathrm{H}\right), 6.59\left(\mathrm{~m}_{\mathrm{c}}\right.$ $2 \mathrm{H}), 3.28\left(\mathrm{q}, 4 \mathrm{H},{ }^{3} \mathrm{~J}=7.0 \mathrm{~Hz}\right), 2.75(\mathrm{~s}, 3 \mathrm{H}), 1.04\left(\mathrm{t}, 6 \mathrm{H},{ }^{3} \mathrm{~J}=7.0 \mathrm{~Hz}\right)$ ppm. ${ }^{13} \mathrm{C}$ NMR (75 MHz, DMSO-d $\left.d_{6}\right): \delta 169.9,157.6,157.5,147.23$, $144.5,138.3,129.9,129.5,127.5,126.8,126.7,122.1,114.5,111.7$, 43.8, 12.8, 12.3 ppm. HRMS calcd for $\mathrm{C}_{21} \mathrm{H}_{21} \mathrm{Cl}_{2} \mathrm{~N}_{4} \mathrm{O}_{4}[\mathrm{M}+\mathrm{H}]^{+}$, 463.0940; found, 463.0938 .

3-(2,6-Dichloro-3-nitrophenyl)-5-methylisoxazole-4-carboxylic Acid (41f). 3-(2,6-Dichlorophenyl)-5-methylisoxazole-4-carboxylic acid 41e (136 mg, $0.500 \mathrm{mmol}$ ) was dissolved in conc. sulfuric acid $(1 \mathrm{~mL})$ and cooled to $0{ }^{\circ} \mathrm{C}$ in an ice bath. A $65 \%$ solution of nitric acid in $\mathrm{H}_{2} \mathrm{O}(0.50 \mathrm{~mL})$ was added slowly, and the reaction mixture was stirred at $0{ }^{\circ} \mathrm{C}$ for $45 \mathrm{~min}$ and $2 \mathrm{~h}$ at room temperature. The reaction mixture was cooled in an ice bath, and crushed ice $(50 \mathrm{~mL})$ was added slowly in small portions. Filtration and recrystallization $\left(\mathrm{EtOH} / \mathrm{H}_{2} \mathrm{O} 10+1\right)$ gave the crude compound $41 \mathrm{f}(135 \mathrm{mg}, 0.426$ mmol, $85 \%$ ) as white crystals. ${ }^{1} \mathrm{H}$ NMR (300 MHz, DMSO- $\left.d_{6}\right): \delta$ $13.26(\mathrm{~s}, 1 \mathrm{H}), 8.28\left(\mathrm{~d}, 1 \mathrm{H},{ }^{3} \mathrm{~J}=8.8 \mathrm{~Hz}\right), 7.94(\mathrm{~d}, 1 \mathrm{H}), 2.78(\mathrm{~s}, 3 \mathrm{H})$ ppm. ${ }^{13} \mathrm{C}$ NMR (75 MHz, DMSO- $\left.d_{6}\right): \delta 176.2,161.5,157.6,147.1$, 138.1, 130.2, 129.3, 127.5, 126.5, 109.5, $12.8 \mathrm{ppm}$. HRMS calcd for $\mathrm{C}_{11} \mathrm{H}_{6} \mathrm{Cl}_{2} \mathrm{~N}_{2} \mathrm{O}_{5}[\mathrm{M}+\mathrm{H}]^{+}, 316.9732$; found, 316.9733 .

$\mathrm{N}$-[4-(Diethylamino)phenyl]-3-methyl-5-(4-methyl-1,2,3-thiadiazol-5-yl)isoxazole-4-carboxamide (47c). Synthesis was done according to general procedure I. 3-Methyl-5-(4-methyl-1,2,3-thiadiazol-5yl)isoxazole-4-carboxylic acid $46 \mathrm{c}(50.0 \mathrm{mg}, 0.222 \mathrm{mmol}), \mathrm{N}, \mathrm{N}$ diethyl-p-phenylenediamine hydrochloride, $\mathbf{5 0}(78.6 \mathrm{mg}, 0.392 \mathrm{mmol}$, 1.2 equiv), HBTU (126 mg, $0.333 \mathrm{mmol}, 1.5$ equiv), DIPEA (77.3 $\mu \mathrm{L}, 0.444 \mathrm{mmol}, 2$ equiv), and DMF $(1.5 \mathrm{~mL})$. Solvent for extraction: ethyl acetate. Recrystallization $\left(\mathrm{MeOH} / \mathrm{H}_{2} \mathrm{O} 10+1\right)$ after chromatography on silica gel gave compound $47 \mathrm{c}(49.0 \mathrm{mg}, 0.132$ mmol, 59\%) as dark yellow crystals. Mp 103.1-106.9 ${ }^{\circ} \mathrm{C} .{ }^{1} \mathrm{H}$ NMR $\left(300 \mathrm{MHz}, \mathrm{DMSO}-d_{6}\right): \delta 10.11(\mathrm{~s}, 1 \mathrm{H}), 7.40\left(\mathrm{~m}_{\mathcal{c}}, 2 \mathrm{H}\right), 6.66\left(\mathrm{~m}_{\mathcal{c}}\right.$ $2 \mathrm{H}), 3.31(\mathrm{q}, 4 \mathrm{H}, J=7.0 \mathrm{~Hz}), 2.89(\mathrm{~s}, 3 \mathrm{H}), 2.47(\mathrm{~s}, 3 \mathrm{H}), 1.07(\mathrm{t}, 6 \mathrm{H}$, $J=7.0 \mathrm{~Hz})$ ppm. ${ }^{13} \mathrm{C}$ NMR $(75 \mathrm{MHz}$, DMSO-d 6 ): $\delta 158.9,158.4$, $157.9,157.8,144.8,134.2,126.3,121.9,117.6,111.7,43.7,13.9,12.3$, $10.3 \mathrm{ppm}$. HRMS calcd for $\mathrm{C}_{18} \mathrm{H}_{22} \mathrm{~N}_{5} \mathrm{O}_{2} \mathrm{~S}[\mathrm{M}+\mathrm{H}]^{+}, 372.1494$; found, 372.1493.

N-[4-(Diethylamino)phenyl]-3-(1H-tetrazol-1-yl)-1H-pyrazole-4carboxamide $(\mathbf{4 7 g})$. Synthesis was done according to general procedure I. 3-(1H-Tetrazol-1-yl)-1H-pyrazole-4-carboxylic acid $46 \mathrm{~g}$ $(21.6 \mathrm{mg}, 0.120 \mathrm{mmol}), \mathrm{N}, N$-diethyl-p-phenylenediamine $17(27.9$ $\mu \mathrm{L}, 0.168 \mathrm{mmol}, 1.4$ equiv), HBTU (59.2 mg, $0.156 \mathrm{mmol}, 1.3$ equiv), DIPEA (20.9 $\mu \mathrm{L}, 0.240 \mathrm{mmol}, 2$ equiv), and DMF ( $1 \mathrm{~mL})$. Solvent for extraction: ethyl acetate and water/brine (2:1). Chromatography on silica gel gave compound $47 \mathrm{~g}(21.7 \mathrm{mg}$, $0.0665 \mathrm{mmol}, 55 \%)$ as a grayish solid. Mp 218.5-225.6 ${ }^{\circ} \mathrm{C}$ (decomp.). ${ }^{1} \mathrm{H}$ NMR (300 MHz, DMSO-d $\left.)_{6}\right): \delta 13.82$ (br s, $\left.1 \mathrm{H}\right)$, $9.84(\mathrm{~s}, 1 \mathrm{H}), 9.76(\mathrm{~s}, 1 \mathrm{H}), 8.63(\mathrm{~s}, 1 \mathrm{H}), 7.35\left(\mathrm{~m}_{\mathcal{c}}, 2 \mathrm{H}\right), 6.62\left(\mathrm{~m}_{\mathcal{c}}\right.$ $2 \mathrm{H}), 3.29\left(\mathrm{q}, 4 \mathrm{H},{ }^{3} \mathrm{~J}=7.0 \mathrm{~Hz}\right), 1.06\left(\mathrm{t}, 6 \mathrm{H},{ }^{3} \mathrm{~J}=7.0 \mathrm{~Hz}\right) \mathrm{ppm} .{ }^{13} \mathrm{C}$ NMR (75 MHz, DMSO- $\left.d_{6}\right): \delta 158.1,145.2,144.4,141.1,131.7$, $126.9,122.0,111.7,111.2,43.7,12.3 \mathrm{ppm}$. HRMS calcd for $\mathrm{C}_{15} \mathrm{H}_{18} \mathrm{~N}_{8} \mathrm{O}[\mathrm{M}+\mathrm{H}]^{+}$, 327.1682; found, 327.1679.

PAINS. All compounds reported in this Article were electronically matched against known pan assay interference (PAINS ${ }^{42}$ ) substructures by using the zinc database ${ }^{43}$ web application (https:// zinc15.docking.org/patterns/home/). Compounds 30a-d, 33, 64, SI43, SI84, SI92, SI94, and SI109 contained anil_di_alk_D structural alert. In addition, compounds SI20, SI95, SI96, and SI97 contained azo_A structural alert. Aggregation of the selected compounds was researched in our previous study, ${ }^{29}$ and none of the tested compounds showed aggregating behavior in assay concentrations.

Experimental Procedures (Biology). Plasmids. The plasmids expressing mouse GATA4 protein, pMT2-GATA4, and empty pMT2 were gifts from D. B. Wilson (Department of Pediatrics, St. Louis
Children's Hospital, St. Louis, MO). ${ }^{44}$ The plasmids expressing mouse NKX2-5 protein, pMT2-NKX2-5, have been described earlier. $^{28}$ The luciferase reporter plasmid used in GATA4-NKX2-5 transcriptional synergy assay and NKX transcriptional assay, pGL3$3 \mathrm{xHA}$, contains three high affinity binding sites for NKX2-5. ${ }^{28}$ The luciferase reporter plasmid used in GATA transcriptional assay, NP112, contains tandem GATA-sites and minimal promoter of rat brain natriuretic peptide (BNP) gene. ${ }^{45}$ The pGL3-BNP luciferase reporter containing $-534 /+4$ bp rat BNP proximal promoter described previously was used in hypertrophy assay. ${ }^{46}$

Luciferase Assays. The primary screening assay of compounds' effect on GATA4-NKX2-5 transcriptional synergy and COS-1 cell culturing has been described earlier. ${ }^{33}$ COS-1 cells do not express endogenous NKX2-5 protein and a very low amount of GATA4 protein $^{28}$ (Kinnunen et al., unpublished observation). Briefly, COS-1 cells were seeded at 14000 cells/well in Isoplate-96 microplates (PerkinElmer, Turku, Finland) and grown overnight. The cells were transfected with the luciferase reporter plasmid pGL3-3xHA $100 \mathrm{ng} /$ well and equal amounts of expression plasmids pMT2-GATA4 and pMT2-NKX2-5 total $50 \mathrm{ng} /$ well. To verify the synergistic effect, the cells were transfected with pMT2-GATA4 or pMT2-NKX2-5 $25 \mathrm{ng} /$ well, and the total DNA concentration was adjusted to $50 \mathrm{ng} /$ well with empty pMT2 plasmid. In NKX2-5 and GATA4 luciferase reporter assays, the cells were transfected with reporter plasmid pGL3-3xHA or NP-112 (100 ng/well) and expression plasmid pMT2NKX2-5 or pMT2-GATA4 (25 ng/well). The ratio of DNA/ transfection reagent (Fugene 6, Promega) was 1:3 in all assays. The transfections were performed in serum and antibiotics free media for 6 h. The cells were treated with compounds or vehicle ( $0.1 \%$ DMSO) for $24 \mathrm{~h}$, and the luminescence was measured using neolite Reporter Gene Assay System (PerkinElmer, Turku, Finland) and Victor2 plate reader (PerkinElmer, Turku, Finland).

Cardiomyocyte Studies. The neonatal rat ventricular myocytes were isolated from 2- to 3-day-old Wistar rats, as described earlier. ${ }^{29,32}$ Rat pups were acquired from the experimental animal facility of the University of Helsinki with an internal use license (KEK17-012). Animals were housed in standard conditions, and their handling and all procedures were carried out in accordance with University of Helsinki institutional guidelines, which conform to the National Research Council (U.S.) Guide for the Care and Use of Laboratory Animals. ${ }^{47}$ The cells were seeded at 50000 cells/well in Isoplate-96 microplates (PerkinElmer, Turku, Finland) and cultured for 18-20 h with Dulbecco's modified Eagle medium (DMEM)/F12 culture medium containing $2.5 \mathrm{mM}$ L-glutamine, supplemented with $100 \mathrm{IU} /$ $\mathrm{mL}$ penicillin-streptomycin and $10 \%$ fetal bovine serum (all from Gibco, Thermo Scientific). Transfections were carried out for $24 \mathrm{~h}$ in serum free media (CSFM; DMEM/F12, $2.5 \mathrm{mg} / \mathrm{mL}$ bovine serum albumin, $1 \mu \mathrm{M}$ insulin, $2.5 \mathrm{mM}$ L-glutamine, $32 \mathrm{nM}$ selenium, $2.8 \mathrm{mM}$ sodium pyruvate, $5.64 \mu \mathrm{g} / \mathrm{mL}$ transferrin, $1 \mathrm{nM} \mathrm{T} 3$, and $100 \mathrm{IU} / \mathrm{mL}$ PS) by using 100 ng of pGL3-BNP luciferase plasmid per well in a 1:3 ratio of DNA/transfection reagent (Fugene 6, Promega). The compounds or the vehicle (0.1\% DMSO) were added to cells in CSFM media and endothelin-1 (E7764, Sigma-Aldrich) $1 \mathrm{~h}$ later. After $24 \mathrm{~h}$, the luminescence was measured as above.

Toxicity Experiments. For toxicity screening, COS-1 cells were cultured in DMEM (Sigma-Aldrich, Steinheim, Germany) supplemented with $10 \%$ fetal bovine serum, $100 \mathrm{U} / \mathrm{mL}$ penicillin, and 100 $\mu \mathrm{g} / \mathrm{mL}$ streptomycin (all from Gibco, Thermo Scientific) at $37{ }^{\circ} \mathrm{C}$ with $5 \% \mathrm{CO}_{2}$. The cells were plated on 96-well plates at 10000 cells/ well and exposed to test compounds at a concentration range of 1-30 $\mu \mathrm{M}$ on the following day. After a 24 -h compound treatment, lactate dehydrogenase (LDH) and 3-(4,5-dimethylthiazol-2-yl)-2,5-diphenyltetrazolium bromide (MTT) assays were carried out as described previously. ${ }^{48}$ Briefly, LDH activity was determined from $50 \mu \mathrm{L}$ samples of cell culture medium, to which $50 \mu \mathrm{L}$ of substrate solution [1.3 $\mathrm{mM} \beta$-nicotinamide-adenine dinucleotide, $660 \mu \mathrm{M}$ iodonitrotetrazolium, $54 \mathrm{mM} \mathrm{L}(+)$-lactic acid, and $280 \mu \mathrm{M}$ phenazine methosulfate in $0.2 \mathrm{M}$ Tris- $\mathrm{HCl}, \mathrm{pH} 8.2$, all from Sigma-Aldrich] was added, and the plate was incubated for $30 \mathrm{~min}$ at room temperature. The reaction was stopped with acetic acid (final 
concentration $333 \mathrm{mM}$ ), and absorbance was measured at $490 \mathrm{~nm}$. The absorbance values of the samples were normalized to maximal LDH release and spontaneous LDH release determined on the same plate. Mitochondrial metabolic activity was quantified by incubating the cells with $0.5 \mathrm{mg} / \mathrm{mL}$ MTT (from Sigma-Aldrich) for $2 \mathrm{~h}$ at $37^{\circ} \mathrm{C}$ with $5 \% \mathrm{CO}_{2}$, whereafter culture medium was removed and formazan crystals were dissolved in DMSO. The absorbance was measured at $550 \mathrm{~nm}$, and absorbance at $650 \mathrm{~nm}$ was subtracted as background.

A selected set of compounds were tested also in the ATP assay by using CellTiter-Glo Luminescent Cell Viability assay (Promega). Subculturing and treatment of COS-1 cells were otherwise performed similar to that in the MTT test, but the final volume of treatment was $200 \mu \mathrm{L}$ per well. Doxorubicin was used as a positive control in the assay. After treatment, the plates were equilibrated at room temperature for $30 \mathrm{~min}$, after which the media was removed and cells were washed with $100 \mu \mathrm{L}$ of PBS. Next, $50 \mu \mathrm{L}$ of fresh media and $50 \mu \mathrm{L}$ of mixed CellTiter Glo Reagent were added to the plate. The contents of the plates were mixed for $2 \mathrm{~min}$, and incubated at room temperature for $15 \mathrm{~min}$. The luminescence was measured with VarioskanTM LUX Multimode Plate Reader (Thermo Fisher Scientific, Waltham, MA) using SkanItTM Software 5.0.

Data Analysis and Statistics. Raw luciferase data were analyzed in Excel, and clear outliers were removed from triplicates by using the Grubb's test. Data analysis was performed using R. ${ }^{49}$ The luciferase data were first normalized on the basis of the combined mean value of controls. For data visualization and creation of figures, the following $\mathrm{R}$ packages were used: ggplot2, cowplot, RColorBrewer, and pheatmap. The heatmaps of the toxicity data were produced with GraphPad Prism 7.00 (GraphPad Software, La Jolla, CA). Statistical significance of luciferase reporter assay data was evaluated by randomized block analysis of variance followed by Dunnett's post hoc test. A probability value of $P<0.05$ was considered statistically significant. Randomized block analysis of variance was used to block batch variation from the analysis. Statistical analysis for luciferase reporter assay data was conducted before normalization to control.

Results from cardiomyocyte experiments are expressed as mean + SD from at least three independent experiments. Data were analyzed using IBM SPSS Statistics 24 software. Levene's test was used to test homogeneity of variances. If the data met the assumptions of the test, one-way ANOVA followed by Tukey HSD post hoc test were carried out; otherwise Welch ANOVA followed by Games-Howell post hoc test were performed. Significance between ET-1 and DMSO samples was analyzed with independent samples Student's $t$ test. Differences at the level of $P<0.05$ were considered statistically significant.

\section{ASSOCIATED CONTENT}

\section{S Supporting Information}

The Supporting Information is available free of charge on the ACS Publications website at DOI: 10.1021/acs.jmedchem.9b01086.

Synthetic procedures and compound characterization; list of commercially obtained compounds; and hierarchical clustering of the activity data (PDF)

Molecular formula strings (CSV)

\section{AUTHOR INFORMATION}

\section{Corresponding Author}

*Phone: +358 50 4151604. E-mail: jari.yli-kauhaluoma@ helsinki.fi.

\section{ORCID $\odot$}

Mika J. Välimäki: 0000-0002-9687-8197

Samuli Auno: 0000-0003-2931-6853

Henri Xhaard: 0000-0002-3000-7858

Jari Yli-Kauhaluoma: 0000-0003-0370-7653

\section{Author Contributions}

M.J., S.M.K., I.B.A., H.R., M.J.V., V.T., G.B.a.G., H.X., and J.Y.$K$. conceived and designed the experiments. M.J., S.M.K., I.B.A., V.T., G.B.a.G., S.A., and T.B. performed the experiments. M.J., S.M.K., and V.T. analyzed the data.

\section{Notes}

The authors declare the following competing financial interest(s): S.M.K., M.J.V., M.J., G.B.a.G., J.Y.-K. and H.R. are inventors in a pending patent application Pharmaceutical compounds (PCT/ FI2017/050661). The authors have no other competing interests to disclose.

\section{ACKNOWLEDGMENTS}

We thank Nina Sipari and Liisa Lappalainen for their expert technical assistance as well as Tuuli Karhu and Sandhya Chakka for help with the toxicity assays. This work was supported by the Business Finland (Finnish Funding Agency for Innovation, Tekes, 3iRegeneration, project 40395/13) and the Academy of Finland (project 266661). We also acknowledge the Drug Discovery and Chemical Biology Network, funded by Biocenter Finland, for providing access to screening instrumentation.

\section{ABBREVIATIONS USED}

ANOVA, analysis of variance; DMEM, Dulbecco's modified Eagle's medium; LDH, lactate hydrogenase; MST, microscale thermophoresis; MTT, 3-(4,5-dimethylthiazol-2-yl)-2,5-diphenyltetrazolium bromide; NKE, NKX2-5 high affinity response element; NMR, nuclear magnetic resonance; PPI, proteinprotein interaction; TF, transcription factor; UPLC, ultra performance liquid chromatography

\section{REFERENCES}

(1) Scott, D. E.; Bayly, A. R.; Abell, C.; Skidmore, J. Small Molecules, Big Targets: Drug Discovery Faces the Protein-Protein Interaction Challenge. Nat. Rev. Drug Discovery 2016, 15 (8), 533550 .

(2) Jin, L.; Wang, W.; Fang, G. Targeting Protein-Protein Interaction by Small Molecules. Annu. Rev. Pharmacol. Toxicol. 2014, 54, 435-456.

(3) Lawson, A. D. G.; MacCoss, M.; Heer, J. P. Importance of Rigidity in Designing Small Molecule Drugs To Tackle ProteinProtein Interactions (PPIs) through Stabilization of Desired Conformers. J. Med. Chem. 2018, 61, 4283-4289.

(4) Vaquerizas, J. M.; Kummerfeld, S. K.; Teichmann, S. A.; Luscombe, N. M. A Census of Human Transcription Factors: Function, Expression and Evolution. Nat. Rev. Genet. 2009, 10 (4), 252-263.

(5) Molkentin, J. D. The Zinc Finger-Containing Transcription Factors GATA-4, -5, and -6: Ubiquitously Expressed Regulators of Tissue-Specific Gene Expression. J. Biol. Chem. 2000, 275 (50), 38949-38952.

(6) Patient, R. K.; McGhee, J. D. The GATA Family (Vertebrates and Invertebrates). Curr. Opin. Genet. Dev. 2002, 12 (4), 416-422.

(7) Pikkarainen, S.; Tokola, H.; Kerkelä, R.; Ruskoaho, H. GATA Transcription Factors in the Developing and Adult Heart. Cardiovasc. Res. 2004, 63 (2), 196-207.

(8) Heikinheimo, M.; Scandrett, J. M.; Wilson, D. B. Localization of Transcription Factor GATA-4 to Regions of the Mouse Embryo Involved in Cardiac Development. Dev. Biol. 1994, 164 (2), 361-373.

(9) Kuo, Chay T.; Morrisey, Edward E.; Anandappa, Roshani; Sigrist, Kirsten; Lu, Min M.; Parmacek, Michael S.; Soudais, Claire; J, M. L. 1. GATA4 Transcription Factor Is Required for Ventral Morphogenesis and Heart Tube Formation. Genes Dev. 1997, 11 (8), 1061-1072. 
(10) Molkentin, J. D.; Lin, Q.; Duncan, S. A.; Olson, E. N. Requirement of the Transcription Factor GATA4 for Heart Tube Formation and Ventral Morphogenesis. Genes Dev. 1997, 11 (8), 1061-1072.

(11) Misra, C.; Chang, S. W.; Basu, M.; Huang, N.; Garg, V. Disruption of Myocardial Gata4 and Tbx5 Results in Defects in Cardiomyocyte Proliferation and Atrioventricular Septation. Hum. Mol. Genet. 2014, 23 (19), 5025-5035.

(12) Garg, V.; Kathiriya, I. S.; Barnes, R.; Schluterman, M. K.; King, I. N.; Butler, C. A.; Rothrock, C. R.; Eapen, R. S.; Hirayama-Yamada, K.; Joo, K.; Matsuoka, R.; Cohen, J. C.; Srivastava, D. GATA4Mutations Cause Human Congenital Heart Defects and Reveal an Interaction with TBX5. Nature 2003, 424 (6947), 443447.

(13) Hautala, N.; Tokola, H.; Luodonpää, M.; Puhakka, J.; Romppanen, H.; Vuolteenaho, O.; Ruskoaho, H. Pressure Overload Increases GATA4 Binding Activity via Endothelin-1. Circulation 2001, 103 (5), 730-735.

(14) Bisping, E.; Ikeda, S.; Kong, S. W.; Tarnavski, O.; Bodyak, N.; McMullen, J. R.; Rajagopal, S.; Son, J. K.; Ma, Q.; Springer, Z.; Kang, P. M.; Izumo, S.; Pu, W. T. Gata4 Is Required for Maintenance of Postnatal Cardiac Function and Protection from Pressure OverloadInduced Heart Failure. Proc. Natl. Acad. Sci. U. S. A. 2006, 103 (39), 14471-14476.

(15) Oka, T.; Maillet, M.; Watt, A. J.; Schwartz, R. J.; Aronow, B. J.; Duncan, S. A.; Molkentin, J. D. Cardiac-Specific Deletion of Gata4 Reveals Its Requirement for Hypertrophy, Compensation, and Myocyte Viability. Circ. Res. 2006, 98 (6), 837-845.

(16) Heineke, J.; Auger-Messier, M.; Xu, J.; Oka, T.; Sargent, M. A.; York, A.; Klevitsky, R.; Vaikunth, S.; Duncan, S. A.; Aronow, B. J.; Robbins, J.; Cromblehol, T. M.; Molkentin, J. D. Cardiomyocyte GATA4 Functions as a Stress-Responsive Regulator of Angiogenesis in the Murine Heart. J. Clin. Invest. 2007, 117 (11), 3198-3210.

(17) Rysä, J.; Tenhunen, O.; Serpi, R.; Soini, Y.; Nemer, M.; Leskinen, H.; Ruskoaho, H. GATA-4 Is an Angiogenic Survival Factor of the Infarcted Heart. Circ.: Heart Failure 2010, 3 (3), 440-450.

(18) Kikuchi, K.; Holdway, J. E.; Werdich, A. a.; Anderson, R. M.; Fang, Y.; Egnaczyk, G. F.; Evans, T.; Macrae, C. a.; Stainier, D. Y. R.; Poss, K. D. Primary Contribution to Zebrafish Heart Regeneration by Gata4(+) Cardiomyocytes. Nature 2010, 464 (7288), 601-605.

(19) Gupta, V.; Gemberling, M.; Karra, R.; Rosenfeld, G. E.; Evans, T.; Poss, K. D. An Injury-Responsive Gata4 Program Shapes the Zebrafish Cardiac Ventricle. Curr. Biol. 2013, 23 (13), 1221-1227.

(20) Mohammadi, M. M.; Kattih, B.; Grund, A.; Froese, N.; KorfKlingebiel, M.; Gigina, A.; Schrameck, U.; Rudat, C.; Liang, Q.; Kispert, A.; Wollert, K. C.; Bauersachs, J.; Heineke, J. The Transcription Factor GATA 4 Promotes Myocardial Regeneration in Neonatal Mice. EMBO Mol. Med. 2017, 11, 1-15.

(21) Ieda, M.; Fu, J.; Delgado-Olguin, P. Direct Reprogramming of Fibroblasts into Functional Cardiomyocytes by Defined Factors. Cell 2010, 142 (3), 375-386.

(22) Qian, L.; Huang, Y.; Spencer, C. I.; Foley, A.; Vedantham, V.; Liu, L.; Conway, S. J.; Fu, J. D.; Srivastava, D. In Vivo Reprogramming of Murine Cardiac Fibroblasts into Induced Cardiomyocytes. Nature 2012, 485 (7400), 593-598.

(23) Reamon-Buettner, S. M.; Borlak, J. NKX2-5: An Update on This Hypermutable Homeodomain Protein and Its Role in Human Congenital Heart Disease (CHD). Hum. Mutat. 2010, 31 (11), $1185-1194$.

(24) Schott, J. J.; Benson, D. W.; Basson, C. T.; Pease, W.; Silberbach, G. M.; Moak, J. P.; Maron, B. J.; Seidman, C. E.; Seidman, J. G. Congenital Heart Disease Caused by Mutations in the Transcription Factor NKX2-5. Science 1998, 281 (5373), 108-111.

(25) Olson, E. Gene Regulatory Networks in the Evolution and Development of the Heart. Science 2006, 313 (5795), 1922-1927.

(26) Durocher, D.; Charron, F. The Cardiac Transcription Factors Nkx2-5 and GATA-4 Are Mutual Cofactors. EMBO J. 1997, 16 (18), $5687-5696$.
(27) Pikkarainen, S.; Tokola, H.; Majalahti-Palviainen, T.; Kerkelä, R.; Hautala, N.; Bhalla, S. S.; Charron, F.; Nemer, M.; Vuolteenaho, O.; Ruskoaho, H. GATA-4 Is a Nuclear Mediator of Mechanical Stretch-Activated Hypertrophic Program. J. Biol. Chem. 2003, 278 (26), 23807-23816.

(28) Kinnunen, S.; Välimäki, M.; Tölli, M.; Wohlfahrt, G.; Darwich, R.; Komati, H.; Nemer, M.; Ruskoaho, H. Nuclear Receptor-Like Structure and Interaction of Congenital Heart Disease-Associated Factors GATA4 and NKX2-5. PLoS One 2015, 10 (12), No. e0144145.

(29) Välimäki, M. J.; Tölli, M. A.; Kinnunen, S. M.; Aro, J.; Serpi, R.; Pohjolainen, L.; Talman, V.; Poso, A.; Ruskoaho, H. J. Discovery of Small Molecules Targeting the Synergy of Cardiac Transcription Factors GATA4 and NKX2-5. J. Med. Chem. 2017, 60 (18), 77817798.

(30) Kinnunen, S.; Tölli, M.; Välimäki, M.; Jumppanen, M.; Boije af Gennäs, G.; Yli-Kauhaluoma, J.; Ruskoaho, H. Isoxazole-amides for treating cardiac diseases. PCT Int. Appl. WO2018/055235 A1, 2018.

(31) Kinnunen, S. M.; Tölli, M.; Välimäki, M. J.; Gao, E.; Szabo, Z.; Rysä, J.; Ferreira, M. P. A.; Ohukainen, P.; Serpi, R.; Correia, A.; Mäkilä, E.; Salonen, J.; Hirvonen, J.; Santos, H. A.; Ruskoaho, H. Cardiac Actions of a Small Molecule Inhibitor Targeting GATA4NKX2-5 Interaction. Sci. Rep. 2018, 8 (1), 4611.

(32) Ferreira, M. P. A.; Ranjan, S.; Kinnunen, S.; Correia, A.; Talman, V.; Mäkilä, E.; Barrios-Lopez, B.; Kemell, M.; Balasubramanian, V.; Salonen, J.; Hirvonen, J.; Ruskoaho, H.; Airaksinen, A. J.; Santos, H. A. Drug-Loaded Multifunctional Nanoparticles Targeted to the Endocardial Layer of the Injured Heart Modulate Hypertrophic Signaling. Small 2017, 13 (33), 1-14.

(33) Karhu, S. T.; Välimäki, M. J.; Jumppanen, M.; Kinnunen, S. M.; Pohjolainen, L.; Leigh, R. S.; Auno, S.; Földes, G.; Boije af Gennäs, G.; Yli-Kauhaluoma, J.; Ruskoaho, H.; Talman, V. Stem Cells Are the Most Sensitive Screening Tool to Identify Toxicity of GATA4Targeted Novel Small-Molecule Compounds. Arch. Toxicol. 2018, 92 (9), 2897-2911.

(34) Leino, T. O.; Baumann, M.; Yli-Kauhaluoma, J.; Baxendale, I. R.; Wallén, E. A. A. Synthesis of 1,3,6-Trisubstituted Azulenes. J. Org. Chem. 2015, 80 (22), 11513-11520.

(35) Mendelsohn, B. A.; Lee, S.; Kim, S.; Teyssier, F.; Aulakh, V. S.; Ciufolini, M. A. Oxidation of Oximes to Nitrile Oxides with Hypervalent Iodine Reagents. Org. Lett. 2009, 11 (7), 1539-1542.

(36) Han, L.; Zhang, B.; Zhu, M.; Yan, J. An Environmentally Benign Synthesis of Isoxazolines and Isoxazoles Mediated by Potassium Chloride in Water. Tetrahedron Lett. 2014, 55 (14), $2308-2311$.

(37) Nguyen, T. B.; Ermolenko, L.; Al-Mourabit, A. Selective Autoxidation of Benzylamines: Application to the Synthesis of Some Nitrogen Heterocycles. Green Chem. 2013, 15 (10), 2713.

(38) Huber, R. G.; Margreiter, M. A.; Fuchs, J. E.; Von Grafenstein, S.; Tautermann, C. S.; Liedl, K. R.; Fox, T. Heteroaromatic $\pi$-Stacking Energy Landscapes. J. Chem. Inf. Model. 2014, 54 (5), 1371-1379.

(39) Beno, B. R.; Yeung, K.-S.; Bartberger, M. D.; Pennington, L. D.; Meanwell, N. a. A Survey of the Role of Noncovalent Sulfur Interactions in Drug Design. J. Med. Chem. 2015, 58 (11), 43834438.

(40) Fleming, F. F.; Yao, L.; Ravikumar, P. C.; Funk, L.; Shook, B. C. Nitrile-Containing Pharmaceuticals: Efficacious Roles of the Nitrile Pharmacophore. J. Med. Chem. 2010, 53 (22), 7902-7917.

(41) Auld, D. S.; Inglese, J. Interferences with Luciferase Reporter Enzymes. In Assay Guidance Manual; Sittampalam, G., Coussens, N., Brimacombe, K., Grossman, A., Arkin, M., Auld, D., Austin, C., Baell, J., Bejcek, B., Chung, T., Dahlin, J., Devanaryan, V., Foley, T., Glicksman, M., Hall, M., Hass, J., Inglese, J., Iversen, P., Kahl, S., Kales, S., Lal-Nag, M., Li, Z., McGee, J., McManus, O., Xu, X., Eds.; Eli Lilly \& Company and the National Center for Advancing Translational Sciences: Bethesda, MD, 2016; Vol. 1, pp 1-14; http:// www.ncbi.nlm.nih.gov/books/NBK374281/ (accessed Aug 10, 2017).

(42) Baell, J. B.; Holloway, G. A. New Substructure Filters for Removal of Pan Assay Interference Compounds (PAINS) from 
Screening Libraries and for Their Exclusion in Bioassays. J. Med. Chem. 2010, 53 (7), 2719-2740.

(43) Sterling, T.; Irwin, J. J. ZINC 15 - Ligand Discovery for Everyone. J. Chem. Inf. Model. 2015, 55 (11), 2324-2337.

(44) Arceci, R. J.; King, A. A. J.; Simon, M. C.; Orkin, S. H.; Wilson ', D. B. Mouse GATA-4: A Retinoic Acid-Inducible GATA-Binding Transcription Factor Expressed in Endodermally Derived Tissues and Heart. Mol. Cell. Biol. 1993, 13 (4), 2235-2246.

(45) Grépin, C.; Dagnino, L.; Robitaille, L.; Haberstroh, L.; Antakly, T.; Nemer, M. A Hormone-Encoding Gene Identifies a Pathway for Cardiac but Not Skeletal Muscle Gene Transcription. Mol. Cell. Biol. 1994, 14 (5), 3115-3129.

(46) Pikkarainen, S.; Kerkelä, R.; Pöntinen, J.; Majalahti-Palviainen, T.; Tokola, H.; Eskelinen, S.; Vuolteenaho, O.; Ruskoaho, H. Decoy Oligonucleotide Characterization of GATA-4 Transcription Factor in Hypertrophic Agonist Induced Responses of Cardiac Myocytes. J. Mol. Med. 2002, 80 (1), 51-60.

(47) National Research Council (US) Committee for the Update of the Guide for the Care and Use of Laboratory Animals, 8th ed.; https:// www.nap.edu/catalog/12910/guide-for-the-care-and-use-oflaboratory-animals-eighth (accessed Apr 18, 2018).

(48) Talman, V.; Tuominen, R. K.; af Gennäs, G. B.; YliKauhaluoma, J.; Ekokoski, E. C1 Domain-Targeted Isophthalate Derivatives Induce Cell Elongation and Cell Cycle Arrest in HeLa Cells. PLoS One 2011, 6 (5), No. e20053.

(49) R Core Team. R: A Language and Environment for Statistical Computing; https://www.r-project.org/. 